\title{
DEGRADABILIDADE RUMINAL DOS COMPONENTES DA FRAÇÃO NITROGENADA E DE CARBOIDRATOS DE SILAGEM DE MILHO, FARELO DE SOJA E SORGO GRÃO, EM BOVINOS DA RAÇA NELORE
}

\section{PAULO ROSSI JUNIOR \\ Zootecnista}

Orientador: Prof. Dr. MÁX LÁZARO VIEIRA BOSE

Dissertação apresentada à Escola Superior de Agricultura "Luiz de Queiroz", da Universidade de São Paulo, para a obtenção do título de Mestre em Agronomia, Área de Concentração: Ciência Animal e Pastagem.

\section{PIRACICABA}

Estado de São Paulo - Brasil

Novembro - 1994 


\section{DEGRADABILIDADE RUMINAL DOS COMPONENTES DA FRAÇÃO NITROGENADA E DE CARBOIDRATOS DE SILAGEM DE MILHO, FARELO DE SOJA E SORGO GRÃO, EM BOVINOS DA RAÇA NELORE}

PAULO ROSSI JUNIOR

Aprovada em: 27/12/94

Comissão julgadora:

Prof. Dr. Máx Lázaro Vieira Bose ESALQ/USP

Prof. Dr. Celso Boin ESALQ/USP

Dr. Aliomar Gabriel da Silva CPPSE/EMBRAPA

Prof. Dr. Máx Lázaro Vieira Bose Orientador 
Aos meus pais

Paulo e Maria José

$E$ aos meus irmãos

Helena, Marta e Marcelo

A gradeço por todo amor $e$

incentivo para chegar até aqui.

A Alessandra

pelo amor e compreensão

durante esta etopa

Dedico. 


\section{AGRADECIMENTOS}

A Deus, por tudo.

Ao Prof. Dr. Máx Lázaro Vieira Bose pela amizade, incentivo, orientação e exemplo profissional transmitidos durante esses anos de convivência.

Ao Prof. Dr. Celso Boin pela oportunidade de trabalho concedida e pela grande ajuda durante toda a condução deste.

Aos pesquisadores da EMBRAPA (CPPSE - São Carlos) Dr. Aliomar Gabriel da Silva e Dr. Ruy da Carvalheira Wanderley pelos ensinamentos técnicos, colaboração na interpretação dos dados e concessão de equipamentos para o início deste trabalho.

Ao Engenheiro Agrônomo Allan Kardec Braga Ramos pela enorme ajuda na análise dos dados.

Ao Valdomiro do CNPSA/EMBRAPA pelos ensinamentos de estatística.

A Roberta Aparecida Carnevalli pela valiosa ajuda durante as análises bromatológicas.

Aos funcionários e estagiários do Clube de Práticas Zootécnicas (CPZ) pela colaboração durante a condução do ensaio experimental.

Aos funcionários do Laboratório de Nutrição Animal do Departamento de Zoologia da ESALQ, Junior, Lázaro e Elaine pelos empréstimos concedidos.

Ao técnico Cláudio (CPPSE-EMBRAPA) pela ajuda no preparo do material experimental.

A Fundação de Amparo à Pesquisa do Estado de São Paulo (FAPESP), pela bolsa de estudos e auxílio a pesquisa concedidos para a execução deste trabalho.

A Anna Cecília Müller Corrêa pela amizade, carinho e por mostrar-me durante todos esses anos o quanto é possível ser melhor, quando nos conhecemos. hoje por mim.

A Aparecida Pereira (in memorian) e Glória Pereira por tudo que fizeram até

A todos que direta ou indiretamente colaboraram na execução deste trabalho. 


\section{SUMÁRIO}

Página

LISTA DE FIGURAS $\ldots \ldots \ldots \ldots \ldots \ldots \ldots$ viii

LISTA DE TABELAS $\ldots \ldots \ldots \ldots \ldots \ldots \ldots \ldots \ldots \ldots$ ix

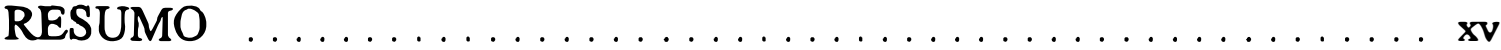

SUMMARY $\ldots \ldots \ldots \ldots \ldots \ldots \ldots \ldots \ldots \ldots \ldots \ldots$ xvii

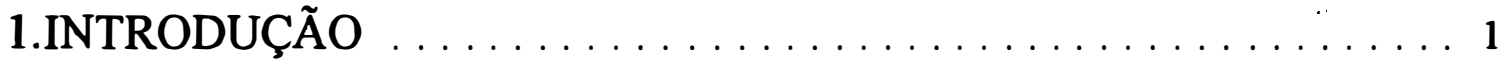

2. REVISÃO DA LITERATURA $\ldots \ldots \ldots \ldots \ldots \ldots$

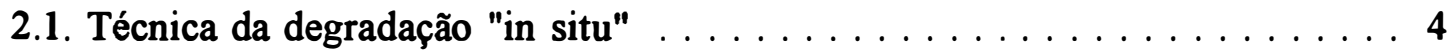

2.1.1. Porosidade do náilon e tamanho de partícula da

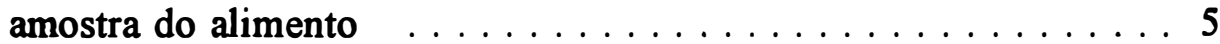

2.1.2. Quantidade de amostra por área livre do saco $\ldots \ldots \ldots \ldots$

2.1.3. Tempos de incubação . . . . . . . . . . . . . . . . . . 10

2.1.4. Efeitos da dieta $\ldots \ldots \ldots \ldots \ldots \ldots \ldots \ldots \ldots$

2.1.5. Outros fatores envolvidos $\ldots \ldots \ldots \ldots \ldots \ldots \ldots$

2.2. Taxa de passagem pelo trato gatrointestinal $\ldots \ldots \ldots \ldots \ldots \ldots$

2.2.1. Fatores que influenciam $\ldots \ldots \ldots \ldots \ldots \ldots \ldots \ldots$

2.3. "Sistema de carboidrato e proteína líquidos

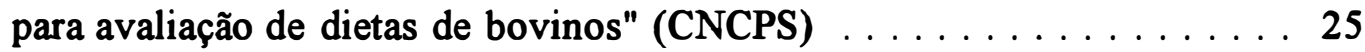

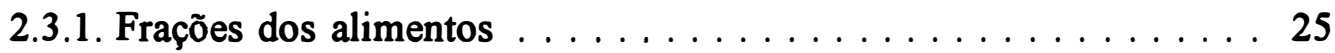

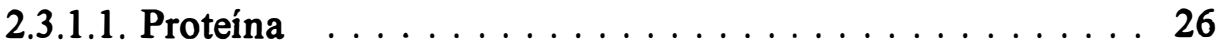

2.3.1.2. Carboidratos . . . . . . . . . . . . . . . . . . . . . . . 29

2.4. Degradação "in situ" de silagem de milho, farelo de soja e sorgo grão. 
3. MATERIAL E MÉTODOS $\ldots \ldots \ldots \ldots \ldots \ldots \ldots \ldots \ldots \ldots \ldots$

3.1. Animais e manejo . . . . . . . . . . . . . . . . . 40

3.2. Dietas utilizadas $\ldots \ldots \ldots \ldots \ldots \ldots \ldots \ldots \ldots \ldots \ldots \ldots \ldots \ldots$

3.3. Obtenção dos alimentos estudados $\ldots \ldots \ldots \ldots \ldots \ldots \ldots \ldots \ldots$

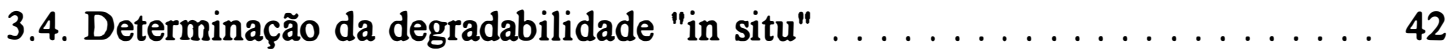

3.4.1. Preparo do material $\ldots \ldots \ldots \ldots \ldots \ldots \ldots \ldots 4$

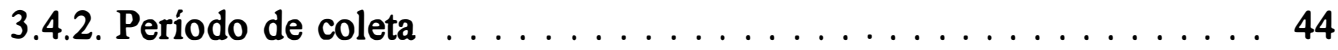

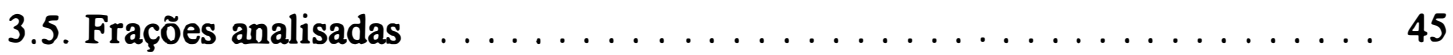

3.6. Determinação das taxas de passagem das dietas . . . . . . . . . . 46

3.7. Análise estatística. $\ldots \ldots \ldots \ldots \ldots \ldots \ldots \ldots \ldots \ldots \ldots \ldots \ldots \ldots \ldots$

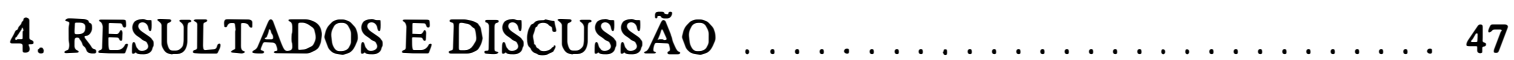

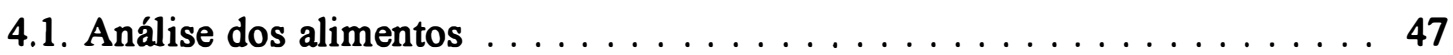

4.1.1. Silagem de milho $\ldots \ldots \ldots \ldots \ldots \ldots \ldots \ldots \ldots$

4.1.2. Farelo de soja $\ldots \ldots \ldots \ldots \ldots \ldots \ldots \ldots \ldots \ldots$

4.1.3. Sorgo grão $\ldots \ldots \ldots \ldots \ldots \ldots \ldots \ldots \ldots \ldots \ldots \ldots$

4.2. Taxa de passagem das dietas $\ldots \ldots \ldots \ldots \ldots \ldots \ldots \ldots$

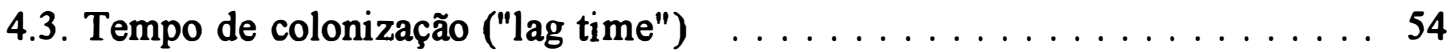

4.4. Frações solúvel, potencialmente degradável, indegradável

e taxa de degradação da fração potencialmente degradável,

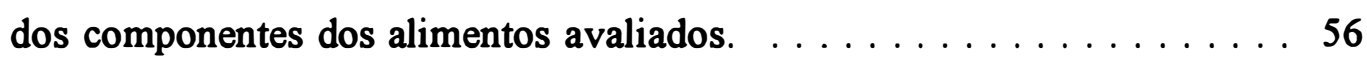

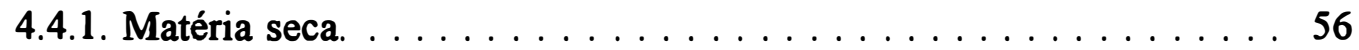

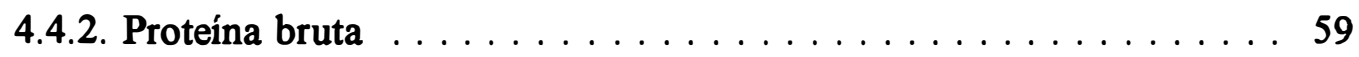

4.4.3. Nitrogênio insolúvel em detergente neutro $\ldots \ldots \ldots \ldots \ldots 2$

4.4.4. Fibra em detergente neutro $\ldots \ldots \ldots \ldots \ldots \ldots \ldots \ldots$

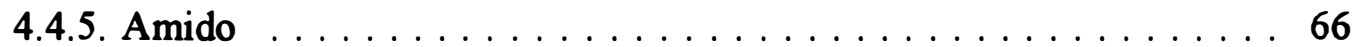


4.5. Degradabilidade potencial e efetiva dos componentes avaliados . . . . . 68

4.5.1. Degradabilidade potencial e efetiva da matéria seca. . . . . . . . 68

4.5.2. Degradabilidade potencial e efetiva da proteína bruta $\ldots \ldots \ldots 71$

4.5.3. Degradabilidade potencial e efetiva do nitrogênio insolúvel em detergente neutro $\ldots \ldots \ldots \ldots \ldots \ldots \ldots 72$

4.5.4. Degradabilidade potencial e efetiva da fibra em

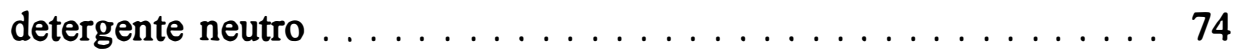

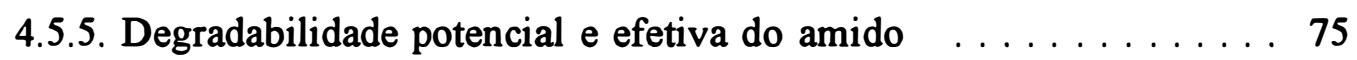

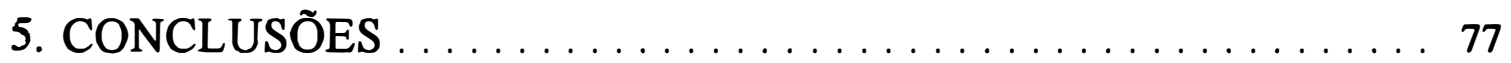

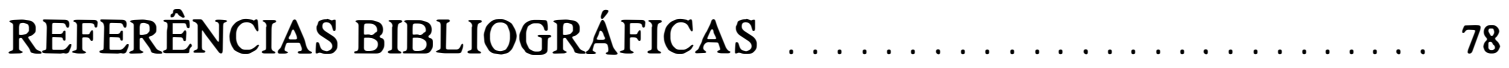

APÊNDICE $\ldots \ldots \ldots \ldots \ldots \ldots \ldots \ldots \ldots \ldots \ldots \ldots \ldots \ldots \ldots \ldots$ 


\section{LISTA DE FIGURAS}

Página

Figura 1. Esquema representativo do fracionamento do nitrogênio dos alimentos

Figura 2. Constituintes nutritivos dos alimentos e relações entre os tipos de carboidratos em alimentos de dietas de ruminantes 


\section{LISTA DE TABELAS}

Página

Tabela 1. Taxas de passagem de concentrados e forragens em dietas com diferentes níveis de concentrado

Tabela 2. Taxas de passagem $(\% / \mathrm{h})$ alimentos assumidas pelo CNCPS para alguns alimentos

Tabela 3. Valores das frações protéicas assumidas pelo CNCPS para alguns alimentos

Tabela 4. Valores das frações de carboidratos assumidas pelo CNCPS para alguns alimentos ................

Tabela 5. Porcentagem de matéria seca, fibra em detergente neutro e proteína bruta solúvel, potencialmente degradável, indegradável e a taxa de degradação da fração potencialmente degradável de silagem de milho com dois níveis de matéria seca

Tabela 6. Coeficientes de degradabilidade, "lag time" e degradabilidade efetiva, da matéria seca, nitrogênio e componentes da fração fibra da silagem de milho

Tabela 7. Frações solúvel, potencialmente degradável, taxa de degradação e degradabilidade efetiva em diferentes taxas de passagem da proteína bruta do sorgo grão e sorgo grão com alto teor de tanino

Tabela 8. Degradabilidade efetiva estimada da matéria seca e proteína bruta, para vacas $7 / 8$ holandês-zebu em diferentes fases . . 
Tabela 9. Degradabilidade efetiva da matéria seca e proteína bruta da silagem de milho, farelo de soja e sorgo grão em diferentes taxas de passagem e estimativas de coeficientes para degradabilidade da proteína bruta (valores médios obtidos de diversos autores)

Tabela 10. Dietas fornecidas aos animais para determinação da degradação "in situ" dos alimentos estudados . . . . . . . .

Tabela 11. Avaliação das dietas fornecidas aos animais segundo o CNCPS (FOX et al.,1990) . . . . . . . . . . . . . . .

Tabela 12. Teores da matéria seca, gordura, cinzas e constituintes das frações protéicas e dos carboidratos da silagem de milho, farelo de soja e sorgo grão

Tabela 13 Taxas de passagem $(\% / h)$ estimadas a partir de amostras de fezes e conteúdo ruminal, nas duas dietas avaliadas . . . . .

Tabela 14. Tempos de colonização ("lag time") da matéria seca obtidos para a silagem de milho, farelo de soja e sorgo grão, nas dietas avaliadas

Tabela 15. Frações solúvel (A), potencialmente degradável (B), indegradável (C) e taxa de degradação da fração potencialmente degradável (c) da matéria seca da silagem de milho, farelo de soja e sorgo grão, nas dietas avaliadas

Tabela 16. Frações solúvel (A), potencialmente degradável (B), indegradável (C) e taxa de degradação da fração potencialmente degradável (c) da proteína bruta da silagem de milho, farelo de soja e sorgo grão, nas dietas avaliadas 
Tabela 17. Frações solúvel (A), potencialmente degradável (B), indegradável (C) e taxa de degradação da fração potencialmente degradável (c) do nitrogênio insolúvel em detergente neutro da silagem de milho e farelo de soja, nas dietas avaliadas

Tabela 18. Frações solúvel (A), potencialmente degradável (B), indegradável (C) e taxa de degradação da fração potencialmente degradável (c) da fibra em detergente neutro da silagem de milho e farelo de soja, nas dietas avaliadas

Tabela 19. Frações solúvel (A), potencialmente degradável (B), indegradável (C) e taxa de degradação da fração potencialmente degradável (c) do amido da silagem de milho, farelo de soja e sorgo grão, nas dietas avaliadas . .

Tabela 20. Degradabilidade potencial e efetiva, com e sem "lag time", da matéria seca da silagem de milho, farelo de soja e sorgo grão, nas dietas avaliadas

Tabela 21. Degradabilidade potencial e efetiva, com e sem "lag time", da proteina bruta da silagem de milho, farelo de soja e sorgo grão, nas dietas avaliadas

Tabela 22. Degradabilidade potencial e efetiva, com e sem "lag time", do nitrogênio insolúvel em detergente neutro da silagem de milho e farelo de soja, nas dietas avaliadas . . . . . . . . .

Tabela 23. Degradabilidade potencial e efetiva, com e sem "lag time", da fibra em detergente neutro da silagem de milho e farelo de soja, nas dietas avaliadas

Tabela 24. Degradabilidade potencial e efetiva, com e sem "lag time", do amido da silagem de milho e sorgo grão, nas dietas avaliadas 
Tabela 25. Frações solúvel (A), potencialmente degradável (B), indegradável (C) e taxa de degradação da fração potencialmente degradável (c) da matéria seca da silagem de milho, farelo de soja e sorgo grão, nas dietas avaliadas. Valores utilizados para calcular a degradabilidade efetiva da matéria seca considerando-se o tempo de colonização ("lag time")

Tabela 26. Frações solúvel (A), potencialmente degradável (B), indegradável (C) e taxa de degradação da fração potencialmente degradável (c) da proteína bruta da silagem de milho, farelo de soja e sorgo grão, nas dietas avaliadas. Valores utilizados para calcular a degradabilidade efetiva da proteína bruta considerando-se o tempo de colonização ("lag time")

Tabela 27. Frações solúvel (A), potencialmente degradável (B), indegradável (C) e taxa de degradação da fração potencialmente degradável (c) da fibra em detergente neutro da silagem de milho e farelo de soja, nas dietas avaliadas. Valores utilizados para calcular a degradabilidade efetiva da fibra em detergente neutro considerando-se o tempo de colonização ("lag time")

Tabela 28. Frações solúvel (A), potencialmente degradável (B), indegradável (C) e taxa de degradação da fração potencialmente degradável (c) do nitrogênio insolúvel em detergente neutro da silagem de milho e farelo de soja, nas dietas avaliadas. Valores utilizados para calcular a degradabilidade efetiva do nitrogênio insolúvel em detergente neutro considerando-se o tempo de colonização ("lag time")

Tabela 29. Frações solúvel (A), potencialmente degradável (B), indegradável (C) e taxa de degradação da fração potencialmente degradável (c) do amido da silagem de milho, farelo de soja e sorgo grão, nas dietas avaliadas. Valores utilizados para calcular a degradabilidade efetiva do amido considerando- se o tempo de colonização

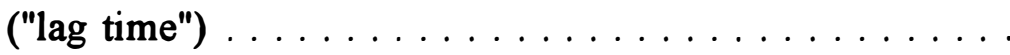


Tabela 30. Degradabilidade efetiva da MS (\%) da silagem de milho, farelo de soja e sorgo grão a diferentes taxas de passagem, em dietas com $80 \%$ de volumoso (Dieta 1) e $60 \%$ volumoso (Dieta 2$) \ldots \ldots \ldots \ldots \ldots \ldots$

Tabela 31. Degradabilidade efetiva da PB (\%) da silagem de milho, farelo de soja e sorgo grão a diferentes taxas de passagem, em dietas com $80 \%$ de volumoso (Dieta 1) e $60 \%$ volumoso (Dieta 2$) \ldots \ldots \ldots \ldots \ldots \ldots$

Tabela 32. Degradabilidade efetiva da FDN (\%) da silagem de milho e farelo de soja a diferentes taxas de passagem, em dietas com $80 \%$ de volumoso (Dieta 1) e $60 \%$ volumoso (Dieta 2)

Tabela 33. Degradabilidade efetiva do NIDN (\%) da silagem de milho e farelo de soja diferentes taxas de passagem, em dietas com $80 \%$ de volumoso (Dieta 1 ) e $60 \%$ volumoso (Dieta 2)

Tabela 34. Degradabilidade efetiva do AM (\%) da silagem de milho e sorgo grão a diferentes taxas de passagem em dietas com $80 \%$ de volumoso (Dieta 1 ) e $60 \%$ volumoso (Dieta 2 ).

Tabela 35. Desaparecimento da MS (\%) da silagem de milho, em diferentes tempos de incubação, nas dietas utilizadas, por animal

Tabela 36. Desaparecimento da MS (\%) do farelo de soja, em diferentes tempos de incubação, nas dietas utilizadas, por animal

Tabela 37. Desaparecimento da MS (\%) do sorgo grão, nos diferentes tempos de incubação, nas dietas utilizadas, por animal . . . 
Tabela 38. Desaparecimento da PB (\%) da silagem de milho, nos diferentes tempos de incubação, nas dietas utilizadas, por animal

Tabela 39. Desaparecimento da PB (\%) do farelo de soja, nos diferentes tempos de incubação, nas dietas utilizadas, por animal .......................

Tabela 40. Desaparecimento da PB (\%) do sorgo grão, nos diferentes tempos de incubação, nas dietas utilizadas, por animal . . .

Tabela 41. Desaparecimento da FDN (\%) da silagem de milho, nos diferentes tempos de incubação, nas dietas utilizadas, por animal

Tabela 42. Desaparecimento da FDN (\%) do farelo de soja, nos diferentes tempos de incubação, nas dietas utilizadas, por animal . . . . . . . . . . . . . . . . . . . . . .

Tabela 43. Desaparecimento do NIDN (\%) da silagem de milho, nos diferentes tempos de incubação, nas dietas utilizadas, por animal

Tabela 44. Desaparecimento do NIDN (\%) do farelo de soja, nos diferentes tempos de incubação, nas dietas utilizadas, por animal

Tabela 45. Desaparecimento do AM (\%) da silagem de milho, nos diferentes tempos de incubação, nas dietas utilizadas, por animal

Tabela 46. Desaparecimento do AM (\%) do farelo de soja, nos diferentes tempos de incubação, nas dietas utilizadas, por animal

Tabela 47. Desaparecimento do AM (\%) do sorgo grão, nos diferentes tempos de incubação, nas dietas utilizadas, por animal . . . 


\title{
DEGRADABILIDADE RUMINAL DOS COMPONENTES DA FRAÇÃO NITROGENADA E DE CARBOIDRATOS DE SILAGEM DE MILHO, FARELO DE SOJA E SORGO GRÃO, EM BOVINOS DA RAÇA NELORE
}

\author{
Autor: PAULO ROSSI JUNIOR \\ Orientador: Prof. Dr. MÁX LÁZARO VIEIRA BOSE
}

\section{RESUMO}

Estudou-se a cinética da degradação dos componentes da fração protéica e dos carboidratos de silagem de milho, farelo de soja e sorgo grão, através do uso da técnica da degradação "in situ", com sacos de náilon, utilizando-se 4 animais nelores com peso médio de $520 \mathrm{~kg}$ e idade aproximada de 36 meses. Avaliou-se a cinética da degradação das frações: proteína bruta, fibra em detergente neutro, nitrogênio insolúvel em detergente neutro e amido, em dietas com 2 níveis de concentrado (20 e $40 \%$ ). 0 volumoso da dieta foi a silagem de milho e o concentrado, farelo de soja e de algodão, milho e sorgo grão. As divisões assumidas para as frações protéicas e de carboidratos seguiram o esquema do "Sistema de carboidratos e proteína líquidos para dietas de bovinos" (CNCPS), proposto por FOX et al. (1990). Empregou-se delineamento em blocos casualizados, onde os animais constituiram os blocos. Através de um esquema fatorial, foi analisado o efeito da dieta sobre os diferentes componentes avaliados, em relação a cada alimento. Observou-se que para a silagem de milho houve boa correspondência entre os valores assumidos pelo modelo de Cornell (CNCPS) e os obtidos neste trabalho, para os componentes da fração proteíca, mas pouca relação com os valores dos componentes da fração carboidrato. Para o farelo de soja e o sorgo grão os valores obtidos foram variáveis, necessitando maior número de dados para sua comprovação. 
$\mathrm{O}$ teor de amido dos alimentos revelou-se inferior aos valores do CNCPS e aos demais dados da literatura, provavelmente devido à metodologia empregada por eles a qual poderia estar superestimando esse componente. As divisões assumidas pelo CNCPS para as frações protéica e carboidratos apresentaram boa relação com os valores provenientes do estudo de degradação "in situ". $O$ efeito de animal ocorrido $(P<0,05)$ para alguns dos parâmetros analisados demonstra a necessidade de maior número de observações para se chegar a valores confiáveis de degradabilidade das frações dos alimentos. $\mathbf{O}$ aumento do nível de concentrado afetou negativamente a silagem de milho e o farelo de soja $(P<0,05)$ e favoreceu o sorgo grão $(P<0,05)$ para alguns dos parâmetros avaliados. O coeficiente de variação elevado, para alguns dos parâmetros analisados, reforça a necessidade de padronização da técnica "in situ" para que os valores obtidos possam ser mais representativos. As taxas de degradação apresentadas pelo CNCPS, diferentes das obtidas neste experimento, para algumas das frações avaliadas, demonstram que maior número de dados são necessários para um ajuste do modelo às nossas condições e nossos alimentos. 

CARBOHYDRATES FRACTIONS IN CORN SILAGE, SOYBEAN MEAL AND SORGHUM GRAIN BY Bos indicus.

Author: PAULO ROSSI JUNIOR

Adviser: Prof. Dr. MÁX LÁZARO VIEIRA BOSE

\section{SUMMARY}

Four Bos indicus (Nelore) rumen fistuladed animals, averanging 36 months of age and $520 \mathrm{~kg}$, were used in a randomized block design to study the ruminal degradability of the nitrogen and carbohydrates fractions of corn silage, soybean meal and sorghum grain. The experimental diets consisted of two levels of concentrate ( 20 and $40 \%$ ), plus corn silage. The concentrate ingredients used were: soybean meal, cotton seed meal, corn grain and sorghum grain. The nitrogen and cabohydrates fractions were analysed according to "The Cornell net carbohydrates and protein system for evaluating cattle diets" (CNCPS). The nitrogen fractions of corn silage were very similar to those published by the Cornell system. However the starch level estimated in this study was smaller than the values proposed by the CNCPS, probably due to different laboratory methods for determining the starch content in feedstuffs. The degradation rates of the several nitrogen and carbohydrates fractions were similar to the values estimated by the CNCPS system. The diets higher in concentrade ( $40 \%)$ showed a lower rate and extent of degradation for corn silage and soybean meal and higher values for sorghum of compared to the diets lower in concentrate $(20 \%)$. 


\section{INTRODUÇÃO.}

A avaliação de alimentos para o arraçoamento dos animais domésticos tem sofrido evolução constante. O "Sistema de Nutrientes Digestíveis Totais" (NDT), criado por. HENRY \& MORRISON em 1915, apesar de ainda largamente utilizado, apresenta inúmeras restrições para predição do valor energético dos diferentes alimentos.

$\mathrm{Na}$ busca de sistemas mais eficientes, ARMSBY em 1917 elaborou o conceito do "Sistema Calórico", que procura determinar a disponibilidade de energia metabolizável e líquida dos alimentos através de sua utilização pelo organismo animal. Apesar de sua eficiência e do grande passo dado para a avaliação de alimentos, trata-se de um sistema dispendioso e difícil de ser executado.

Surgiram posteriormente sistemas mais eficientes para avaliação do valor nutritivo. GOERING \& VAN SOEST (1970) elaboraram um sistema de análise baseado na solubilidade das diferentes frações alimentares em soluções detergentes, o qual sofreu recentemente diversos aperfeiçoamentos (VAN SOEST et al., 1991). MEHREZ \& ORSKOV (1977) basearam-se na degradabilidade das diversas frações dos alimentos, e em 1979 ORSKOV \& Mc DONALD introduziram o efeito da taxa de passagem na avaliação da degradabilidade, lançando o conceito de "degradabilidade efetiva".

Posteriomente os conceitos sobre taxa de passagem e taxa de degradação das fontes de energia e proteína foram amplamente reformulados e considerados imprescindíveis na avaliação de alimentos (Agricultural Research Council-ARC, 1984, National Research Council-NRC, 1985 e 1989). 
O nível de utilização da fração nitrogenada passou a ser considerado importante na avaliação de alimentos e especificação de exigências nutricionais dos ruminantes, visto que a flora rnicrobiana do rúmen possibilita a transformação de nitrogênio não protéico e protéico degradável em proteina microbiana, desde que disponha de energia, predominantemente de carboidratos. A disponibilidade de energia e nitrogênio para os microrganismos é determinada pelas taxas de degradação e de passagem pelo rúmen, e influenciam a eficiência e a quantidade de proteína microbiana sintetizada.

o " Sistema de Carboidratos e Proteina Líquidos para Avaliação de Dietas de Bovinos" (The Cornell Net Carbohydrate and Protein System for Evaluating Cattle DietsCNCPS), desenvolvido na Universidade de Cornell por FOX et al., (1990), surgiu na busca de prever o desempenho animal baseado na composição dos alimentos, taxa de passagem e taxa de degradação das fontes de energia e de nitrogênio, função ruminal, ingestão e exigências nutricionais, procurando integrar os efeitos dos fatores de ambiente e manejo que afetam a ingestão de alimentos, a eficiência ruminal, e a utilização de nutrientes.

Porém, não tem sido considerada a importância dos dados de composição de alimentos e os padrões de resposta animal, que se tem utilizado para estimar exigências nutricionais em sistemas de produção de bovinos, terem sido obtidos sob diferentes condições de exploração dos rebanhos.

Devido a variações na composição química e a diversificação de métodos de análise das frações dos alimentos para a determinação de alguns parâmetros ruminais, torna-se necessário avaliação mais precisa do valor nutritivo dos alimentos, concentrados e volumosos, mais usuais em nosso meio.

As quantidades e proporções dos diversos nutrientes, assim como as taxas de degradação e de passagem pelo rúmen, variam de acordo com a origem e processamento do alimento, determinando quantidades diferentes de nutrientes disponíveis para 0 organismo animal. 
O conhecimento das taxas de degradação e de passagem dos diversos alimentos utilizados em nosso meio poderá fornecer dados mais precisos para o balanceamento de rações mais eficientes.

Para que seja possível a utilização prática de sistemas de avaliação de valor nutritivo como o desenvolvido em Comell (CNCPS, 1990) e os sistemas baseados em proteína degradada e não degradada no rúmen ( ARC, 1984 e NRC, 1989 ), é necessário grande número de observações e confiabilidade dos dados disponíveis. Tratando-se de zebuínos, criados sob condições tropicais, identifica-se enorme lacuna de dados para o balanceamento de rações.

Este trabalho tem como objetivo obter dados referentes às diferentes frações dos alimentos propostas pelo CNCPS, avaliando-se as taxas de degradação das frações nitrogênio total, fibra em detergente neutro, nitrogênio insolúvel em detergente neutro e amido, de silagem de milho, farelo de soja e sorgo grão, em dietas com 2 níveis de concentrado, em animais nelores, afim de se obter dados para posterior utilização em formulação de rações mais eficientes em sistemas de exploração intensiva de bovinos de corte de raça zebuína. 


\section{REVISÃO DA LITERATURA.}

\subsection{Técnica da degradação "in situ".}

A degradação da proteína dos alimentos pode ser estimada pela solubilidade em sais, pelo desaparecimento de compostos nitrogenados em sacos de náilon colocados no rúmen ou no duodeno, através de fístulas em animais (CASTILLO ARIAS, 1992).

Existem diferentes métodos para medir a degradabilidade das proteínas dietéticas e entre estes citam-se: o método de determinação "in vivo", os métodos laboriatorias ("in vitro") e o método "in situ". $\mathrm{O}$ método "in vivo" requer bastante tempo e apresenta custo elevado para ser aplicado rotineiramente (Agricultural and Food Research Council-AFRC, 1987, citado por VALADARES FILHO et al., 1990). Para o ARC (1984), os resultados obtidos "in vivo" somente são aplícáveis para as mesmas condições experimentais (incluindo animais e regime alimentar).

A técnica "in situ" apresenta rapidez e baixo custo (ERASMUS \& PRINSLOO, 1988). Apesar do NRC (1985) considerá-la uma aproximação imperfeita, mostra que ela incorpora efeitos de animal e de microrganismos, sendo útil para determinação da degradabilidade das proteínas no rúmen. $\mathrm{O}$ fato da técnica "in situ" levar em conta a importante dinâmica da interação animal-dieta também é considerado por alguns autores como sua principal vantagem para determinação da degradação da proteína e fíbra dos alimentos, uma vez que o método "in vitro" não consegue reproduzir condições de movimentação do alimento e pH do ambiente como o "in situ" (MERTENS, 1993, PETIT et al., 1994). 
Correlações satisfatórias entre alguns métodos "in vivo" e "in situ" foram encontradas por ROE et al. (1991).

A técnica "in situ" com sacos de náilon foi proposta por MEHREZ \& ORSKOV (1977). É relativamente rápida e a taxa de degradação dos constituintes dos alimentos no rúmen é facilmente determinada, sendo a degradação dos diferentes componentes dos alimentos calculada pela diferença entre as quantidades incubadas e os resíduos.

Conforme adaptações sugeridas por ORSKOV \& McDONALD (1979), o método também permite estimar a degradabilidade efetiva, corrigida pela taxa de passagem.

Apesar de seu uso difundido, não tem sido adotada uma metodologia padrão, pois o número de variáveis que podem afetar os resultados é muito grande, decorrendo daí a necessidade de uma tentativa de uniformização da técnica (ANDRADE, 1994). É fundamental certo padrão de porosidade do náilon utilizado, do tamanho de partícula do alimento, tempo de incubação e dieta dos animais, por constituírem os principais fatores que influenciam sobre os mecanismos de controle do processo, e são necessários para que os valores obtidos sejam reais e utilizáveis.

\subsubsection{Porosidade do náilon e tamanho de partícula da amostra do alimento.}

Estudos procuraram avaliar a porosidade adequada do tecido utilizado na confecção dos sacos que proporcionasse condições para a obtenção de taxas de degradação mais próximas possíveis das reais. A porosidade está associada a natureza de tecido utilizado (dacron ou náilon), que sendo totalmente sintético não sofre qualquer alteração no ambiente ruminal.

WEAKLEY et al. (1983), avaliando a taxa de desaparecimento da matéria seca e do nitrogênio de dietas completas em sacos confeccionados em tecidos com poros de 5 e $53 \mu$ de diâmetro, observaram que houve diferença significativa entre os tecidos avaliados. Principalmente nas primeiras horas de degradação, as dietas incubadas nos sacos de $5 \mu$ apresentaram taxas $50 \%$ menores que as dietas incubadas em sacos de $53 \mu$. 
$O$ autor atenta para o fato de que porosidades até $30 \mu$ impedem o fluxo e refluxo de fluído ruminal nos sacos, bem como leva ao acúmulo de gás no interior destes.

Estudando o desaparecimento da matéria seca e nitrogênio do farelo de soja, NOCEK (1985) comparou sacos confeccionados em tecidos com porosidades de 6, 20, 40, 59, 80 e $102 \mu$ de diâmetro. Os dados obtidos permitem observar que o desaparecimento da matéria seca não diferiu estatísticamente com o aumento da porosidade até $59 \mu$. Entretanto poros de tamanhos superiores proporcionaram aumento pronunciado sobre o desaparecimento da matéria seca. Em relação ao desaparecimento de nitrogênio, este decresceu quando a porosidade aumentou de 6 para $20 \mu$, permaneceu estatisticamente inalterado de 20 a $40 \mu$ e aumentou substancialmente até $102 \mu$. As taxas de desaparecimento tanto da matéria seca como do nitrogênio obtidas nos sacos com porosidades de 40 a $102 \mu$ foram mais coerentes, quando comparadas com dados da literatura.

O fluxo e refluxo de bactérias e protozoários em sacos apresentando diferentes tamanhos de poro foi avaliado por MEYER \& MACKIE (1986). Testando o efeito dos tamanhos de poro $5,10,13,20,30$ e $53 \mu$ de diâmetro, os autores observaram que sacos com as porosidades de 5 e $10 \mu$ apresentaram conteúdo de bactérias no seu interior $30 \%$ inferior ao do rúmen, para animais recebendo feno de alfafa em dietas com alta porcentagem de forragem (75\%). A máxima contagem de bactérias ocorreu em dietas com alta porcentagem de forragem com os sacos apresentando $53 \mu$ de porosidade. A contagem de protozoários para os sacos que apresentaram 30 e $53 \mu$ foi igual ou maior que o conteúdo ruminal, para dietas com feno de alfafa e alta porcentagem de forragem, mas foi menor para dietas com baixo nível de forragem.

A porosidade do saco deve permitir o fluxo do fluído ruminal associado à população microbiana de modo que a degradação do alimento estudado seja efíciente e não permita refluxo de partículas indegradáveis. Desta forma, NOCEK (1988) recomenda a adoção de porosidades de 40 a $60 \mu$ de diâmetro, sendo esta faixa a que reúne as características desejáveis que favorecem o fluxo de fluído ruminal e evita o refluxo de partículas indegradáveis. 
UDEN \& VAN SOEST (1984), citados por NOCEK (1988), mostraram que ocorre acúmulo de gás para porosidade $10 \mu$ de diâmetro, o que estaria impedindo o fluxo de fluído ruminal.

As recomendações mais recentes (Australian Agricultural Council-AAC, 1990) sobre porosidade de tecidos a serem utilizados na confecção de sacos para estudos de degradação " in situ " indicam a faixa de 35 a $50 \mu$ de diâmetro.

TRABALZA MARINUCCI et al. (1992) compararam 2 tipos de tecidos, sendo um com porosidade de $50 \mu$ de diâmetro e $30 \%$ de área livre (50/30) e outro com porosidade de $50 \mu$ de diâmetro e $6 \%$ de área livre (50/6). Os valores de digestibilidade da matéria seca e o desaparecimento de celulose foram maiores para o 50/6 do que para o 50/30, mesmo com sua área livre considerada pequena ( $6 \%$ vs. $30 \%$ ). Isto pode ser atribuído à desuniformidade dos poros do 50/6, que se mostraram variáveis após 48 horas de incubação, em relação ao 50/30. Isto permitiu a saída de partículas, o que é provado quando no tempo 0 horas, sem degradação e somente com lavagem, a digestibilidade da matéria seca e o desaparecimento da celulose são maiores para o 50/6.

Quanto ao tamanho adequado da partícula à degradação microbiana, a literatura consultada mostrou-se muito controvertida.

NOCEK (1988) afirma que a moagem aumenta a superficie por unidade de peso da amostra acessível aos microrganismos e a uniformidade da moagem reflete em menores variações nas taxas de degradação, recomendando para alimentos volumosos 5 mm de tamanho de partícula.

Há recomendações (MEHREZ \& ORSKOV, 1977; AAC,1990) sugerindo que as amostras de alimento volumosos devam ser obtidas através de fístula esofageana, pois o tamanho de partículas obtido pela mastigação seria o mais adequado, ou então que o material seja moído de 1,5 a $2,5 \mathrm{~mm}$ e em seguida peneirado para eliminar partículas mais finas. 
THIAGO (1994) sugere que a forragem não seja moída mas somente cortada em tamanhos médios com aproximadamente $1 \mathrm{~cm}$ de comprimento, procurando-se imitar 0 efeito dos dentes do animal durante o pastejo e a ruminação. $\mathbf{O}$ mesmo procedimento é sugerido por PETIT et al. (1994), devendo as forragens frescas e feno serem picadas em pedaços de $2 \mathrm{~cm}$ para a incubação em sacos de náilon.

Para alimentos concentrados, a recomendação mais indicada parece ser partículas de $2 \mathrm{~mm}$. NOCEK (1988), que em ampla revisão, considerou inconclusiva a literatura quanto à influência do tamanho da partícula sobre a taxa de degradação dos alimentos concentrados e ricos em proteína, recomenda, tamanho de partícula de $2 \mathrm{~mm}$. A mesma recomendaçao é feita pela AAC (1990) e parece ser a adotada na maioria dos trabalhos sobre o assunto (VALADARES FILHO et al., 1991; CASTILLO ARIAS, 1992; TRABALZA MARINUCCI, 1992 ).

Com farelo de soja, WEAKLEY et al.(1983) observaram que a degradação da matéria seca e nitrogênio foi menor com moagem de $2 \mathrm{~mm}$ do que de $0,52 \mathrm{~mm}$. Já NOCEK (1985) não encontrou diferenças na degradação da matéria seca e do nitrogênio do farelo de soja integral ou moído a 1,2 e $5 \mathrm{~mm}$. No entanto, o autor cita que fatores como a lavagem dos sacos antes da incubação possam ter afetado os resultados e contribuído para que os efeitos dos tratamentos não fossem evidentes.

\subsubsection{Quantidade de amostra por área livre do saco.}

A quantidade ideal de amostra a ser incubada deve fornecer resíduo, após a degradação, suficiente para a execução das análises químicas desejadas. Quantidade excessiva prejudica a degradabilidade das frações estudadas, em grande parte devido à compactação do material dentro do saco, impedindo fluxo adequado do fluído ruminal, assim como reduzindo o contato entre as partículas de alimentos e os microrganismos do rúmen (NOCEK, 1988). 
Contudo, a quantidade recomendada é muito variável entre os trabalhos consultados.

NOCEK (1985) recomendou que a quantidade de amostra por área do saco esteja na faixa de 10 a $20 \mathrm{mg} / \mathrm{cm}^{2}$, mesmo não encontrando diferença significativa quando avaliou o efeito de 2,$5 ; 12,5 ; 25,3$ e $37,9 \mathrm{mg} / \mathrm{cm}^{2}$ sobre o desaparecimento da matéria seca e nitrogênio do farelo de soja.

Em sua revisão, NOCEK (1988) cita que UDEN \& VAN SOEST (1974) mostraram que a digestibilidade da parede celular diminuiu de $54 \%$ para $38 \%$ quando a quantidade de amostra foi aumentada de 6,5 para $50 \mathrm{mg} / \mathrm{cm}^{2}$ de superfície do saco de náilon. Estes mesmos autores em trabalho posterior (UDEN \& VAN SOEST,1984, citados por NOCEK, 1988 ) recomendam $6-7 \mathrm{mg} / \mathrm{cm}^{2}$, confirmando a indicação anterior.

VARGA \& HOOVER (1983) compararam dois tamanhos de saco (9 x $17 \mathrm{~cm}$ vs $13 \times 21 \mathrm{~cm})$ e dois pesos de amostra (2,5 e 5,0 g) quanto ao desaparecimento de matéria seca de vários concentrados e forragens, e observaram redução no desaparecimento da matéria seca de 3 a 8 unidades percentuais quando compararam respectivamente 4,6 vs 8,2 e 9,2 vs $16,3 \mathrm{mg} / \mathrm{cm}^{2}$. Os autores citam que após 30 horas de incubação, $5 \mathrm{~g}$ de amostra não proporcionaram resíduo suficiente para a análise de matéria seca e fibra em detergente neutro.

VALADARES FILHO et al. (1991) avaliaram farelo de algodão, trigo, farelo e grão triturado de soja, farinha de peixe, fubá e rolão de milho e feno de.capim colonião, utilizando a proporção de $11 \mathrm{mg} / \mathrm{cm}^{2}$, e sacos de náilon medindo $15 \times 8 \mathrm{~cm}$. Já CASTILLO ARIAS (1992), avaliando os mesmos alimentos, utilizou a proporção de 20 $\mathrm{mg} / \mathrm{cm}^{2}$, e sacos medindo $12 \times 7 \mathrm{~cm}$, no entanto, os resultados quanto à degradação de matéria seca e proteína bruta em ambos trabalhos mostraram-se bem próximos. Outra relação também recomendada por THIAGO (1994) é a de $26 \mathrm{mg} / \mathrm{cm}^{2}$. 


\subsubsection{Tempos de incubação.}

O tempo de incubação depende da natureza do alimento incubado e também apresenta valores variáveis de acordo com cada autor, conforme apresentado a seguir, no quadro 1.

Quadro 1. Tempos de incubação de vários tipos de alimentos em sacos de náilon, no rúmen, segundo diversos autores.

\begin{tabular}{|c|c|c|}
\hline AUTOR & TEMPOS UTILIZADOS & MATERIAL INCUBADO \\
\hline \multirow{3}{*}{$\begin{array}{l}\text { MEHREZ \& ORSKOV (1977) } \\
\text { (recomendações para alcançar o } \\
\text { potencial máx. de degradação) }\end{array}$} & 12 e $36 \mathrm{~h}$ & concentrados \\
\hline & 24 e $60 \mathrm{~h}$ & forragens de alta qualidade \\
\hline & 48 e $72 \mathrm{~h}$ & $\begin{array}{l}\text { forragens de baixa } \\
\text { qualidade }\end{array}$ \\
\hline \multirow{3}{*}{$\begin{array}{l}\text { NOCEK (1988) } \\
\text { (recomendações da revisão feita } \\
\text { pelo autor) }\end{array}$} & 0 a $6 \mathrm{~h}-3$ a 6 intervalos & \multirow{3}{*}{$\begin{array}{l}\text { concentrados e volumosos } \\
\text { de maneira geral. }\end{array}$} \\
\hline & 6 a 24 h -3 a 6 intervalos & \\
\hline & $>25 \mathrm{~h}-6$ a 12 horas de interv. & \\
\hline \multirow{2}{*}{$\begin{array}{l}\text { AAC (1990) } \\
\text { (recomendações) }\end{array}$} & $0,2,4,8,16,24$ e $48 \mathrm{~h}$ & concentrados \\
\hline & $6,12,24,36,48$ e $72 h$ & volumosos \\
\hline $\begin{array}{l}\text { VALADARES FILHO } \\
\text { et al. (1991) }\end{array}$ & $0,4,8,12,16,24$ e $48 \mathrm{~h}$ & silagem de milho e farelos \\
\hline
\end{tabular}

SAMPAIO (1994) sugere, para o estudo da degradação de forrageiras, o intervalo de 6 a 96 horas, e que três ou quatro tempos de incubação estimariam a equação da degradabilidade com a mesma eficiência que sete ou mais tempos. $O$ autor pondera que grande número de tempos de incubação neste intervalo além de aumentar o trabalho experimental interfere no processo digestivo devido à constantes retiradas dos sacos, 0 que certamente ocasionaria elevação do erro experimental e estresse animal. 
O uso de apenas 48 horas de fermentação para estimar o resíduo indigestível pode estar subestimando a fração potencialmente digestível, já que ela é resultado do resíduo degradável menos a fração solúvel e a fração indigestível. MERTENS (1993) afirma que o tempo requerido para que $99 \%$ da digestão seja completada é dado em função do tempo de colonização e da taxa de digestão do alimento. Assim, para resíduos de fibra em detergente neutro com tempo de colonização menor que $6 \mathrm{~h}$ e taxa de digestão maior que $6 \% / \mathrm{h}$, o resíduo indigestível pode ser estimado utilizando-se 72 horas de fermentação, taxa de digestão menor que $6 \% / \mathrm{h}$, o tempo requerido é de 96 horas.

\subsubsection{Efeitos da dieta.}

A dieta é o maior fator determinante da quantidade e tipo de microrganismos no rúmen e, consequentemente, da taxa e extensão de degradação dos nutrientes da dieta (NOCEK , 1988).

As concentrações de proteína e energia das dietas utilizadas nos ensaios de degradação "in situ" tem mostrado efeitos variáveis sobre os resultados.

MERTENS \& LOFTEN (1980), estudando o efeito da adição de amido sobre a cinética da digestão da fração fibra de fenos de alfafa e de costal-bermuda, observaram que a adição do amido resultou em aumento linear no tempo de colonização da fibra, porém a taxa de digestão não foi afetada. Os autores observaram ainda que a extensão da digestão foi reduzida quando o amido foi adicionado.

WEAKLEY et al. (1983) avaliaram o desaparecimento da matéria seca e do nitrogênio do farelo de soja em dietas com $25,40,60$ e $80 \%$ de feno de alfafa. As dietas contendo $25 \%$ de alfafa apresentaram menor desaparecimento de nitrogênio do que as dietas contendo $80 \%$ de alfafa, mas não houve efeito dos níveis de concentrado, quanto à matéria seca. 
FARIA \& HUBER (1984) avaliaram a degradação "in situ" da matéria seca de silagem de milho, feno de alfafa e de gramíneas, em dietas isocalóricas com 3 níveis de proteína $(8,1 ; 11,3$ e 13,3\%) e em dietas com 3 níveis de energia (0,30 e $60 \%$ de milho). Não houve efeito dos diferentes níveis de proteína bem como dos diferentes níveis de energia das dietas sobre o desaparecimento da matéria seca. No entanto para incubação por 24 hs o desaparecimento da matéria seca foi maior para a dieta sem milho do que para 30 e $60 \%$ de milho.

Aumentos na digestibilidade da matéria seca da palha de trigo, feno de alfafa e sorgo grão floculado foram encontrados por POORE (1987), quando o nível de concentrado passou de 30 para $90 \%$, quando sorgo floculado substituiu palha de trigo e feno de alfafa em 30, 60 e $90 \%$. Não houve porém aumento na digestibilidade da fibra em detergente neutro, mas o $\mathrm{pH}$ decresceu com o aumento nos níveis de concentrado.

NOCEK (1988) recomenda que as dietas basais nas quais serão conduzidos os ensaios de degradação "in situ" contenham preferencialmente os mesmos alimentos a serem estudados, e que as proporções entre concentrado e volumoso sejam mantidas de modo que satisfaçam as exigências desejadas para a categoria animal em estudo. $\mathbf{O}$ uso de dietas contendo os mesmos alimentos que estão sendo submetidos a degradação também é recomendado por ANDRADE (1994).

A AAC (1990) recomenda que os estudos de degradação "in situ" sejam conduzidos em dietas com igual proporção entre volumoso e concentrado, e com teor de proteína por volta de $13 \%$ da matéria seca.

Segundo BÜRGER et al. (1990), dietas exclusivas de volumosos podem contribuir para a ocorrência de taxas mais elevadas de degradação do nitrogênio para os tempos iniciais de fermentação dos substratos incubados. Para os autores, esse fato também estaria associado ao incremento na atividade celulolítica dos microrganismos, expondo mais proteína para a ação proteolítica. 
VILELA (1994), citado por VALADARES FILHO (1994), conduziu experimento, com vacas gestantes, para avaliar os efeitos de quatro rações, com dois níveis de concentrados (10 e 40\% na base da matéria seca) e duas formas de volumoso (capimelefante verde ou ensilado), sobre as degradabilidades potenciais da matéria seca e proteína bruta de vários alimentos dentre eles o farelo de soja e algodão, o fubá de milho, o caroço de algodão e o grão de soja moído. Para a degradabilidade potencial da matéria seca e proteína bruta não houve influência das rações sobre os valores observados para nenhum dos alimentos citados.

De maneira geral a degradabilidade do nitrogênio diminui com o aumento da proporção de concentrado das dietas, e a degradabilidade da matéria seca não é afetada. Todavia, o efeito da proporção de concentrado sobre a degradabilidade da proteína varia com os tipos de ingredientes da dieta, segundo PETIT (1994). O aumento no nível de concentrado diminui a degradadilidade da proteína e da fíbra provávelmente devido a um decréscimo no número de bactérias celulolíticas e no $\mathrm{pH}$ ruminal ou pelo aumento na taxa de diluição do rúmen, diminuindo o tempo de exposição da proteína do alimento ao ataque das bactérias proteolíticas.

A redução em número e atividade das bactérias celulolíticas devido à substâncias inibidoras produzidas por bactérias amilolíticas e baixo $\mathrm{pH}$ associada a rápida digestão do amido, já em 1961 eram mencionados por DEHORIT \& JOHNSON, citados por POORE (1987) e aceitos entre outros por HOOVER (1986) como os principais fatores que afetam a digestão da fibra em dietas com altos níveis de concentrado.

\subsubsection{Outros fatores envolvidos.}

Além dos fatores já mencionados, outros devem ser levados em consideração quanto aos seus efeitos sobre os resultados obtidos em ensaios de degradação "in situ". 
Quanto ao efeito animal, a maior parte dos ensaios utiliza bovinos ou ovinos. No entanto, os resultados obtidos não possibilitam comparações devido a fatores inerentes à própria espécie. SIDDONS \& PARADINE (1983), citados por NOCEK (1988), comparando ovinos e bovinos submetidos a dieta de mantença, observaram que ovinos apresentam maior concentração de amônia e menor quantidade de ácidos graxos voláteis no rúmen, porém o $\mathrm{pH}$ e taxa de diluição são similares aos bovinos. $\mathrm{O}$ mesmo autor cita PRIGGE et al. (1984), que encontraram tempo de retenção de sólidos $50 \%$ superior para bovinos em relação a ovinos ( 26 vs. 17,4 horas).

Quando avaliadas dentro da mesma espécie, as principais variações parecem estar relacionadas com o estado fisiológico dos animais em estudo. VALADARES FILHO et al. (1991) avaliaram a degradabilidade da matéria seca e da proteína bruta de vários alimentos para vacas na fase inicial e após o pico de lactação e vacas secas no terço final da gestação. Não foi observado efeito destas fases sobre a degradação das frações estudadas. Contudo, a taxa de passagem de digesta foi significativamente inferior para as vacas no final de gestação, em relação às vacas em lactação.

Outros fatores relacionados com a própria metodologia podem influenciar direta ou indiretamente a taxa de degradação ruminal. A lavagem dos sacos antes da incubação é recomendada por NOCEK (1988), tendo como finalidade remover a fração rapidamente solúvel, assim como o umedecimento do alimento, simulando a salivação. É recomendada a lavagem por 15 minutos em água a $39^{\circ} \mathrm{C}$.

NOCEK (1985), avaliando a degradabilidade da matéria seca e nitrogênio do farelo de soja, concluiu que a lavagem antes da incubação contribui para diminuir variações nos resultados, mas quando se está avaliando os efeitos do grau de moagem da amostra sobre sua degradação, deve-se tomar cuidado, pois pode-se perder boa parte da amostra na pré-lavagem no caso de moagens muito finas.

No entanto, esse procedimento de lavagem nem sempre é adotado ou mencionado em trabalhos que avaliaram a degradabilidade ruminal de alimentos (WEAKLEY et al., 1983; FARIA \& HUBER, 1984; VALADARES FILHO et al., 1991; CASTILLO ARIAS, 1992). 
Outro procedimento que se mostra controvertido na literatura é a sequência de colocação dos sacos no rúmen. NOCEK (1985) comparou os efeitos da colocação simultânea de todos os sacos no rúmen e retirada nos determinados intervalos de tempo com a colocação dos sacos em ordem reversa e retirados de uma só vez. Ele observou menor taxa de desaparecimento de nitrogênio e matéria seca para o farelo de soja quando os sacos foram retirados a cada tempo de incubação. $\mathbf{O}$ autor justifica que a retirada dos sacos a cada intervalo de tempo expõe os outros sacos que serão retirados mais tarde, e com isso é interrompida a fermentação. Além disso, a lavagem parcelada dos sacos após a retirada pode aumentar as variações quando comparadas com a lavagem simultânea que ocorre no outro procedimento.

A AAC (1990) recomenda que os sacos sejam inseridos de uma só vez no rúmen e retiradas duas repetições a cada tempo determinado de incubação. Alguns trabalhos (VALADARES FILHO et al., 1991; CASTILLO ARIAS, 1992) adotaram o procedimento de colocar os sacos de náilon, com as repetições para cada alimento em estudo, dentro de um saco maior tipo rede $(25 \times 30 \mathrm{~cm})$ e inseri-lo de uma só vez no rúmen, retirando um deste para cada tempo de incubação, e não observaram interferência deste procedimento nos resultados obtidos.

Após a retirada dos sacos do rúmen, eles devem ser imediatamente mergulhados em água fria para interromper a fermentação, e em seguida lavados de modo a ser retirado todo o fluído ruminal ainda existente no seu interior. $O$ processo de lavagem pode ser manual ou utilizando-se lavadora de roupas de pequena capacidade. A lavagem manual deve ser feita em água corrente, individualmente, para cada saco, de preferência fria, até o ponto em que a água se torne incolor (aproximadamente 90 segundos/saco). Deve-se evitar esfregar os sacos para que não haja efeito físico sobre a amostra ( AAC, 1990; VALADARES FILHO et al., 1991; CASTILLO ARIAS, 1992). No caso da lavagem à máquina, uma determinada quantidade de sacos é colocada de acordo com o volume de água e submetida a agitação não muito intensa. $\mathbf{O}$ controle do tempo ideal de lavagem pode ser feito observando-se a água de lavagem até que a mesma se torne incolor (NOCEK, 1988). 
CHERNEY et al. (1990) concluíram que a lavagem dos sacos em máquina por 5 minutos superestima a matéria seca degradada e sugerem como ideal a lavagem por 2 minutos para uma quantidade de até 200 sacos, quando o volume de água é de aproximadamente 68 litros.

Outro fator envolvido é o tempo de colonização. McDONALD (1981) observou um lapso de tempo durante o qual não existia qualquer alteração no material incubado. Este tempo, denominado "tempo de colonização" ou "lag time", é aquele necessário para que as bactérias colonizem o substrato para um posterior fracionamento do material.

Alguns autores recomendam para o cálculo da degradação "in situ" de alimentos modelos que levam em consideração o "lag time", incluindo mais um fator de correção na predição da degradabilidade de alimentos, tornando os dados mais precisos (VARGA \& HOOVER, 1983, MERTENS, 1993, MADSEN et al.,1994 ).

Em estudo realizado por MERTENS \& LOFTEN (1980), a exclusão do tempo oh diminuiu o erro residual, fazendo com que os autores utilizassem em seus cálculos de cinética de digestão da fibra o cálculo do "lag time" para que os valores encontrados fossem, segundo eles, mais próximos dos reais.

O uso do "lag time" para cálculo da taxa de degradação do alimento é de extrema importância, já que a utilização de qualquer resultado obtido durante o tempo de colonização afetará a estimativa da velocidade de desaparecimento do alimento (SAMPAIO, 1994). De maneira geral para forrageiras recomenda-se considerar o início da degradação a partir de 6 horas de incubação, para que se elimine o efeito do tempo de colonização e torne mais eficiente a estimativa da degradação. Os valores calculados das frações solúvel, potencialmente degradável e da velocidade de desaparecimento são afetados pelo uso ou não do "lag time" correspondente, podendo o uso deste aumentar a precisão do modelo de estimativa da degradabilidade efetiva do alimento (PETIT et al, 1994). 
Ainda em relação aos procedimentos adotados visando reduzir possíveis variações nos resultados obtidos, algumas medidas podem ser adotadas, como a utilização de alimentos já padronizados junto com os alimentos em estudo, bem como a utilização de sacos "brancos" para permitir correções (NOCEK, 1985; NOCEK, 1988), assim como quantificar o $\mathrm{N}$ proveniente de contaminação bacteriana, o que pode ser feito através da determinaçao da concentração DAPA-ácido diaminopimélico (VALADARES FILHO et al., 1991; CASTILLO ARIAS, 1992).

A contaminação bacteriana pode representar erro de amplitude variável para se estimar a degradabilidade verdadeira da proteína bruta dos alimentos, através da técnica do saco de náilon (VALADARES FILHO et al., 1992). A contaminação é variável em função das fontes alimentares, apresentando-se mais elevada para alimentos volumosos do que para alimentos concentrados (NOCEK,1988).

VALADARES FILHO et al. (1992) estimaram a contaminação bacteriana, utilizando (DAPA) em resíduos da incubação ruminal relativos a silagem de milho, fubá de milho, farelos de algodão, arroz e trigo. Para as degradabilidades aparente e corrigida da matéria seca, a maior diferença encontrada foi em silagem de milho (6,8\%). $O$ autor observou que a contaminação bacteriana em alimentos concentrados foi relativamente pequena e que a decisão de se fazer esta correção depende de mais resultados experimentais. Para alimentos volumosos de baixo teor protéico, entretanto, esta correção deve ser efetuada.

WANDERLEY et al (1993) utilizou o ${ }^{15} \mathrm{~N}$ para estudar a influência da colonização microbiana nas partículas do alimento sobre a determinação da degradabilidade do nitrogênio do grão de milho, casca de milho e feno de alfafa, pelo método da incubação "in situ". $\mathrm{O}$ autor verificou que a maior contaminação ocorreu entre 12 e 24 horas de incubação para todos os alimentos estudados, sugerindo que a colonização microbiana depende do substrato avaliado, e o erro na estimativa do desaparecimento do substrato é maior nos menores e nos maiores tempos de incubação. 


\subsection{Taxa de passagem pelo trato gastrointestinal.}

A taxa de passagem do alimento pelo trato gastrointestinal é usualmente medida fornecendo-se um indicador ao animal junto com o alimento, com a subsequente determinação da concentração do indicador, em amostras coletadas em diferentes segmentos do trato digestivo ou nas fezes (THIAGO \& GLL, 1990)

$\mathbf{O}$ indicador deve possuir algumas determinadas características para que seja considerado ideal, dentre elas: não ser absorvível, não interferir em outras análises, não afetar o trato digestivo nem ser afetado enquanto permanecer neste, ser fisicamente semelhante ou poder se associar ao alimento a ser marcado, e os seus métodos de análise em amostras de conteúdo do trato digestivo ou fezes devem ser sensíveis (FAICHNEY et al.,1975, citado por THIAGO \& GILL, 1990).

Os indicadores podem ser divididos em quatro grandes grupos (THIAGO \& GILL, 1990):

1) aqueles que ocorrem naturalmente nos alimentos como a lignina.

2) aqueles que permanecem em solução através do trato gastrintestinal, tais como o polietilenoglicol (PEG) e complexos de cobalto ou cromo com etilenodiamino tetracético (Co-EDTA ou Cr-EDTA)

3) aqueles que se aderem fisicamente aos alimentos, tais como os corantes; ou quimicamente, a exemplo do cromo, ou elementos raros como o itérbio.

4) indicadores sólidos constituídos de partículas inertes, tais como o plástico.

$\mathrm{O}$ conteúdo do trato gastrointestinal apresenta uma porção sólida e uma líquida, comumente denominadas de "fase sólida" e "fase líquida", que apresentam diferentes taxas de passagem.

UDEN et al. (1980), estudando alguns indicadores de taxa de passagem da fase líquida e da sólida, comumente usados, observaram que nenhum deles foi completamente satisfatório. Os autores também observaram que os indicadores associados à fase sólida são geralmente menos satisfatórios que os associados à fase líquida, devido, principalmente, a problemas relacionados com a passagem do indicador. 
O complexo do íon metálico com fibra vegetal (cromo-mordente) como marcador da fase sólida foi o que mais satisfez os critérios exigidos.

Os complexos de cromo, na maioria materiais orgânicos hidrofilicos, podem ser preparados pela redução do cromo hexavalente com ácido ascórbico. Os produtos trivalentes obtidos com açúcares e amido, por redução de complexos hexavalentes preparados com ácido ascórbico, são solúveis em água e estáveis com álcalis, porém, com proteínas e componentes da parede celular são geralmente insolúveis e indigestíveis. A lavagem do alimento marcado com água no preparo do cromo mordente ligado à parede celular reduz a porção solúvel, aumentando eficiência da determinação da taxa de passagem (UDEN et al. 1980).

A estabilidade e a indigestibilidade da fibra marcada com cromo-mordente são vistos como características desejáveis para o seu uso em estudos de taxa de passagem de sólidos (POORE, 1987)

EHLE (1984) observou aumentos na densidade e na concentração de cromo na parade celular à medida em que foi aumentada a concentração de cromo utilizada para marcar fibra pelo processo do cromo mordente. $\mathbf{O}$ aumento na densidade das partículas marcadas pode subestimar a taxa de passagem de partículas não marcadas.

A fibra marcada com cromo torna-se totalmente indigestível e, portanto, sua passagem pelo trato digestivo decorre em consequência da redução mecânica do tamanho das partículas (PIAGGIO et al., 1991).

O alimento marcado pode ser introduzido diretamente no rúmen (UDEN et al., 1980) ou misturado ao concentrado (COLUCCI et al., 1982). Quando colocado no rúmen, pode influênciar a estimativa da taxa de passagem, uma vez que pode não ser misturado de maneira uniforme com o conteúdo ruminal comprometendo a redução do tamanho de partícula, umedecimento e masceração do alimento, associadas com a mastigação (POORE, 1987) 
As amostras para a determinação da concentração de cromo e posterior estimativa da taxa de passagem podem ser obtidas no rúmen, duodeno e/ou fezes (POORE, 1987).

GOETSCH \& OWENS (1985) demonstraram a importância do local da amostragem na determinação da taxa de passagem, pois houve diferenças quando esta foi estimada a partir de amostras do rúmen, duodeno, íleo e fezes.

A amostragem de fezes parece ser o meio mais prático para determinação da taxa de passagem, sendo recomendados intervalos de coleta de 6 horas durante 6 a 7 dias consecutivos (POORE, 1987)

Métodos para a estimativa das curvas de excreção e taxa de passagem em ruminantes foram analisados por GROVUM \& WILLIAMS (1973), ELLIS et al. (1979), citados por POORE (1987) e BLAXTER et al. (1956), citado por THIAGO \& GILL (1990).

GROVUM \& WILLIAMS (1973) e ELLIS et al. (1979) estudaram modelos que interpretam a taxa de passagem em dois compartimentos, sendo um com taxa de passagem rápida e outro com taxa lenta.

De acordo com GROVUM \& WILLIAMS (1973), o compartimento com passagem lenta representa o rúmen e o de passagem rápida o intestino.

ELLIS et al. (1979), porém, são favoráveis ao conceito de que há dois compartimentos de ruminação no rúmen, um contendo partículas grandes e outro de partículas pequenas, ambos apresentando suas respectivas taxas de passagem. As taxas lenta e rápida estão associadas a processos ocorrendo no rúmen, e não no rúmen e nos intestinos. Este modelo não é muito utilizado pela dificuldade de ajuste das curvas de excreção por indicadores e por estimar valores elevados de passagem para a taxa lenta.

BLAXTER et al. (1956), citados por THIAGO \& GILL (1990), propuseram um modelo para estudar o fluxo do alimento em três compartimentos (rúmen, abomaso e intestinos). 
Ultimamente assume-se que a taxa lenta descreve a passagem pelo rúmen, enquanto que a rápida é uma combinação das ocorrências no rúmen, abomaso e intestinos (GOETSCH \& OWENS, 1985).

\subsubsection{Fatores que influenciam.}

Segundo MERTENS (1993) a taxa de passagem é afetada por fatores intrínsecos e extrínsecos.

Características intrínsicas da parede celular podem influir sobre a velocidade de passagem do alimento oferecendo maior ou menor resistência a redução do tamanho da partícula. A composição química, a anatomia e físiologia da planta são determinantes desta resistência (MERTENS, 1993). As características intrínsecas podem estar afetando não somente a redução do tamanho de partícula, mas também, a vazão de partículas pequenas do rúmen.

A saída de partículas do rúmen é afetada pela densidade e tamanho da partícula. WELCH (1986) considerou que a densidade e o tamanho da partícula são os fatores mais importantes relacionados com a passagem do alimento pelo rúmen.

WELCH (1986) observou que partículas com densidade menor que 1,0 passam lentamente e são submetidas a ruminação mais intensa; partículas com densidade de 1,17 a 1,42 passam mais rapidamente, e com densidade entre 1,17 a 2,14 não são mastigadas e passariam pelo rúmen muito lentamente, porém sua hidratação no rúmen causa aumento na densidade dependendo da capacidade específica da fibra do alimento em absorver água.

A literatura mostra que em geral as forragens passam mais lentamente que os concentrados em dietas completas; porém nem sempre estas diferenças podem ser observadas para toda relação concentrado:forragem e todos níveis de ingestão (POORE, 1987). 
A retenção de pequenas partículas no rúmen é necessária para manter a população microbiana. Para WELCH (1986), o mecanismo exato pelo qual o tamanho de partícula afeta a taxa de passagem não é claro, podendo ser, dentre outros, um mecanismo de seleção do oríficio retículo omasal. $O$ tamanho de partícula poderia atuar como um determinante da densidade e esta, por sua vez, seria o controlador da taxa de passagem do alimento.

EHLE (1984) também considerou a densidade como um dos principais fatores relacionados com a taxa de passagem, apesar de levar em conta ainda a digestibilidade, ruminação, mastigação e características químicas inerentes à planta. Com o aumento da densidade das partículas, houve aumento da taxa de passagem pelo rúmen.

Segundo MERTENS (1993), aos fatores extrínsicos estariam relacionadas a característica do animal, da dieta e do processamento do alimento, uma vez que afeta 0 tamanho de partícula e a densidade do alimento. Redução do tamanho da partícula aumenta a densidade, resultando em aumento da ingestão de alimento e do desempenho no animal, principalmente para dietas com forragens de baixa qualidade e alto teor de fibra.

Segundo EVANS (1981), a solubilização pela ação dos microrganismos do rúmen, os gases produzidos durante o processo digestivo, além da presença de material indigestível no rúmen, são fatores que influênciam a taxa de passagem pelo rúmen. Outros fatores, como nível de ingestão de alimento, forma física e composição da dieta também afetam a taxa de passagem. Em geral dietas com alto nível de concentrado apresentam taxa de passagem inferior a dietas com altos níveis de forragem. Houve correlação positiva entre o nível de forragem da dieta e a taxa de passagem de sólidos pelo rúmen e correlação negativa entre a concentração de energia e a taxa de passagem de sólidos. $\mathrm{O}$ efeito do aumento do nível de forragem da dieta resulta em aumento na taxa de passagem, provavelmente devido a maior ruminação e salivação. 
O efeito do nível de concentrado da dieta sobre a taxa de passagem foi estudado por COLUCCI (1982), fornecendo dietas com 32 e $83 \%$ de forragem, com dois níveis de ingestão (à vontade e manutenção), para vacas secas e em lactação. Foi observado que para ingestão a nível de manutenção a taxa de passagem de forragem (silagem de milho) e de concentrado (milho e farelo de soja) aumentou significativamente com a elevação do nível de forragem da dieta. $\mathrm{O}$ mesmo efeito não foi observado para as dietas fornecidas à vontade, indicando que pode não ocorrer efeito do nível de forragem sobre a taxa de passagem de sólidos quando os níveis de ingestão são altos (à vontade).

OWENS \& GOETSCH (1986), citado por POORE (1987), analisando dados de diversos trabalhos que estudaram o efeito de níveis de concentrado e de forragem sobre a taxa de passagem, propuseram a classificação apresentada na tabela 1.

Tabela 1. Taxas de passagem de concentrados e forragens em dietas com diferentes níveis de concentrado

\begin{tabular}{ccccccccc}
\hline & \multicolumn{3}{c}{ Concentrado } & & \multicolumn{3}{c}{ Forragem } \\
\cline { 2 - 4 } \cline { 6 - 8 } \% Concentrado & $\mathrm{N}$ & $\mathrm{Kp}$ & $\wp$ & & $\mathrm{N}$ & $\mathrm{Kp}$ & $\wp$ \\
\hline$<20 \%$ & 5 & 5,0 & 0,5 & & 70 & 3,1 & 0,2 \\
$20-50 \%$ & 29 & 6,9 & 0,2 & & 53 & 3,7 & 0,3 \\
$50-80 \%$ & 17 & 3,4 & 0,3 & & 6 & 3,5 & 0,3 \\
$>80 \%$ & 19 & 3,1 & 0,2 & & 1 & 2,9 & - \\
\hline
\end{tabular}

Fonte: OWENS \& GOETSCH (1986), adaptada por POORE (1987)

$\mathrm{N}$ : número de observações

$\mathrm{Kp}$ : taxa de passagem pelo rúmen $(\% / \mathrm{h})$

§o: desvio padrão

Nota-se que a taxa de passagem da forragem é menos influenciada pelo nível de concentrado da dieta que a taxa de passagem do concentrado, conforme os dados apresentados pelo autor. 
POORE (1987), avaliando o efeito de dietas com 30, 60 e $90 \%$ de concentrado sobre a taxa de passagem dos sólidos dos volumosos (feno de alfafa e palha de trigo) e do concentrado (sorgo floculado), também observou um decréscimo na taxa de passagem com o aumento do nível de concentrado da dieta.

A taxa de passagem da dieta pode diminuir com o aumento do nível de concentrado das dietas, porém, este fato não é observado em todos os trabalhos realizados. Altos níveis de ingestão podem eliminar o efeito do nível de concentrado da dieta sobre a taxa de passagem (POORE, 1987).

Diferentes taxas de passagem são assumidas pelo CNCPS para diferentes níveis de ingestão (SNIFFEN et al., 1992) . A tabela 2 traz valores de taxa de passagem de alguns alimentos conforme o nível de ingestão.

Os valores assumidos no CNCPS são derivados dos trabalhos realizados por COLUCCI et al. (1982), ERDMAN et al. (1987) e HARTNELL \& SATTER (1979).

Tabela 2. Taxas de passagem (\%/ hora) assumidas pelo CNCPS para alguns alimentos.

\begin{tabular}{llll}
\hline \multicolumn{1}{c}{ Alimento } & \multicolumn{3}{c}{ Nível de Mantença } \\
\cline { 2 - 4 } & $1 \mathrm{X}$ & $2 \mathrm{X}$ & $3 \mathrm{X}$ \\
\hline Silagem de Milho (> 50\% de grãos) & 2,0 & 2,5 & 3,0 \\
Silagem de Milho (30-50\% de grãos) & 1,5 & 2,0 & 2,5 \\
Silagem de Milho (< 30\% de grãos) & 1,0 & 1,5 & 2,0 \\
Farelo de soja & 3,5 & 4,0 & 5,0 \\
Farelo de algodão & 3,5 & 4,0 & 5,0 \\
Milho Grão & 3,5 & 4,0 & 5,0 \\
\hline
\end{tabular}

Fonte: SNIFFEN et al. (1992) 


\section{3. "Sistema de carboidrato e proteína líquidos para avaliação de dietas de bovinos" (CNCPS).}

Em 1990 foi editada a primeira versão do CNCPS, onde FOX et al. procuraram estabelecer relações não somente de exigência animal, composição de alimentos, comportamento do alimento no trato gastrointestinal, mas também fatores relacionados ao grau de estrutura corporal e tipo de animal, condições de ambiente e manejo aos quais estes animais são submetidos. Trata-se de um sistema que prevê o desempenho animal para inúmeras combinações de alimento-animal-manejo-condições ambientes.

A maioria dos dados que geraram o CNCPS são provenientes de estudos realizados pelo NRC (1985, 1989) e ARC (1984), porém, muito foi modificado e adaptado de acordo com uma série de dados levantados pelos autores.

\subsubsection{Frações dos alimentos.}

O CNCPS proposto por FOX et al. (1990) assume que os alimentos são compostos de proteína, carboidratos, gordura, cinzas e água, sendo a proteína e os carboidratos subdivididos de acordo com sua degradação ruminal e características de digestibilidade. Para fins de análise, as frações citadas devem ser determinadas a partir das seguintes análises:

1. matéria seca determinada por secagem a $60^{\circ} \mathrm{C}$.

2. fibra em detergente neutro, nitrogênio insolúvel em detergente neutro e nitrogênio insolúvel em detergente ácido, segundo metodologia de análise proposta por GOERING \& VAN SOEST, 1970.

3. nitrogênio total, determinado através de macro ou micro Kjeldahl.

4. cinzas por incineração a $530^{\circ} \mathrm{C}$.

5. gordura, através do procedimento descrito pela A.O.A.C.

A solubilidade e degradabilidade da proteína são determinadas de acordo com os métodos de KRISHNAMOORTY et al. (1983), citados por FOX et al. (1990). 


\subsubsection{Proteína}

Significativo progresso para a compreensão dos mecanismos de utilização do nitrogênio por ruminantes se deve a evolução dos métodos de avaliação do nitrogênio da dieta em termos de requerimentos para o animal. A solubilidade do nitrogênio da dieta é um fator que influencia a degradação da proteína no rúmen (WOHLT et al, 1973).

A solubilidade da proteína em meio contendo tampões minerais e a extensão de digestão no rúmen estão altamente correlacionadas (HENDRICK \& MARTIN, 1963, citados por KRISHNAMOORTY et al., 1982)

KRISHNAMOORHY et al. (1982) afirmam que a solubilidade do nitrogênio pode ser obtida através de dois meios. Um deles seria através de solventes, como o proposto por WOHLT et al. (1973), e o outro através de detergentes, para a análise do nitrogênio da fibra (GOERING \& VAN SOEST, 1970).

Em estudo avaliando as duas vias de fracionamento do nitrogênio alimentar KRISHNAMOORHY et al. (1982) propuseram o esquema mostrado na figura 1.

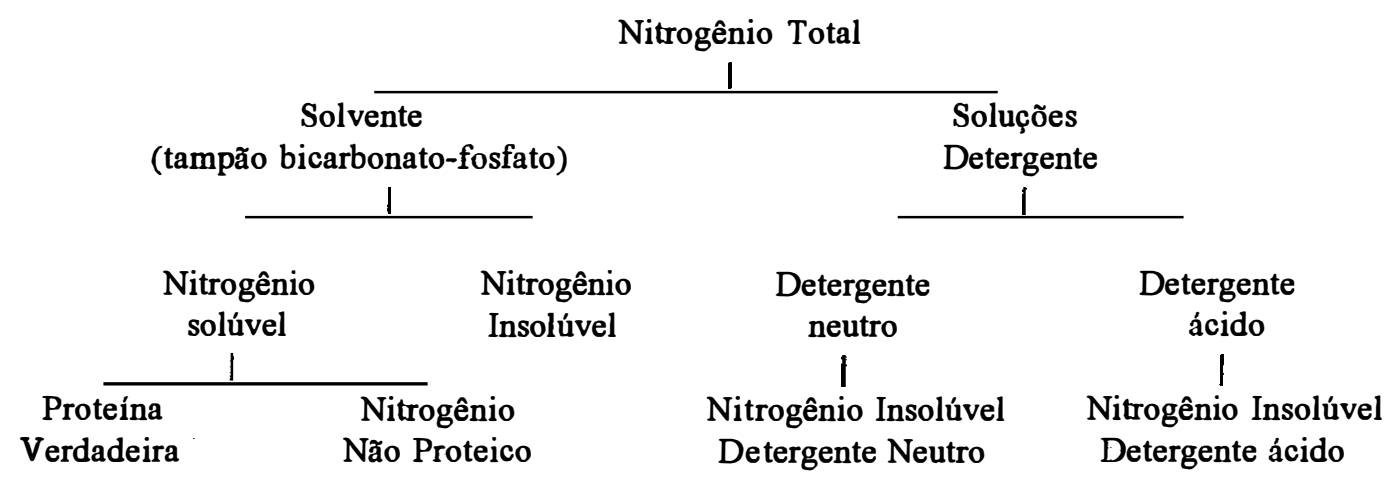

Figura 1. Esquema representativo do fracionamento do nitrogênio dos alimentos. Fonte: KRISHNAMOORTY et al. (1982) 
Os autores definiram o nitrogênio insolúvel em detergente neutro como sendo aquele que está ligado à parede celular. $\mathbf{O}$ nitrogênio insolúvel em detergente ácido é o nitrogênio lignificado e os produtos de Maillard, sendo estes não aproveitados pelo organismo animal. Foi demostrado que o conteúdo de nitrogênio solúvel é muito variável, sendo as variações atribuídas a características inerentes ao alimento, às partes do grão (grão de milho ou glútem) ou ao processamento ao qual foi submetido. Em forragens a proteína verdadeira é baixa em relação ao nitrogênio total, enquanto em concentrados é mais elevada.

O NRC (1985) divide a proteína do alimento em três frações. A primeira constituída de compostos nitrogenados não protéicos, ou proteína degradada muito rapidamente; a segunda, aquela considerada potencialmente degradável no rúmen, e apresenta taxa de desaparecimento de 2 a $7 \%$ por hora; a última, denominada de "indisponível", pois, não é aproveitada pelo organismo animal, não sendo digestível a nível de rúmen ou de intestinos.

O ARC (1984) considera a proteína de maneira idêntica ao NRC, porém o AFRC (1992) apresenta quatro divisões da fração protéica (VALADARES FILHO, 1994): 1) rapidamente degradada no rúmen, 2) lentamente degradada no rúmen, 3) não degradada no rúmen, 4) não degradada no rúmen e indigestível, correspondendo ao nitrogênio insolúvel em detergente ácido.

Já o CNCPS, além da divisão proposta pelo NRC, subdivide a fração protéica de acordo com diferentes taxas de degradação e passagem pelo rúmen e pelas diferentes porções do trato gastrintestinal. A proteína é dividida em: solúvel, correspondente à maior parte do nitrogênio não protéico (A), verdadeira ou compostos nitrogenados protéicos (B) e nitrogênio indisponível, representado pelo nitrogênio insolúvel em detergente ácido e indigestível nos intestinos (C), segundo SNIFFEN et al. (1992).

A fração $A$ apresenta taxa de degradação muito alta, $C$ taxa de degradação igual a zero, e B é subdividida em três frações (B1, B2 e B3) baseadas nas respectivas taxas de degradação ruminal. WEISS et al. (1992) porém, consideram que o nitrogênio insolúvel em detergente ácido apresenta digestibilidade igual a 30\% para forragens e $60 \%$ para concentrados. 
SNIFFEN et al. (1992), baseados nos trabalhos de KRISHNAMOORTHY et al. (1982), VAN SOEST (1981) e VAN SOEST et al (1982), consideraram a fração B1 como sendo a proteína solúvel subtraído o nitrogênio não protéico (peptídeos e aminoácidos) rapidamente degradado no rúmen. B1 apresenta taxa de degradação muito superior à taxa de passagem. Em forragens ela corresponde a aproximadamente $5 \%$ do total da proteína solúvel. Em silagens, a maior parte do nitrogênio solúvel é não protéico.

A fração B2 corresponde à proteína bruta subtraída a proteína solúvel + fração B3 + fração C. B2 apresenta disponibilidade média com valor de taxa de degradação muito próximo ao da taxa de passagem. Um exemplo é a gluteina presente em grãos pequenos (FOX \& BARRY, 1994).

A última fração (B3) corresponde à proteína insolúvel em detergente neutro subtraíndo-se a proteína insolúvel em detergente ácido. É de disponibilidade lenta, pois está associada à parede celular, e grande parte não é degradada no rúmen. Suplementos protéicos apresentam baixa proporção de B3, mas forragens, grãos fermentados e subprodutos apresentam elevada proporção de B3 (KRISHNAMOORTY et al., 1982). Para o CNCPS, grande parte de B3 escapa da degradação ruminal, uma vez que a taxa de passagem é superior à taxa de degradação.

Dados de proteína bruta, proteína solúvel, nitrogênio não protéico, nitrogênio insolúvel em detergente neutro e detergente ácido utilizados para obtenção de B1, B2 e B3 e as taxas de digestão assumidas para estas frações de alguns alimentos pelo CNCPS são apresentadas na tabela 3.

VALADARES FILHO (1994) apresentou valores de nitrogênio insolúvel em detergente ácido, em relação à proteína bruta, de silagem de milho igual a $15 \%$ e do farelo de soja igual a $4,2 \%$. 
Tabela 3. Valores das frações protéicas assumidos pelo CNCPS para alguns alimentos.

\begin{tabular}{lccccccccc}
\hline & & & & & & \multicolumn{3}{c}{ Taxa de Digestão } \\
\cline { 8 - 10 } \multicolumn{1}{c}{ Alimento } & PB & Psol & NNP & NIDN & NIDA & B1 & B2 & B3 \\
& $(\%)$ & $(\%$ PB) & $(\%$ Psol) & $(\% \mathrm{~PB})$ & $(\% \mathrm{~PB})$ & $(\% / \mathrm{h})$ & $(\% / \mathrm{h})$ & $(\% / \mathrm{h})$ \\
\hline Silagem (25\% grãos) & 8,3 & 55 & 100 & 16 & 9 & 300 & 10 & 0,20 \\
Silagem (35\% grãos) & 8,6 & 50 & 100 & 16 & 9 & 300 & 10 & 0,20 \\
Silagem (45\% grãos) & 9,0 & 45 & 100 & 16 & 8 & 300 & 10 & 0,20 \\
Sorgo grão & 12,4 & 12 & 33 & 10 & 5 & 135 & 6 & 0,12 \\
F. de soja (44\% PB) & 49,0 & 20 & 55 & 5 & 2 & 230 & 11 & 0,20 \\
F. de soja (49\% PB) & 55,0 & 20 & 55 & 5 & 2 & 230 & 11 & 0,20 \\
\hline
\end{tabular}

Fonte: CNCPS (1994).

PB: proteína bruta

NNP: nitrogênio não protéico

NIDA: nitrogênio insolúvel em detergente ácido
Psol: proteína solúvel

NIN: nitrogênio insolúvel em detergente neutro F. de soja: farelo de soja

\subsubsection{Carboidratos}

Com o surgimento do sistema de detergentes (GOERING \& VAN SOEST, 1970), foi possível o fracionamento da fibra dos alimentos. Juntamente com a evolução das metodologias de determinação de amido e açúcares, foi possível melhor caracterização dos carboidratos que constituem os alimentos utilizados nas dietas.

CHANDLER (1978), citado por PATTON (1994), apresentou um esquema que ilustra as relações entre os tipos de carboidratos de alimentos utilizados em dietas de ruminantes (figura 2). A divisão apresentada pelo autor representa a distribuição das diversas frações dos alimentos, a partir do surgimento do sistema de detergentes, e seus respectivos componentes. 


\begin{tabular}{|c|c|c|c|c|}
\hline \multirow{5}{*}{$\begin{array}{l}\text { Conteúdo } \\
\text { Celular }\end{array}$} & Cinzas & & & \multirow[t]{7}{*}{ - } \\
\hline & Extrato Etéreo & & & \\
\hline & Proteina & & & \\
\hline & Açúcares & \multirow{6}{*}{$\begin{array}{c}\text { Total } \\
\text { de } \\
\text { Carboidratos }\end{array}$} & Carboidratos & \\
\hline & Amido & & & \\
\hline \multirow{5}{*}{$\begin{array}{l}\text { Parede } \\
\text { Celular }\end{array}$} & Pectina & & \multirow{4}{*}{$\begin{array}{l}\text { Carboidratos } \\
\text { Estruturais }\end{array}$} & \\
\hline & Hemicelulose & & & \\
\hline & Lignina & & & \multirow{2}{*}{$\begin{array}{l}\text { Fibra em } \\
\text { Deter. Ácido }\end{array}$} \\
\hline & Celulose & & & \\
\hline & Cinzas & & & \\
\hline
\end{tabular}

Figura 2. Constituintes nutritivos dos alimentos e relações entre os tipos de carboidratos em alimentos de dietas de ruminantes.

Fonte: CHANDLER (1978) adaptado por PATTON (1994)

O CNCPS também considera que os carboidratos são divididos em não estruturais (açúcares, amido e pectina) e estruturais (celulose, hemicelulose e lignina). Para a determinação dos estruturais é utilizado o sistema de detergentes uma vez que o método de fibra bruta não determina a lignina e a celulose.

Todos os carboidratos não estruturais são fermentados pelas bactérias do rúmen capazes de utilizar nitrogênio de amônia ou peptídeos para a produção de proteína microbiana (RUSSEL et al. 1992).

Segundo SNIFFEN et al. (1992), o CNCPS ainda classifica os carboidratos de acordo com suas diferentes taxas de degradação, dividindo-os em quatro frações: A, B1, B2 e C. A fração A e B1 correspondem aos carboidratos não estruturais, B2 à porção disponível da parede celular, e C a porção indisponível da parede celular.

A fração A (açúcares e ácidos orgânicos) é rapidamente degradada no rúmen, apresentando taxa de degradação muito superior à taxa de passagem. Os açúcares normalmente representam pequena parcela nos alimentos normalmente utilizados em dietas de bovinos, exceto no caso de forragens frescas (SNIFFEN et al., 1992). 
A fração B1 representa os carboidratos não estruturais amido e pectina, sendo lentamente degradada no rúmen, apresentando taxa de degradação pouco superior à taxa de passagem. $\mathbf{O}$ amido normalmente é rapidamente digerido no rúmen, mas contém uma porção insolúvel, de degradação mais lenta (SNIFFEN et al., 1992).

A pectina, apesar de ser participante da parede celular, é solúvel e rapidamente degradada no rúmen (PATTON, 1994). Por se apresentar em níveis muito baixos, ela tem pouca importância em gramíneas e cereais, mas deve ser considerada quando se utilizam leguminosas e subprodutos como a polpa de citrus (VAN SOEST, 1982, citado por SNIFFEN et al. 1992).

No CNCPS, B2 corresponde à fibra em detergente neutro disponível para a degradação ruminal. É obtida subtraindo-se da fração fibra em detergente neutro a fração C. A fração B2 apresenta taxa de degradação baixa no rúmen, com valores muito próximos aos da taxa de passagem.

A fração $C$ corresponde à lignina $\times 2,4$, sendo o material remanecente após 72 horas de digestão "in vitro". Apresenta taxa de degradação igual a zero, e é considerada a porção indisponível da parede celular. $O$ fator 2,4 é proveniente dos trabalhos realizados por SMITH et al. (1972) e MERTENS (1973), citados por SNIFFEN et al. (1992), A lignina pode representar de 5 a $25 \%$ da parede celular, sendo os valores mais elevados encontrados em leguminosas (VAN SOEST, 1982, citado por SNIFFEN et al. 1992).

Dados do amido em relação aos carboidratos não estruturais, fibra em detergente neutro e lignina utilizados para obtenção de A, B1 e B2 e as taxas de digestão assumidas para estas frações em alguns alimentos, pelo CNCPS, são apresentadas na tabela 4 .

PATTON (1994) apresentou em sua revisão sobre metabolismo de carboidratos em ruminantes porcentagem de amido em vários alimentos: para a silagem de milho, farelo de soja (48\% de proteína) e sorgo grão foram $39,4 \pm 9,5 ; 12,9$ e $73,4 \pm 8,7$, respectivamente. 
Tabela 4. Valores das frações de carboidratos assumidos pelo CNCPS para alguns alimentos.

\begin{tabular}{lccccccc}
\hline & & & & \multicolumn{2}{c}{ Taxa de Digestão } \\
\cline { 6 - 8 } \multicolumn{1}{c}{ Alimento } & AM & FDN & LIG & A & B1 & B2 \\
& $(\%$ CNS) & $(\%)$ & $(\% F D N)$ & $(\% / h)$ & $(\% / h)$ & $(\% / h)$ \\
\hline Silagem (25\% grãos) & 100 & 52 & 9,62 & 275 & 25 & 4 \\
Silagem (35\% grãos) & 100 & 46 & 8,70 & 275 & 30 & 4 \\
Silagem (45\% grãos) & 100 & 41 & 7,32 & 275 & 30 & 4 \\
Sorgo grão & 90 & 23 & 6,09 & 150 & 12 & 5 \\
F. de soja (44\% PB) & 90 & 14 & 2,14 & 300 & 25 & 6 \\
F. de soja (49\% PB) & 90 & 8 & 2,50 & 300 & 25 & 6 \\
\hline
\end{tabular}

Fonte: CNCPS (1994).

AM: amido

FDN: fibra em detergente neutro

PB: proteína bruta
CNS carboidratos não estruturais

LIG: lignina

F. de soja: farelo de soja

\subsection{Degradação 'in situ" de silagem de milho, farelo de soja e sorgo grão.}

JANICKI \& STALLINGS (1988) avaliaram a degradabilidade "in situ"da proteína bruta da silagem de milho. A silagem avaliada apresentava $41,4 \%$ de matéria seca, $46,9 \%$ de fibra em detergente neutro, $24,2 \%$ de fibra em detergente ácido e $7,9 \%$ de proteína bruta. Foram obtidos os valores de $71,6 \%$ para a fração protéica solúvel, $20,1 \%$ para a fração protéica potencialmente degradável e $8,3 \%$ para a fração protéica indegradável. A taxa de degradação da proteína bruta foi $5 \% / \mathrm{h}$.

VON $\cdot$ KEYSERLINGK \& MATHISON (1989) avaliaram a degradabilidade ruminal da matéria seca, nitrogênio e fibra em detergente neutro de silagem de milho (tabela 5), apresentando 28 e $37 \%$ de matéria seca. A silagem com $28 \%$ de matéria seca apresentava $10,7 \%$ de proteína bruta, $59,4 \%$ de fibra em detergente neutro, $40,6 \%$ de fibra em detergente ácido e $0,25 \%$ de nitrogênio insolúvel em detergente ácido. 
A silagem com $37 \%$ de matéria seca apresentava $13,4 \%$ de proteína bruta, $54,6 \%$ de fibra em detergente neutro, $38,5 \%$ de fibra em detergente ácido e $0,21 \%$ de nitrogênio insolúvel em detergente ácido. Os dados obtidos são apresentados na tabela 5.

Tabela 5. Porcentagem de matéria seca , fibra em detergente neutro e proteína bruta solúvel, potencialmente degradável, indegradável e a taxa de degradação da fração potencialmente degradável de silagem de milho com dois níveis de matéria seca.

\begin{tabular}{|c|c|c|c|c|c|c|c|c|}
\hline \multirow{2}{*}{ Fração } & \multicolumn{4}{|c|}{ Silagem com $28 \%$ MS* } & \multicolumn{4}{|c|}{ Silagem com $37 \% \mathrm{MS}^{* *}$} \\
\hline & A & B & $\mathbf{C}$ & c & A & B & C & c \\
\hline MS & 29,6 & 43,9 & 26,6 & 3,0 & 33,0 & 45,1 & 22,0 & 3,2 \\
\hline PB & 56,3 & 23,0 & 20,7 & 5,7 & 64,2 & 23,0 & 12,9 & 1,0 \\
\hline FDN & - & 62,3 & 37,8 & 3,6 & - & 71,8 & 28,3 & 2,8 \\
\hline
\end{tabular}

Fonte: Adaptado VON KEYSERLINGK \& MATHISON (1989).

A: fração solúvel (\%); B: fração potencialmente degradável (\%); C: fração indegradável (\%); c:taxa de degradação de $\mathrm{B}(\% / \mathrm{h})$; FDN: fibra em detergente neutro; PB: proteína bruta; MS: matéria seca

* taxa de passagem de sólidos: $2,5 \% / \mathrm{h}$

** taxa de passagem de sólidos: $3,7 \% / \mathrm{h}$

SUSMEL et al. (1990) também avaliaram a degradabilidade ruminal da matéria seca, nitrogênio e componentes da fração fibra da silagem de milho ( $7,8 \%$ de proteína bruta, $54,1 \%$ de fibra em detergente neutro e $0,4 \%$ de nitrogênio insolúvel em detergente ácido). Os coefícientes obtidos de degradabilidade, "lag time" e degradabilidade efetiva da matéria seca, nitrogênio e componentes da fração fibra constam na tabela 6 .

ERASMUS et al. (1990b) avaliaram a degradabilidade "in situ" da silagem de milho com $8,2 \%$ de proteína bruta, $47,4 \%$ de fibra em detergente neutro e $30,1 \%$ de fibra em detergente ácido, em vacas holandesas recebendo dieta com $45 \%$ de volumoso e $55 \%$ de concentrado. A dieta apresentava $15,2 \%$ de proteína bruta e $18,2 \%$ de fibra bruta. A proteína bruta apresentou $\mathbf{7 4 , 8} \%$ de fração solúvel, $10,8 \%$ de fração potencialmente degradável e taxa de degradação de $6 \% / \mathrm{h}$. A degradabilidade efetiva foi $83,0 \% ; 80,8 \%$ e $79,5 \%$ utilizando-se respectivamente taxas de passagem de 2,5 e $8 \% / h$. 
Tabela 6. Coeficientes de degradabilidade, "lag time" e degradabilidade efetiva, da matéria seca, nitrogênio e componentes da fração fibra da silagem de milho.

\begin{tabular}{llllll}
\hline \multicolumn{1}{c}{ Fração } & A & B & c & l & Dg* \\
\hline Matéria seca & 26 & 56 & 2,7 & - & 54 \\
Nitrogênio & 47 & 31 & 5,6 & - & 69 \\
FDN & 24 & 65 & 2,4 & 5,9 & 51 \\
Hemicelulose & 23 & 71 & 2,3 & 5,7 & 86 \\
Celulose & 6 & 87 & 2,0 & 0,7 & 92 \\
Lignina & 3 & 69 & 0,2 & 10,9 & 70 \\
\hline
\end{tabular}

Fonte: Adaptado SUSMEL et al. (1990).

A: fração solúvel (\%)

c: taxa de degaradação de $\mathrm{B}(\% / \mathrm{h})$

Dg: degradação efetiva (\%)
B: fração potencialmente degradável (\%)

1: "lag time" (h)

FDN: fibra em detergente neutro

* taxa de passagem assumida: $2,5 \% / \mathrm{h}$

VALADARES FILHO et al. (1992) avaliaram a degradabilidade da proteína bruta e matéria seca da silagem de milho com $6,4 \%$ proteína bruta e $34,1 \%$ de fibra em detergente ácido, corrigidas pela contaminação microbiana. Foram utilizadas vacas mestiças, gestantes, alimentadas com dieta contendo $55 \%$ de silagem de milho e $45 \%$ de fubá de milho, farelo de soja e uréia. $\mathrm{O}$ valor obtido de degradabilidade da matéria seca corrigida pela contaminação microbiana foi $44,2 \%$ e aparente da ordem de $41,4 \%$. A degradabilidade da proteína aparente foi $52 \%$ e corrigida $71,6 \%$.

MADSEN et al. (1994) determinaram a degradabilidade da fibra em detergente neutro da silagem de milho (contendo $44,6 \%$ de fibra em detergente neutro), obtendo $1,1 \%$ de fração solúvel, $64,6 \%$ de fração potencialmente degradável e $0,32 \%$ de fração indegradável. O "lag time" foi de 13,95 horas.

HA \& KENNELLY (1984) determinaram a degradabilidade efetiva da matéria seca e do nitrogênio do farelo de soja em dieta com $60 \%$ de concentrado e $40 \%$ de volumoso. A fração solúvel verificada para a matéria seca foi de $21,1 \%$ e para o nitrogênio foi de $10,3 \%$. A taxa de degradação da matéria seca foi de $5 \% / \mathrm{h}$ e do nitrogênio $3,6 \% / \mathrm{h}$ 
Taxas de desaparecimento da matéria seca de $9,8 \% / \mathrm{h}$ e do nitrogênio de $9,7 \% / \mathrm{h}$ para o farelo de soja, moído a $2 \mathrm{~mm}$, e colocado na proporção de $25,3 \mathrm{mg} / \mathrm{cm}^{2}$, foram obtidas por NOCEK (1985), utilizando vacas holandesas em início de lactação, recebendo dieta contendo volumoso e concentrado na proporção de $50 \%$.

ERASMUS \& PRINSLOO (1988) utilizaram quatro vacas holandesas em lactação para avaliar a degradabilidade "in situ" da proteína bruta (PB) de alimentos definidos pelo autor como: torta de soja (44,\% PB), farelo de soja tostado (40\% PB) e farelo de soja não aquecido (34,9\% PB). A dieta continha $15,2 \%$ de proteína bruta e $18,2 \%$ de fibra bruta, sendo $45 \%$ de volumoso e $55 \%$ de concentrado. Os valores obtidos para a fração protéica solúvel foram de $10 \%$ para a torta, de $21 \%$ para o farelo tostado e de $28 \%$ para o farelo não aquecido, respectivamente. As taxas de desaparecimento da proteína bruta foram $6,79 \% / \mathrm{h}$ para a torta, $3,18 \% / \mathrm{h}$ para o farelo tostado e de $9,09 \% / \mathrm{h}$ para o farelo não aquecido. Calculando a degradabilidade efetiva da proteína bruta do farelo de soja não aquecido sob diferentes taxas de passagem, foram obtidos valores de $79,5 \% ; 61,9 \%$ e $51,4 \%$, para taxas de degradação de 2,5 e $8 \% / h$, respectivamente.

A degradabilidade efetiva da proteína bruta do farelo de soja sob dois níveis de concentrado foi avaliada por RODRIGUEZ et al . (1991). As dietas testadas foram: A: $50 \%$ concentrado comercial e $50 \%$ feno de capim gordura e B:25\% do mesmo concentrado comercial e $75 \%$ de capim gordura. A degradabilidade efetiva da proteína bruta do farelo de soja em animais ingerindo as dietas A e B, considerando-se as taxas de passagem de 2 , 5 e $8 \% / h$, foram: $89,7 \%$; $89,5 \%$ e $77,3 \%$ e $76,6 \% ; 68,9 \%$ e $68,1 \%$, respectivamente. Não houve diferença $(P>0,05)$ quanto a taxa de degradação $(10,38$ vs $9,79 \% / h$ ) do farelo de soja em relação às duas dietas.

SILVA E WANDERLEY (1992a) estudaram a degradabilidade ruminal da matéria seca e proteína bruta do grão de soja inteiro ou quebrado, em vacas mestiças recebendo $38 \%$ de silagem de milho, $51 \%$ de capim napier picado e $11 \%$ de concentrado comercial. Os valores obtidos para a fração solúvel, potencialmente degradável e taxa de degradação da matéria seca foram de $6,88 \%, 78,28 \%$, e $2,5 \% / \mathrm{h}$ para o grão de soja inteiro, e $18,5 \%, 96,7 \%$ e $3,2 \% / h$ para o grão de soja quebrado, respectivamente. 
Para a proteína bruta os valores da fração potencialmente degradável e a taxa de degradação foram de $76,6 \%$ e $2,9 \%$ /h para o grão inteiro e de $98,6 \%$ e $8,6 \%$ /h para o grão quebrado. As diferenças encontradas entre todos os parâmetros avaliados tanto para a proteína como para a matéria seca do grão inteiro ou quebrado diferiram significativamente entre si $(\mathrm{P}<0,01)$.

Em outro trabalho, com os mesmos animais e dieta, SLVA E WANDERLEY (1992b) avaliaram a degradabilidade do farelo de soja e obtiveram 32,03\%; 97,33\% e $2,06 \% / h$ para a fração solúvel, potencialmente degradável e taxa de degradação da matéria seca, respectivamente. A fração potencialmente degradável e a taxa de degradação da proteína bruta foram $97,33 \%$ e $6,62 \% / \mathrm{h}$, respectivamente.

CASTILLO ARIAS et al. (1993) avaliaram a degradabilidade ruminal da matéria seca e proteína bruta do farelo de soja com 50,7\% de proteína bruta. Foram utilizados animais $7 / 8$ holandes-zebu recebendo dieta com $80 \%$ de capim colonião e $20 \%$ de concentrado à base de fubá de milho, farelo de algodão e de soja. A taxa de passagem da dieta foi $5 \% / h$. Para a matéria seca, a fração solúvel foi de $23,25 \%$, a potencialmente degradável de $76,03 \%$ e a taxa de degradação 7,2 \%/h. Para a proteína bruta, os valores foram $11,28 \%, 89,78 \%$ e $6,7 \% / h$ para a fração solúvel, potencialmente degradável e taxa de degradação, respectivamente. Empregando taxas de passagem de 2, 5 e 8\%/h para calcular a degradabilidade efetiva da proteína bruta, os autores obtiveram os valores de $80,5 \% ; 62,7 \%$ e $52,2 \%$ respectivamente.

VILELA (1994) determinou a degradabilidade "in situ" da matéria seca e da proteína bruta de vários alimentos em vacas alimentadas com diferentes rações. uando os animais receberam ração constituída de $60 \%$ de volumoso (silagem de capimelefante) e $40 \%$ de concentrado (milho, farelo de soja, uréia e suplemento mineral) foram obtidos os valores de $11,72 \%$ para a fração solúvel da matéria seca, de 79,98\% para a fração potencialmente degradável da matéria seca e $8 \% / \mathrm{h}$ para a taxa de desaparecimento da matéria seca do farelo de soja. Para a proteína bruta do farelo de soja estes valores foram de $17,4 \%, 80 \%$ e $10 \% / \mathrm{h}$. Para taxas de passagem de 2,5 e $8 \% / \mathrm{h}$ as degradabilidades efetivas da matéria seca foram $81,6 \% ; 68,3 \%$ e $59,4 \%$ e da proteína bruta $84,1 \% ; 70,7 \%$ e $61,8 \%$. 
ERASMUS et al. (1990a) avaliaram a degradabilidade "in situ" do sorgo grão com $10,8 \%$ de proteína bruta e sorgo grão com alto teor de tanino com $12,5 \%$ de proteína bruta, em vacas holandesas recebendo uma dieta com $45 \%$ de volumoso e $55 \%$ de concentrado, $15,2 \%$ de proteína bruta e $18,2 \%$ de fibra bruta. Os valores obtidos para as frações solúvel, potencialmente degradável, taxa de degradação e degradabilidade efetiva a diferentes taxas de passagem da proteína bruta são apresentados na tabela 7.

Tabela 7. Frações solúvel, potencialmente degradável, taxa de degradação e degradabilidade efetiva em diferentes taxas de passagem da proteína bruta do sorgo grão e sorgo grão com alto teor de tanino.

\begin{tabular}{|c|c|c|c|c|c|c|}
\hline \multirow[b]{2}{*}{ Alimentos } & \multicolumn{3}{|c|}{ Frações } & \multicolumn{3}{|c|}{$\begin{array}{c}\text { Degradabildade efetiva da } \\
\text { proteina }(\%)\end{array}$} \\
\hline & A & B & c & $0,02 *$ & $0,05^{*}$ & $0,08 *$ \\
\hline Sorgo grão & 23,4 & 74,9 & 4,6 & 76 & 60 & 51 \\
\hline Sorgo grão alto tanino & 12,5 & 32,1 & 2,5 & 69 & 52 & 45 \\
\hline
\end{tabular}

Fonte: Adaptado ERASMUS et al. (1990a).

A: fração solúvel (\%) B: fração potencialmente degradável (\%) c: taxa de degradação de B (\%/h)

* taxa de passagem assumida $(\% / \mathrm{h})$

A degradabilidade efetiva da proteína do sorgo grão calculada para taxa de passagem de $8 \% / \mathrm{h}$ foi de $51 \%$, enquanto que as degradabilidades médias por eles obtidas através da literatura foram de $48 \%, 50 \%$ e $52 \%$, muito próximas a $51 \%$.

WANDERLEY et al. (1992) avaliaram o efeito de extrusão, floculação e esmagamento do grão sobre a degradabilidade do amido do sorgo em vacas leiteiras recebendo $50 \%$ de feno de alfafa, $35 \%$ de grãos de cereais esmagados, $5 \%$ de sementes de algodão, $8 \%$ de concentrado protéico e $2 \%$ de suplemento mineral e vitamínico. Os autores observaram que o potencial máximo de degradação, em todos os tratamentos, ocorreu em torno de 36 horas de incubação, sendo a taxa de passagem de $6 \% / \mathrm{h}$. Houve efeito significativo dos tratamentos $(P<0,05)$, conforme os valores a seguir: 
fração solúvel, potencialmente degradável e taxa de degradação de $15,0 \%, 80,4 \%$ e 4,1 $\% / h$ para o grão extrusado, $27,6 \%, 93,5 \%$ e $7,5 \% / h$ para o grão floculado e $23,7 \%$, $77,0 \%$ e $3,5 \% / h$ para o grão esmagado, respectivamente.

VARGA \& HOOVER (1983) avaliaram a taxa de degradação da fibra em detergente neutro (FDN) da silagem de milho $(49,3 \%$ de FDN) e do farelo de soja ( $18,1 \%$ de FDN), e obtiveram 8,2 e $5,4 \% / h$, respectivamente.

A degradabilidade "in situ" da proteína bruta e matéria seca, da silagem de milho, sorgo grão e farelo de soja, em vacas gestantes e lactantes, foi estudada por VALADARES FILHO et al. (1991). Foram utilizadas vacas $7 / 8$ holandês-zebu após o pico de lactação, no terço final de gestação e 14 a 21 dias após o parto. Os animais receberam ração contendo $55 \%$ de silagem de milho e $45 \%$ de concentrado (milho, soja, uréia e suplemento mineral). Os valores de degradabilidade efetiva estimados da matéria seca e proteína bruta para os animais em diferentes fases são apresentados na tabela 8 . Os autores elaboraram uma equação geral abrangendo todas as fases e testaram as taxas de passagem de 2,5 e $8 \% / \mathrm{h}$. Os valores obtidos de degradabilidade efetiva da proteína bruta foram $59,2 \% ; 47,7 \%$ e $43,7 \%$ para a silagem de milho; $83,2 \% ; 61,5 \%$ e $50,6 \%$ para o farelo de soja, e $48,1 \% ; 29,2 \%$ e $22,6 \%$ para o sorgo grão em taxas de passagem de 2,5 e $8 \% / h$, respectivamente

Tabela 8. Degradabilidade efetiva estimada da matéria seca e proteína bruta, para vacas $7 / 8$ holandês-zebu em diferentes fases.

\begin{tabular}{|c|c|c|c|c|c|c|}
\hline \multirow[t]{2}{*}{ Alimento } & \multicolumn{3}{|c|}{$\begin{array}{c}\text { Degradabilidade da Proteína } \\
\text { Bruta* }(\%) \\
\end{array}$} & \multicolumn{3}{|c|}{$\begin{array}{c}\text { Degradabildade da Matéria } \\
\text { Seca* }(\%)\end{array}$} \\
\hline & G & $\mathrm{Ll}$ & $\mathrm{L} 2$ & G & $\mathrm{L} 1$ & $\mathrm{~L} 2$ \\
\hline Silagem de milho & 53,6 & 50,1 & 47,7 & 39,7 & 36,0 & 33,4 \\
\hline Farelo de soja & 73,9 & 67,0 & 61,5 & 76,7 & 70,9 & 66,3 \\
\hline Sorgo & 38,9 & 33,2 & 29,2 & 49,2 & 42,4 & 37,4 \\
\hline
\end{tabular}

Fonte: VALADARES FILHO et al. (1991).

G: terço final da gestação $\quad$ L1: 14 a 21 dias após o parto

* taxas de passagem assumidas: $\mathrm{G}=3 \% / \mathrm{h} ; \mathrm{Ll}=4 \% / \mathrm{h} ; \mathrm{L} 2=5 \% / \mathrm{h}$

L2: após o pico da lactação 
A degradabilidade ruminal da silagem de milho, do farelo de soja e do sorgo grão em novilhos da raça holandesa recebendo como volumoso silagem de milho (60\%) e como concentrado farelo de soja mais sorgo moído (40\%) foi estudada por SCHALCH \& ANDRADE (1992). A silagem apresentava 7,73\% de proteína bruta e o farelo de soja e o sorgo grão $53,6 \%$ e 9,41\%, respectivamente. A degradação em 24 horas da silagem de milho foi $24,48 \%$, do farelo de soja $28,1 \%$ e do sorgo moído $10,78 \%$.

VALADARES FILHO (1994) fez uma coletânea de diversos trabalhos que avaliaram a degradação efetiva "in situ" da matéria seca e proteína da silagem de milho, do farelo de soja e do sorgo grão. Os dados levantados pelo autor encontram-se na tabela 9 .

Tabela 9. Degradabilidade efetiva da matéria seca e proteína bruta da silagem de milho, farelo de soja e sorgo grão em diferentes taxas de passagem e estimativas de coeficientes para degradabilidade da proteína bruta (valores médios obtidos de diversos autores).

\begin{tabular}{|c|c|c|c|c|c|c|c|c|c|}
\hline \multirow{2}{*}{ Alimentos } & \multicolumn{3}{|c|}{$\begin{array}{l}\text { Degrad. efetiva da } \\
\text { matéria seca (\%) }\end{array}$} & \multicolumn{3}{|c|}{$\begin{array}{l}\text { Degrad. efetiva da } \\
\text { proteína bruta (\%) }\end{array}$} & \multicolumn{3}{|c|}{$\begin{array}{l}\text { Coeficientes p/ } \\
\text { degrad. prot. bruta }\end{array}$} \\
\hline & 2 & 5 & 8 & 2 & 5 & 8 & A & B & c \\
\hline Silagem de milho & 45,1 & 33,4 & 28,6 & 59,2 & 47,7 & 43,7 & 35,0 & 60,1 & 1,34 \\
\hline Farelo de soja & 82,4 & 67,0 & 57,8 & 82,6 & 65,5 & 55,6 & 20,2 & 77,0 & 6,62 \\
\hline Sorgo grão & 59,2 & 37,4 & 28,5 & 48,1 & 29,2 & 22,6 & 10,0 & 85,0 & 1,49 \\
\hline
\end{tabular}

Fonte: Adaptado VALADARES FILHO (1994).

A: fração solúvel (\%)

c:taxa de degradação de B $(\% / \mathrm{h})$

B: fração potencialmente degradável (\%)

2, 5 e 8: taxas de passagem assumidas $(\% / \mathrm{h})$ 


\section{MATERIAL E MÉTODOS.}

\subsection{Animais e manejo.}

Foram utilizados 4 bovinos machos da raça nelore, com idade aproximada de 36 meses e peso médio de $520 \mathrm{~kg}$. Os animais foram submetidos a cirurgia de implantação das fistulas ruminais flexíveis com diâmetro interno de $12 \mathrm{~cm}$. Após receberem cuidados pós operatórios e estarem recuperados do processo cirúrgico é que se iniciou o período de adaptação às dietas para posterior condução do ensaio de degradação.

Antes de se iniciar o período de adaptação, procedeu-se a vacinação, e vermifugação para a eliminação de ecto e endoparasitos.

Os animais permaneceram confinados em baias individuais onde receberam alimentação individual.

\subsection{Dietas utilizadas.}

Utilizaram-se 2 dietas com diferentes níveis de concentrado para o estudo da degradação "in situ", sendo:

Dieta 1 . $-80 \%$ volumoso $+20 \%$ concentrado.

Dieta 2 . - $60 \%$ volumoso $+40 \%$ concentrado.

Sal mineral e água foram fornecidos à vontade.

Como volumoso foi utilizada a silagem de milho. 
Os ingredientes utilizados no preparo do concentrado foram o farelo de soja, farelo de algodão, sorgo grão e o milho grão.

As dietas foram ajustadas às exigências dos animais para ganho diário de $0,6 \mathrm{~kg}$, utilizando-se o CNCPS. Dietas para nível de manutenção não proporcionavam ajustes adequados ao ambiente ruminal de acordo com o modelo, desta forma optou-se por ajustá-las para ganho.

A descrição das dietas é apresentada na tabela 10, e a avaliação da dieta segundo o CNCPS é apresentada na tabela 11.

Tabela 10. Dietas fornecidas aos animais para determinação da degradação "in situ" dos alimentos estudados.

$\%$ na dieta

\begin{tabular}{cccccc}
\cline { 2 - 5 } Dieta & $\begin{array}{c}\text { Silagem de } \\
\text { milho }\end{array}$ & $\begin{array}{c}\text { Farelo de } \\
\text { soja }\end{array}$ & $\begin{array}{c}\text { Farelo de } \\
\text { algodão }\end{array}$ & Milho & Sorgo \\
\hline Dieta 1 & 82,0 & 3,6 & 3,6 & 5,4 & 5,4 \\
Dieta 2 & 61,0 & 3,9 & 3,9 & 15,6 & 15,6 \\
\hline
\end{tabular}

Tabela 11. Avaliação das dietas fornecidas aos animais segundo o CNCPS (FOX et al.,1990).

\begin{tabular}{ccccccccc}
\hline Dieta & $\begin{array}{c}\text { MS } \\
(\%)\end{array}$ & $\begin{array}{c}\text { PB } \\
(\%)\end{array}$ & $\begin{array}{c}\text { Pdegr. } \\
(\% \mathrm{~PB})\end{array}$ & $\begin{array}{c}\text { EM } \\
(\mathrm{mcal} / \mathrm{dia})\end{array}$ & $\begin{array}{c}\text { NDT } \\
(\%)\end{array}$ & $\begin{array}{c}\text { FDN } \\
(\%)\end{array}$ & $\begin{array}{c}\text { IMS } \\
(\mathrm{kg} / \mathrm{dia})\end{array}$ & $\begin{array}{c}\text { Ganho } \\
(\mathrm{kg} / \mathrm{dia})\end{array}$ \\
\hline Dieta 1 & 74,7 & 11,1 & 75,2 & 19,2 & 73,0 & 38,2 & 7,6 & 0,54 \\
Dieta 2 & 77,9 & 12,1 & 72,7 & 20,8 & 78,0 & 29,8 & 7,7 & 0,66 \\
\hline
\end{tabular}




\subsection{Obtenção dos alimentos estudados.}

Houve inicialmente a preocupação em se obter amostras de alimentos que fossem representativos, em termos médios, daqueles usuais no preparo de rações. Para tanto, o farelo de soja a ser incubado foi obtido coletando-se amostras de três origens diferentes, entre fornecedores do produto e entidades que se utilizam do mesmo (AGROCERES, Rio Claro-SP; RAÇÕES FRI-RIBE, Ribeirão Preto-SP; ESALQ-USP, Piracicaba-SP, sendo este último de diversas origens).

Tomaram-se amostras de diversos sacos, sendo devidamente homogeneizadas, e destas foi posteriormente armazenada adequadamente uma alíquota de $1,5 \mathrm{~kg}$, quantia julgada suficiente para a execução do ensaio de degradação "in situ". Somente após análise os farelos de igual teor de proteína foram misturados.

$O$ procedimento foi o mesmo para o sorgo grão, sendo este proveniente das fábricas da FRI-RIBE (Ribeirão Preto-SP) e da GUABI (Orlândia-SP).

A silagem de milho utilizada foi de origem da própria ESALQ. O material foi obtido, coletando-se amostras em vários pontos do silo reservado para a alimentação dos animais durante o período experimental. $O$ material ensilado era proveniente de 17 variedades de milho. As sementes das variedades foram distribuídas no campo aleatóriamente, proporcionando a obtenção de uma boa mistura das variedades por ocasião do processo de ensilagem. Foram tomadas amostras de diferentes partes do silo, totalizando $10 \mathrm{~kg}$. As amostras foram devidamente homogeneizadas e todo o material foi secado a $55^{\circ} \mathrm{C}$ por 72 horas em estufa com aeração forçada. Armazenou-se uma alíquota de $2,0 \mathrm{~kg}$ para o ensaio de degradação "in situ". A silagem utilizada apresentou aproximadamente $35 \%$ de grãos na matéria seca.

\subsection{Determinação da degradabilidade " in situ ".}

A determinação das degradabilidades efetiva e potencial das frações estudadas foi obtida pela diferença entre as quantidades incubadas e as dos resíduos. 
A degradabilidade potencial (p) foi calculada utilizando-se o modelo matemático proposto por MEHREZ \& ORSKOV (1977):

$$
p=a+b\left(1-e^{-c t}\right)
$$

sendo:

$$
\begin{aligned}
& \mathrm{p}=\text { degradabilidade potencial }, \text { no tempo } t(\%) ; \\
& \mathbf{a}=\text { fração solúvel }(\%) ; \\
& \mathrm{b}=\text { fração potencialmente degradável }(\%) ; \\
& \mathrm{c}=\text { taxa de degradação da fração } \mathrm{b}(\% / \mathrm{h}) . \\
& \mathbf{t}=\text { tempo de incubação }(\mathrm{h}) .
\end{aligned}
$$

A degradabilidade efetiva (d) foi calculada segundo o modelo matemático proposto por ORSKOV E McDONALD (1979):

$$
\mathrm{d}=\mathrm{a}+((\mathrm{b} \times \mathrm{c}) /(\mathrm{c}+\mathrm{k}))
$$

onde $k$ = taxa de passagem da fase sólida obtida para cada animal e dieta, em \%/ hora.

A fração "a" foi obtida através da lavagem inicial dos sacos contendo alimento, antes de serem submetidos a degradação; "b" obtida por $(100-(a+c))$ e a "c" através da regressão do logarítimo natural $(\ln )$ do resíduo potencialmente degradável.

O tempo de colonização ("lag time") foi calculado segundo o modelo proposto por McDONALD (1981):

$$
\left(\ln R P D t_{0}-\ln R P D t\right) / c
$$

onde:

$$
\begin{aligned}
& \begin{aligned}
\ln \text { RPD } t_{0}= & \text { logaritimo natural do resíduo potencialmente degradável no } \\
& \text { tempo } 0 \text { hora. }
\end{aligned} \\
& \begin{aligned}
\ln \text { RPD } t= & \text { logaritimo natural do resíduo potencialmente degradável no } \\
& \text { último tempo utilizado de incubação. }
\end{aligned} \\
& c=\text { taxa de degradação da fração } b .
\end{aligned}
$$

As frações a e b levando em consideração o tempo de colonização foram calculadas segundo McDONALD (1981) e SUSMEL et al. (1990). O valor de a, denominado de a', foi obtido considerando-se solúvel a porção do alimento até o tempo de colonização, e o valor de b denominado de b' obtido por: $\left((a+b)-a^{\prime}\right)$. 


\subsubsection{Preparo do material.}

A silagem de milho incubada foi moída em peneira de $5 \mathrm{~mm}$, o farelo de soja e o sorgo grão passaram por peneira de $2 \mathrm{~mm}$.

Os alimentos foram introduzidos em sacos de $7 \times 14 \mathrm{~cm}$ de área livre, confeccionados em náilon ( $100 \%$ poliamida, resistente a alta temperatura, não resinado), selados a quente em máquina seladora de sacos plásticos. $\mathrm{O}$ tecido utilizado apresentava abertura de poro entre 40 e $50 \mu$ e aproximadamente $30 \%$ de área livre.

Foram colocadas em torno de 5,5 $\mathrm{g}$ de amostra por saco, o que proporcionou uma relação aproximada de matéria seca de $26 \mathrm{mg} / \mathrm{cm}^{2}$ de área do saco.

\subsubsection{Período de coleta.}

O ciclo de coleta foi constituído por 2 períodos de degradação "in situ", cada um constituído de 21 dias de adaptação às dietas e 3 dias de coleta, onde os 3 alimentos estudados foram submetidos às duas dietas em 4 animais.

Foram colocados 89 sacos de náilon por animal, correspondentes a 3 repetições para a silagem de milho, 5 para o farelo de soja e 5 para o sorgo grão, até o tempo de incubação de 12 horas para o volumoso e de 4 horas para os concentrados. A partir destes tempos o número de sacos foi aumentado em número de 2 para cada tempo de incubação no rúmen, para se obter quantidade de resíduo suficiente para as análises desejadas nos maiores tempos de incubação.

Foi também introduzido um saco sem amostra (branco) por tempo de degradação visando possíveis correções.

Os tempos de incubação no rúmen utilizados foram de $3,6,12,24,36,48$ e 72 horas para a silagem do milho e de $2,4,6,12,24$ e 48 horas para o farelo de soja e o sorgo grão.

Os sacos de náilon contendo as amostras foram previamente lavados em água a $39{ }^{\circ} \mathrm{C}$ por 15 minutos com leve agitação, para remover a fração solúvel. Após a etapa de lavagem, foram secados a $55^{\circ} \mathrm{C}$ por 72 horas em estufa com aeração forçada. 
O sacos referentes ao tempo zero somente foram lavados e secados, uma vez que não foram incubados.

O procedimento de introdução dos sacos no rúmen foi nos tempos sucessivos pré-estabelecidos, e todos retirados simultâneamente.

Retirados do rúmen, foram colocados em água com gelo por aproximadamente 2 horas, em seguida lavados em máquina de lavar com agitação e fluxo de água constante. $\mathrm{O}$ ponto final de lavagem considerado ideal foi monitorado coletando-se com um becker água do interior da máquina e observando-se sua coloração, considerado ideal quando a água se tornasse apenas levemente turva.

Em seguida os sacos foram secados a $55^{\circ} \mathrm{C}$ por 72 horas em estufa com aeração forçada.

\subsection{Frações analisadas.}

As amostras de alimento e os resíduos da degradação foram moídos em peneira de $1 \mathrm{~mm}$ para serem submetidos às análises.

Nos alimentos foram determinados: matéria seca (MS), extrato etéreo (EE), cinzas (Cz) e nitrogênio total (NT), segundo os métodos da A.O.A.C. (1970); fibra em detergente ácido (FDA), fibra em detergente neutro (FDN), nitrogênio insolúvel em detergente ácido (NIDA), nitrogênio insolúvel em detergente neutro (NDN) e lignina (LIG), segundo VAN SOEST et al. (1991); amido (AM), segundo MACRAE \& ARMSTRONG (1968) e POORE et al (1989), utilizando-se as adaptações descritas por PEREIRA \& ROSSI Jr. (1994); nitrogênio solúvel (Nsol) e nitrogênio não protéico (NNP), segundo KRISHNAMOORTHY et al. (1982) adaptado por PEREIRA E ROSSI Jr. (1994).

As repetições dentro de um mesmo tempo de incubação, de cada animal, foram unidas para se obter quantidade suficiente de resíduo para as análises. No resíduo da degradação "in situ" foram determinados nitrogênio total, fibra em detergente neutro, nitrogênio insolúvel em detergente neutro e amido. 


\subsection{Determinação das taxas de passagem das dietas.}

A determinação das taxas de passagem da fase sólida das dietas foi feita seguindo-se a técnica da fibra marcada com cromo mordente, descrita por UDEN et al. (1980). Sendo marcada somente a silagem de milho, sem os grãos, para a determinação da taxa de passagem das dietas.

Foram coletadas amostras de fezes e conteúdo ruminal. Os horários de coleta de fezes foram: $0,12,16,20,24,28,32,36,42,48,54,60,72,84,96$ e 120 horas após a introdução da fibra marcada com cromo mordente no rúmen; o conteúdo ruminal foi coletado $0,4,8,12,16,20,24,28,32,36,42,48,54,60,72$ e 84 horas após a introdução da fibra marcada com cromo mordente no rúmen.

A determinação do cromo nas fezes e rúmen foi feita segundo PEREIRA \& ROSSI Jr. (1994).

A taxa de passagem foi obtida através da regressão do logarítimo natural (ln) das concentrações de cromo nas fezes correspondentes aos tempos de coleta.

\subsection{Análise estatística.}

O efeito da dieta sobre os coeficientes da equação de MERHEZ E ORSKOV (1977) e os valores de degradabilidade potencial e efetiva foram analisados utilizando-se o delineamento em blocos casualizados, cada animal constituindo um bloco.

Através de esquema fatorial foram avaliados:

1) o efeito de dieta em relação a cada um dos coeficientes, para cada alimento estudado.

2) o efeito de dieta e uso ou não do tempo de colonização ("lag time"), sobre as degradabilidades potencial e efetiva, de cada alimento.

As análises estatísticas utilizaram os sistemas SAS e SANEST. 


\section{RESULTADOS E DISCUSSÃO.}

\subsection{Análises dos alimentos.}

As análises dos alimentos seguiram o esquema proposto pelo CNCPS, onde foram analisados os constituintes da fração protéica e de carboidratos.

Os teores de matéria seca, gordura, cinzas, os constituintes das frações protéicas e de carboidratos da silagem de milho, farelo de soja e sorgo grão encontram-se expressos na tabela 12.

\subsubsection{Silagem de milho.}

A silagem de milho apresentou $41,94 \%$ de MS e continha $35 \%$ de grãos, tendo sido considerada de qualidade média a boa.

O teor protéico foi de $7,13 \%$, muito próximo ao valor $8,3 \%$ assumido pelo CNCPS para silagem com $35 \%$ de grãos. O valor de Psol foi de $41,39 \%$, e o assumido pelo modelo $50 \%$.

A solubilidade da proteína proporcionada pela lavagem dos sacos antes da colocação no rúmen foi de $62,61 \%$ (tabela 16). Não houve, portanto, correspondência éntre os valores obtidos no ensaio de degradação "in situ" e o obtido através da análise bromatológica $(41,39 \%$ ), ao contrário do que seria esperado. Tal diferença pode ser porque no processo de lavagem ocorre perda de material, levando consigo parte dos componentes do alimento, apesar da malha do tecido utilizado ter sido considerada ideal. 
Tabela 12. Teores da matéria seca, gordura, cinzas e constituintes das frações protéicas e dos carboidratos da silagem de milho, farelo de soja e sorgo grão.

\begin{tabular}{llccc}
\hline & & \multicolumn{3}{c}{ Alimentos } \\
\cline { 3 - 5 } Fração & Unid. & Silagem de milho & Farelo de soja & Sorgo grão \\
\hline MS & $\%$ & 41,94 & 89,03 & 89,00 \\
EE & \%MS & 2,68 & 1,65 & 4,04 \\
Cz & \%S & 8,26 & 6,46 & 1,71 \\
PB & \%MS & 7,13 & 51,39 & 9,19 \\
Psol & \%B & 41,39 & 35,89 & 12,98 \\
NNP & \%Psol & 97,83 & 11,07 & 41,90 \\
NIDN & \%PB & 21,27 & 4,53 & 17,13 \\
NIDA & \%PB & 12,57 & 2,36 & 16,61 \\
CHO & \%MS & 84,58 & 52,82 & 97,42 \\
CNS & \%MS & 45,78 & 42,00 & 86,47 \\
CNS* & \%CHO & 54,12 & 79,52 & 88,76 \\
AM & \%MS & 27,23 & 2,82 & 65,36 \\
AM & \%CNS & 59,47 & 6,71 & 75,59 \\
FDN & \%MS & 39,28 & 11,70 & 11,15 \\
FDA & \%MS & 23,30 & 9,51 & 4,91 \\
LIG & \%FDN & 6,75 & 2,82 & 3,07 \\
\hline
\end{tabular}

MS: Matéria seca; EE: extrato etéreo; Cz: cinzas; PB: proteína bruta; Psol: proteína solúvel; NNP: nitrogênio não protéico; NIDN: nitrogênio insolúvel em detergente neutro; NIDA: nitrogênio insolúvel em detergente ácido; CHO: carboidratos; CNS: carboidratos não estruturais; AM: amido; FDN: fibra em detergente neutro; FDA: fibra em detergente ácido;LIG: lignina.

* Valores estimados através do CNCPS.

Quanto ao NNP, o valor obtido de $97,83 \%$ constata o que já era esperado, pois pelo CNCPS a Psol é considerada na sua totalidade como NNP para silagens com $35 \%$ de grãos. Os valores de NIDN (21,27 \%) e de NIDA (12,57 \%) foram superiores aos assumidos pelo modelo, que são de $16 \%$ e $9 \%$, respectivamente. 
O valor de NIDA encontrado é proximo ao valor de $15 \%$ apresentado por VALADARES FILHO (1994).

Considerando-se as divisões assumidas pelo CNCPS para a fração protéica, foram obtidos os seguintes valores para a silagem de milho: $A=40,4 \%, B 1=1,00 \%$, $\mathrm{B} 2=37,3 \%$ e $\mathrm{B} 3=8,70 \%$ e $\mathrm{C}=12,6 \%$. $\mathrm{O}$ valor de $\mathrm{B} 2$ corresponde à proteína potencialmente degradável no rúmen. No estudo de degradação "in situ" a fração proteíca potencialmente degradável $\mathrm{B}$ apresentou valores próximos a $36 \%$ nas duas dietas avaliadas (tabela 16).

O modelo considera B2 de disponibilidade média e com taxa de degradação próxima à de passagem (SNIFFEN et al., 1992). Neste estudo a taxa de degradação da fração potencialmente degradável (B) da proteína foi em torno de $3,5 \%$, em ambas dietas avaliadas (tabela 16), semelhante à taxa de passagem calculada através de amostras de fezes que foi em torno de 3,5\%, nas duas dietas avaliadas (tabela 13).

Portanto, observa-se boa relação entre os valores obtidos pelas análises da silagem e os valores extraídos no ensaio de degradação "in situ", para as divisões da fração protéica assumidas pelo CNCPS.

O teor de LIG determinado (6,75\%) foi inferior a 8,7\% assumido pelo CNCPS, mas dentro da faixa de 5 a $25 \%$ considerada possível por SNIFFEN et al. (1992). 0 mesmo ocorreu para o FDN e conteúdo de AM que foram de $39,28 \%$ e $59,47 \%$ dos CNS, em relação aos valores assumidos pelo CNCPS de $46 \%$ e $100 \%$, respectivamente.

Diferenças no conteúdo de FDN estão relacionadas com o estágio de maturação da planta por ocasião de sua colheita para ensilagem. Portanto, os valores da literatura e os assumidos pelo CNCPS são de difícil comparação, se não houver uma boa caracterização da fase de corte da forragem, além de variedade e outros fatores.

Para o AM os valores discrepantes podem estar relacionados com a metodologia de análise. Os valores da literatura como os apresentados na revisão de PATTON (1994), no qual o AM corresponde a $39,4 \pm 9,5 \%$ da MS, são superiores aos encontrados neste trabalho de $27,23 \%$ da MS. 
No caso do AM metodologias como as que empregam o reagente de Fehling podem estar na verdade determinando os açúcares redutores totais que fazem parte dos CNS e considerando todos como se fossem amido. A metodologia empregada neste trabalho, que obtém o teor de amido através do conteúdo de glucose por método enzimático, parece ser a mais correta.

O CNCPS assume que todo CNS seja amido, o que não corresponde à realidade, pois sempre existem açúcares nos CNS da silagem. Portanto valor de 59,47\% obtido parece ser mais coerente.

Analogamente à proteína, o CNCPS assume divisão dos carboidratos em frações, das quais A corresponde aos açúcares, a qual, entretanto não foi determinada neste trabalho. Poderia, porém, ser inferida, uma vez que as demais frações B1, B2 e C puderam ser calculadas, sendo: $\mathrm{B} 1=38,0 \%, \mathrm{~B} 2=39,0 \%$ e $\mathrm{C}=7,5 \%$.

Quando os resultados do estudo de degradação forem apresentados será feita uma relação da taxa de desaparecimento assumida para cada divisão e as encontradas no presente estudo.

\subsubsection{Farelo de soja.}

O teor protéico do farelo de soja foi de $51,39 \%$.

O teor de Psol determinado, 35,89 \%, foi 79,45\% superior ao valor assumido pelo CNCPS, de $20 \%$, para farelo de soja apresentando $49 \%$ de proteína bruta. Apesar de tão contrastante, este valor parece correto ao se comparar o valor da fração solúvel da proteína bruta, próximo a $40 \%$ nas duas dietas, obtido no ensaio de degradação "in situ" (tabela 16).

Outro valor que não correspondeu aos descritos pelo CNCPS foi o obtido para o NNP. O CNCPS assume que 55\% da Psol é NNP, para o farelo de soja com 49\% de proteína. Neste trabalho foi encontrado $11,07 \%$ de Psol como NNP. Tratando-se de farelo de soja, $55 \%$ de Psol como NNP parece ser muito elevado. 
Os valores de NIDN e NIDA obtidos (4,53 e 2,36 \%) se apresentaram bem próximos aos do CNCPS (5 e $2 \%$ ). 0 valor médio de NIDA apresentado por VALADARES FILHO (1994), é de 4,2\%.

Como foi feito para a silagem de milho, estabelecendo-se uma relação entre as divisões assumidas da fração protéica pelo CNCPS, tem-se os seguintes valores para o caso do farelo de soja: $\mathrm{A}=4,0 \%, \mathrm{~B} 1=31,9 \%, \mathrm{~B} 2=59,6 \%$, B3 $=2,0 \%$ e $\mathrm{C}=2,3 \%$. $\mathrm{O}$ valor da fração B2 foi muito próximo ao encontrado para a fração potencialmente degradável da proteína bruta (b) do farelo de soja no ensaio de degradação "in situ", aproximadamente $59 \%$ (tabela 16).

O teor de LIG determinado foi de $2,82 \%$, próximo a $2,5 \%$ assumido pelo CNCPS. $O$ teor obtido de FDN foi de $11,7 \%$, e o assumido pelo CNCPS, para o farelo de soja com $49 \%$ de PB é de $14,0 \%$.

Para o AM o valor determinado de 6,71 \% dos CNS não se relacionou com o de $90 \%$ assumido pelo CNCPS. É necessário maior número de determinações para estabelecer o valor correto, além de uma padronização da metodologia de análise. Quando comparado com o valor encontrado por PATTON (1994) em sua revisão (12,9 $\%$ da MS), o valor de $2,82 \%$ da MS obtido neste trabalho foi muito inferior.

\subsubsection{Sorgo grão.}

O teor protéico determinado para o sorgo grão, 9,19\%, foi inferior ao assumido pelo CNCPS (12,4\%).

Quanto à Psol o valor obtido de 12,98 \% é próximo ao assumido pelo CNCPS (12\%). Porém é inferior comparado ao valor $(23,91 \%)$ da fração solúvel da proteína, obtida no estudo de degradação "in situ", reforçando a hipótese de perda de material através da malha do tecido, mais pronunciada com o sorgo que para os demais alimentos. 
O NNP de $41,9 \%$ foi $27 \%$ superior ao assumido pelo CNCPS, de $33 \%$.

Considerando as subdivisões da fração protéica do CNCPS, a proteína do sorgo é dividida em: $\mathrm{A}=5,4 \%, \mathrm{~B} 1=7,6 \%, \mathrm{~B} 2=70,0 \%, \mathrm{~B} 3=0,4 \%, \mathrm{C}=16,6 \%$. Também para o sorgo grão o valor obtido para B2 (70 \%) correspondeu ao encontrado para a fração potencialmente degradável da proteína bruta (B) que foi de aproximadamente $72 \%$ na duas dietas avaliadas (tabela 16).

Os valores de NIDN e NIDA de $17,13 \%$ e $16,61 \%$ também foram superiores aos assumidos pelo CNCPS, de 10 e $5 \%$. Um fato a ressaltar é que neste trabalho o resultado obtido mostra que praticamente todo o nitrogênio presente no NDF está na forma indisponível (NIDA), sendo que se esperava que pelo menos parte deste fosse disponível.

O teor de LIG foi de 3,07\%, aproximadamente $50 \%$ inferior a $6,09 \%$ assumido pelo CNCPS. $O$ valor de FDN $(11,15 \%)$ também foi inferior ao assumido pelo CNCPS (23\%).

O valor de AM determinado de 75,59\% do CNS foi inferior ao assumido pelo CNCPS que é de $90 \%$. Quando comparado com outros valores como os de PATTON (1994) e HIBBERD et al. (1982), que oscilaram na faixa de 61 a $79 \%$, o valor obtido de AM de $65,38 \%$ da MS se apresenta compatível. No trabalho de HIBBERD et al. (1982) foi utilizado o método de determinação dos polímeros de glucose para se determinar o teor de amido, como neste trabalho.

Em relação às divisões propostas pelo $\mathrm{CNCPS}$, temos para a fração de carboidrato do sorgo grão os seguintes valores: $\mathrm{B} 1=68,9 \%, \mathrm{~B} 2=10,6 \%$ e $\mathrm{C}=0,8 \%$. A fração A não foi determinada analiticamente. É necessário verificar se os teores de açúcares correspondem ao valor que resta para completar a fração carboidrato do sorgo grão e demais alimentos avaliados. 


\subsection{Taxa de passagem das dietas.}

As taxas de passagem das dietas estimadas a partir de amostras de fezes e conteúdo ruminal, nas duas dietas avaliadas, encontram-se na tabela 13.

Tabela 13. Taxas de passagem $(\% / h)$ estimadas a partir de amostras de fezes e conteúdo ruminal, nas duas dietas avaliadas.

\begin{tabular}{cccccc}
\hline & \multicolumn{2}{c}{ Fezes } & & \multicolumn{2}{c}{ Rúmen } \\
\cline { 2 - 3 } \cline { 5 - 6 } Animal & Dieta 1 & Dieta 2 & & Dieta 1 & Dieta 2 \\
\hline Animal 1 & 4,18 & 4,04 & & 4,77 & 4,81 \\
Animal 2 & 5,08 & 4,40 & & 5,51 & 6,24 \\
Animal 3 & 3,01 & 2,53 & & 3,60 & 3,73 \\
Animal 4 & 2,69 & 2,67 & & 4,88 & 3,79 \\
\hline Média & 3,74 & 3,41 & & 4,69 & 4,64 \\
\hline
\end{tabular}

D1: Dieta com $80 \%$ de volumoso e $20 \%$ de concentrado.

D2: Dieta com $60 \%$ de volumoso e $40 \%$ de concentrado.

Um dos fatores a ser considerado antes da discussão dos resultados apresentados

é que, conforme descrito em material e métodos, somente a silagem foi marcada para fins de determinação da taxa de passagem da dieta.

Para a dieta 1 o coeficiente de variação foi mais elevado para amostras de fezes que de rúmen sendo $29,38 \%$ vs. $16,98 \%$. Porém na dieta 2 estes valores ficaram muito próximos: $27,81 \%$ para as fezes e $25,30 \%$ para o rúmen.

Apesar da vạriação maior que ocorreu com a dieta 1 para as taxas de passagem determinadas através de amostras de fezes, os valores relativos as duas dietas através de coleta de fezes, foram utilizados para a determinação da degradabilidade efetiva. 
Alguns fatores levaram a este procedimento: 1) o conteúdo ruminal é de difícil homogeinização, o que diminui a confiança nas amostras coletadas, principalmente nos primeiros tempos de coleta; 2) os valores de taxas de passagem apesar de manterem certa proporcionalidade nas duas dietas, mostraram-se sempre superiores para o rúmen, enquanto que os dados relativos as fezes pareceram mais compatíveis com os da literatura (POORE, 1987 e SNIFFEN et al., 1992); 3) estudos já demostraram não haver diferenças entre os dois métodos de determinação, apesar das fezes estarem representando a passagem por todo o trato e não somente pelo rúmen.

Apesar do pouco número de repetições e da variação animal evidente, em relação à média, não houve efeito $(P>0,05)$ do nível de concentrado da dieta sobre a taxa de passagem. Talvez os níveis de concentrado tenham sido muito próximos, não permitindo diferenças evidentes entre as taxas de passagem.

Os dados apresentados, apesar da pouca diferença encontrada, demostram o que a literatura apresenta. No trabalho de COLUCCI (1982), o aumento no nível de forragem da dieta aumentou a taxa de passagem de concentrado e volumoso da dieta. Em estudo apresentado por OWENS E GOETSCH (1986), citados por POORE (1987), o aumento no nível de concentrado da dieta proporciona redução na taxa de passagem tanto de concentrado como de volumoso, conclusões também reforçadas no próprio estudo realizado por POORE (1987).

Para a dieta 2, os valores estimados de taxa de passagem por amostras de fezes ou de rúmen apresentaram correlação mais elevada $(0,93)$ do que para a dieta $1(0,66)$. No caso da dieta 2, o nível de concentrado mais elevado proporcionou melhor homogeinização do conteúdo ruminal, o que provávelmente reduziu o erro em relação às fezes pela coleta de uma amostra mais significativa em cada tempo de coleta, fato evidenciado pelos coeficientes de variação muito próximos em ambos os casos.

\subsection{Tempo de colonização (" lag time ").}

Os tempos de colonização (TC) da matéria seca dos alimentos estudados não apresentaram comportamento semelhante em ambas as dietas avaliadas (tabela 14). 
Tabela 14. Tempos de colonização" ("lag time") da matéria seca obtidos para a silagem de milho, farelo de soja e sorgo grão, nas dietas avaliadas.

\begin{tabular}{cccc}
\hline Dietas & Silagem de milho & Farelo de soja & Sorgo Grão \\
\hline Dieta 1 & $2,10^{\mathrm{a}}$ & $2,60^{\mathrm{a}}$ & $0,50^{\mathrm{a}}$ \\
Dieta 2 & $6,40^{\mathrm{b}}$ & $1,89^{\mathrm{a}}$ & $1,02^{\mathrm{b}}$ \\
\hline
\end{tabular}

Dieta 1: $80 \%$ de volumoso e $20 \%$ de concentrado.

Dieta 2: $60 \%$ de volumoso e $40 \%$ de concentrado.

* tempo de colonização em horas.

Valores seguidos por letras distintas, nas colunas, diferem entre si ao nível de $\mathrm{P}<0,05$.

Para a silagem de milho e sorgo grão houve efeito significativo $(P<0,05)$ das dietas avaliadas sobre o TC da matéria seca.

O TC da dieta 2 foi superior ao da dieta 1 para a silagem de milho e sorgo grão. Este fato pode ser explicado pela maior proporção de concentrado da dieta 2, que estaria reduzindo o número de bactérias celulolíticas e consequentemente proporcionando ligeiro atrazo no início do processo de degradação da silagem. Aumento linear no tempo de colonização da digestão da fibra também foi observado por MERTENS E LOFTEN (1980) à medida em que a proporção de amido da dieta era aumentado.

Segundo BÜRGER et al. (1990), dietas exclusivas de volumoso, ou com alta proporção deste, aumentam a atividade de bactérias celulolíticas.

Apesar do princípio citado anteriormente, de que a dieta 2 estaria tornando o ambiente ruminal mais propício ao desenvolvimento de bactérias que estariam atuando sobre a degradação dos concentrados (amilolíticas e proteolíticas), não houve efeito das dietas sobre o TC do farelo de soja $(P>0,05)$. 
O comportamento do sorgo grão foi diferente do farelo de soja. Houve efeito significativo da dieta sobre o TC da matéria seca $(\mathrm{P}<0,05)$, porém, a dieta 2 apresentou TC $50 \%$ superior ao da dieta $1(0,5 \mathrm{~h}$ vs. 1,02$)$.

Apesar de não ter sido detectado efeito animal quanto ao TC da matéria seca dos alimentos estudados, vale salientar que o coeficiente de variação apresentou-se elevado em ambas as dietas chegando a $51,08 \%$, para o farelo de soja na dieta 1 . Para os demais alimentos e dietas manteve-se na faixa de 22 a $38 \%$.

Estudos como os realizados por SUSMEL et al. (1990) tem apresentado TC distintos para cada uma das frações avaliadas, isto é, um para o FDN, outro para PB e assim sucessivamente. Esse critério não parece correto, porque uma vez iniciado o processo de degradação da matéria seca, todas as demais frações estariam sofrendo a mesma ação simultâneamente e não em tempos diferentes.

Neste estudo, o TC calculado para a MS foi mantido para o cálculo de degradabilidade efetiva e da taxa de degradação das demais frações analisadas, quando este (TC) foi considerado.

4.4. Frações solúvel, potencialmente degradável, indegradável e taxa de degradação da fração potencialmente degradável, dos componentes dos alimentos avaliados.

\subsubsection{Maténia seca.}

Os valores das frações solúvel, potencialmente degradável, indegradável e taxa de degradação da fração potencialmente degradável da matéria seca da silagem de milho, farelo de soja e sorgo grão, nas dietas avaliadas são apresentados na tabela 15 . 
Tabela 15. Frações solúvel (A), potencialmente degradável (B), indegradável (C) e taxa de degradação da fração potencialmente degradável (c) da matéria seca da silagem de milho, farelo de soja e sorgo grão, nas dietas avaliadas".

\begin{tabular}{|c|c|c|c|c|c|c|c|c|}
\hline \multirow{2}{*}{ Alimentos } & \multicolumn{2}{|c|}{$\mathrm{A}(\%)$} & \multicolumn{2}{|c|}{ B (\%) } & \multicolumn{2}{|c|}{$\mathrm{C}(\%)$} & \multicolumn{2}{|c|}{$\mathrm{c}(\% / \mathrm{h})$} \\
\hline & D1 & D2 & D1 & D2 & Dl & D2 & D1 & D2 \\
\hline Sil. de milho & $20,02^{\mathrm{a}}$ & $21,02^{b}$ & $56,06^{\mathrm{a}}$ & $52,39^{b}$ & 23,95 & 26,59 & 2,96 & 2,44 \\
\hline F. de soja & $37,34^{\mathrm{a}}$ & $35,30^{\mathrm{b}}$ & 62,07 & 61,82 & 0,85 & 2,64 & $8,83^{\mathrm{a}}$ & $7,23^{\mathrm{b}}$ \\
\hline Sorgo grão & 19,79 & 19,20 & $60,40^{\mathrm{a}}$ & $53,31^{b}$ & $19,82^{\mathrm{a}}$ & $26,99^{\mathrm{b}}$ & $2,92^{\mathrm{a}}$ & $3,75^{b}$ \\
\hline
\end{tabular}

D1: Dieta com $80 \%$ de volumoso e $20 \%$ de concentrado.

D2: Dieta com $60 \%$ de volumoso e $40 \%$ de concentrado.

" Os valores das frações foram cal culados sem levar em consideração o tempo de colonização ("lag time"). Valores seguidos de letras distintas, nas linhas, para uma mesma fração, diferem entre si ao nível de $\mathrm{P}<0,05$.

Para as frações apresentadas na tabela 15 houve efeito animal $(P<0,15)$ somente para a taxa de degradação (c), sendo o coeficiente de variação de 15,8 \%. $O$ coefíciente de variação das frações $\mathrm{A}, \mathrm{B}$ e $\mathrm{C}$ foram baixos entre 2 e $4 \%$.

O efeito de dieta encontrado para a fração $A$ não possue significado, uma vez que tratou-se apenas de períodos distintos de lavagem. Tendo sido A definido como a porção solúvel em água a $39^{\circ} \mathrm{C}$ sob leve agitação por 15 minutos, era de se esperar que não houvessem diferenças entre períodos de lavagem.

Fica evidenciado que a manipulação dos sacos, antes do início do período experimental, possui influência sobre os resultados, confirmando trabalhos citados (NOCEK , 1985 e NOCEK, 1988)

Para a fração potencialmente degradável $(B)$ houve efeito de dieta $(P<0,05)$ para a silagem de milho e o sorgo grão, sendo que nos dois alimentos o nível de concentrado de $40 \%$ (dieta 2 ) reduziu seu valor. A redução de B foi mais pronunciada para o sorgo grão $(11,7 \%)$ que para a silagem de milho $(6,5 \%)$. 
A redução da fração $B$ da silagem de milho ocorreu porque o aumento do nível de concentrado na dieta ocasionou uma provável seleção dos microrganismos ruminais, reduzindo o número de bactérias celulolíticas, e consequentemente reduzindo a porção de material a ser degradado no rúmen. Porém o efeito deveria ter ocorrido no sentido inverso para o sorgo grão, com aumento da fração B.

O decréscimo no número de bactérias celulolíticas devido a competição com as bactérias amilolíticas, o baixo $\mathrm{pH}$ associado a rápida digestão do amido e o aumento na taxa de diluição do rúmen, são aceitos por diversos autores como os principais fatores que afetam a digestão, principalmente da fibra, em dietas com altos níveis de concentrado ( HOOVER, 1986, POORE, 1987 e PETIT, 1994)

Houve efeito de dieta $(P<0,05)$ na fração $C$ somente para o sorgo grão.

O efeito da dieta foi muito variável sobre o valor de (c) para os alimentos estudados.

Para a silagem de milho não houve efeito significativo de dieta sobre a taxa de degradação (c) da matéria seca, porém, uma redução de 18,1 \% significativa de (c) $(P<0,05)$ da dieta 2 , em relação a dieta 1 , foi observada para 0 farelo de soja.

Para o sorgo grão o efeito foi inverso ao observado para o farelo de soja. Houve aumento significativo $(\mathrm{P}<0,05)$ no valor de (c) na dieta 2 de $28,4 \%$. Nota-se que para o sorgo grão ocorreu um aumento na taxa de degradação, apesar da redução da porção potencialmente degradável.

O efeito animal observado para (c) pode ser indicativo de que a utilização da média dos quatro animais não foi bom procedimento. Os resultados podem não condizer com a situação real, e por isso, mostraram-se tão variados quanto ao efeito da dieta.

Porém vale salientar que a proporção de milho e de sorgo na dieta 1 era muito próxima à proporção de farelo de soja e de algodão. Na dieta 2 os níveis de milho e de sorgo foram elevados de três vezes em relação à dieta, enquanto que a proporção de farelo de soja e de algodão se manteve igual (tabela 10). 
O aumento na taxa de diluição, causado pelo aumento no nível de concentrado da dieta, estaria reduzindo a porção potencialmente degradável do sorgo. Porém, o aumento na atividade amilolítica no rúmen, causado pelo aumento do nível de concentrado e da proporção de milho e sorgo na dieta, estaria proporcionando maior taxa de degradação.

Para o farelo de soja o efeito ocorreu no sentido inverso, porque o aumento na taxa de diluição, causado pelo aumento no nível de concentrado da dieta e diminuição na relação entre o farelo de soja e algodão : milho e sorgo da dieta 2, diminuiu o tempo de exposição da proteína ao ataque das bactérias proteolíticas, reduzindo, significativamente a sua taxa de degradação da MS.

Os valores obtidos de B (56,06 e 52,39\%), C (23,95 e $26,59 \%)$ e c $(2,96$ e 2,44 $\% / h$ ) da silagem de milho foram próximos aos apresentados por VON KEYSERLINGK \& MATHISON (1989) de $45,1 \%$ para B, $22 \%$ para C e 3,2\%/h para a taxa (c). Valor semelhante, ao deste trabalho, da taxa (c), $2,7 \% / \mathrm{h}$, foi apresentado por SUSMEL et al (1990). Melhor caracterização das silagens utilizadas por esses autores seria necessária para estabelecer-se uma comparação dos valores obtidos.

Para o farelo de soja o valor da taxa (c), obtida neste trabalho, foi inferior ao obtido por HA \& KENNELY (1984), de $5 \% / \mathrm{h}$, por NOCEK (1985), de 9,7\%/h e por CASTILLO ARIAS et al. (1993) de 7,2 \%/h.

\subsubsection{Proteína bruta.}

Não houve efeito de animal sobre as frações solúvel, potencialmente degradável e indegradável, contudo, para a taxa de degradação da fração potencialmente degradável o efeito animal ocorreu $(\mathrm{P}<0,05)$.

As dietas não apresentaram efeito sobre as frações estudadas, exceto para a taxa (c) do farelo de soja $(\mathrm{P}<0,05)$, conforme apresentado na tabela 16.

Para a taxa (c) também foi observado o maior coeficiente de variação entre animais $(23,32 \%)$. Para a fração B o valor do coeficiente de variação foi de $0,45 \%$ e para $C$ de $16,0 \%$. 
Os valores iguais para $\mathrm{A}$, nas duas dietas avaliadas, se devem ao fato de que a lavagem para a determinação da fração protéica solúvel foi feita uma única vez para ambas as dietas, pois o alimento testado nos dois períodos era da mesma origem.

Para a fração B da silagem de milho não houve efeito de dieta, e os valores $36,28 \%$ e $36,32 \%$ mostram que a porção potencialmente degradável nas duas dietas foi praticamente a mesma. $\mathrm{O}$ mesmo foi observado para a fração $\mathrm{C}$.

Tabela 16. Frações solúvel (A), potencialmente degradável (B), indegradável (C) e taxa de degradação da fração potencialmente degradável (c) da proteína bruta da silagem de milho, farelo de soja e sorgo grão, nas dietas avaliadas*.

\begin{tabular}{|c|c|c|c|c|c|c|c|c|}
\hline \multirow{2}{*}{ Alimentos } & \multicolumn{2}{|c|}{ A (\%) } & \multicolumn{2}{|c|}{ B $(\%)$} & \multicolumn{2}{|c|}{ C (\%) } & \multicolumn{2}{|c|}{ c $(\% / h)$} \\
\hline & D1 & D2 & D1 & D2 & $\mathrm{D} 1$ & $\mathrm{D} 2$ & D1 & D2 \\
\hline Sil. de milho & 62,61 & 62,61 & 36,28 & 36,32 & 1,10 & 1,07 & 3,32 & 3,77 \\
\hline F. de soja & 40,53 & 40,53 & 59,28 & 59,92 & 0,18 & 0,55 & $12,32^{\mathrm{a}}$ & $7,62^{b}$ \\
\hline Sorgo grão & 23,91 & 23,91 & 73,12 & 72,64 & 2,97 & 3,46 & 2,56 & 3,24 \\
\hline
\end{tabular}

D1: Dieta com $80 \%$ de volumoso e $20 \%$ de concentrado.

D2: Dieta com $60 \%$ de volumoso e $40 \%$ de concentrado.

"Os valores das frações foram calculados sem levar em consideração o tempo de colonização ("lag time"). Valores seguidos de letras distintas, nas linhas, para uma mesma fração, diferem entre si ao nível de $\mathrm{P}<0,05$.

O aumento do nível de concentrado para $40 \%$ resultou numa diminuição significativa $(\mathrm{P}<0,05)$ da taxa de degradação (c) do farelo de soja de 12,32 para 7,62 \%/h. Para o sorgo grão o aumento na taxa de degradação em 26,6 \% (passando de 2,56 $\% / \mathrm{h}$ para $3,24 \% / \mathrm{h})$ não foi significativo $(P>0,05)$. A silagem de milho apresentou valores semelhantes $(3,32$ e $3,77 \% / h)$ nas duas dietas.

A redução na taxa de degradação da PB do farelo de soja foi mais pronunciada que para a MS ( $38,1 \%$ vs. $18,1 \%$ ), sendo que para o sorgo grão o aumento na taxa de degradação da proteína e da matéria seca ocorreu em proporções semelhantes $(26,6 \%$ vs. $28,4 \%)$. 
Aumento no nível de concentrado pode reduzir a taxa de degradação da proteína e de sua fração potencialmente degradável no rúmen (WEAKLEY et al. , 1983, BÜRGER et al. , 1990 e PETIT, 1994). Porém nenhum efeito ocorreu para a silagem de milho e o sorgo grão.

$O$ aumento no nível de concentrado e na proporção de milho e sorgo na dieta 2 deveria estar proporcionando maior taxa de degradação, porque a degradação mais rápida de outras frações, como o amido, estaria expondo a proteína em menor tempo a ação das bactérias proteolíticas e aumentando sua taxa de degradação.

Para o farelo de soja isto ocorreu no sentido inverso porque o aumento na taxa de diluição, causado pelo aumento no nível de concentrado da dieta, diminuiu o tempo de exposição da proteína ao ataque das bactérias proteolíticas, reduzindo, significativamente a taxa de degradação da proteína, uma vez que ao contrário do sorgo a maior porção do farelo de soja é proteína.

O CNCPS assume B2 como sendo a proteína potencialmente degradável no rúmen. Como pode ser observado, há grande correspondência entre B2, assumida pelo CNCPS, e B apresentada na tabela 16, para todos os alimentos estudados, em ambas dietas avaliadas. B2 foi 37,3\% para a silagem de milho, 59,6 \% para o farelo de soja e $70 \%$ para o sorgo grão, e B próximo a $36 \%, 59 \%$ e $72 \%$, para a silagem , o farelo de soja e sorgo grão, respectivamente, nas duas dietas avaliadas.

Porém o CNCPS assume as taxas de degradação de B2 de 10, 11 e $6 \% / \mathrm{h}$ para a silagem, farelo de soja e o sorgo grão. As taxas obtidas de B foram inferiores para a silagem $(3,32 \% / \mathrm{h}$ na dieta 1 e $3,77 \% / \mathrm{h}$ na dieta 2$)$ e sorgo grão $(2,56 \% / \mathrm{h}$ na dieta 1 e $3,24 \% / h$ na dieta 2 ). Somente para o farelo de soja na dieta 1 o valor foi próximo ao assumido pelo CNCPS $(12,32 \% / h)$, mas na dieta 2 o valor obtido foi inferior $(7,62$ $\% / h)$.

A taxa de degradação da proteína bruta (c) do sorgo grão na dieta $2(2,56 \% / \mathrm{h})$ foi próxima a encontrada por ERASMUS et al. (1990a) para sorgo com alto tanino $(2,5 \% / \mathrm{h})$, mas superior ao valor apresentado por VALADARES FILHO (1994), de $1,49 \% / \mathrm{h}$. 
Utilizando-se $60 \%$ de concentrado HA \& KENNELY (1984) obtiveram para a taxa de degradação da proteína (c), do farelo de soja, $3,6 \% / \mathrm{h}$, inferior aos valores obtidos neste estudo.

\subsubsection{Nitrogênio insolúvel em detergente neutro.}

O NIDN foi avaliado somente para a silagem de milho e farelo de soja.

Os valores das frações solúvel, potencialmente degradável, indegradável e taxa de degradação da fração potencialmente degradável do nitrogênio insolúvel em detergente neutro da silagem de milho e farelo de soja, nas dietas avaliadas, são apresentados na tabela 17.

Tabela 17. Frações solúvel (A), potencialmente degradável (B), indegradável (C) e taxa de degradação da fração potencialmente degradável (c) do nitrogênio insolúvel em detergente neutro da silagem de milho e farelo de soja, nas dietas avaliadas*.

\begin{tabular}{|c|c|c|c|c|c|c|c|c|}
\hline \multirow{2}{*}{ Alimentos } & \multicolumn{2}{|c|}{ A (\%) } & \multicolumn{2}{|c|}{ B (\%) } & \multicolumn{2}{|c|}{ C (\%) } & \multicolumn{2}{|c|}{ c $(\% / h)$} \\
\hline & D1 & D2 & D1 & D2 & D1 & D2 & $\mathrm{D} 1$ & D2 \\
\hline Sil. de milho & 22,41 & 22,41 & 76,98 & 76,94 & 0,61 & 0,65 & $2,71^{\mathrm{a}}$ & $1,84^{b}$ \\
\hline F. de soja & 0,00 & 0,00 & 99,47 & 98,63 & 0,53 & 1,37 & $8,03^{\mathrm{a}}$ & $4,34^{b}$ \\
\hline
\end{tabular}

D1: Dieta com $80 \%$ de volumoso e $20 \%$ de concentrado.

D2: Dieta com $60 \%$ de volumoso e $40 \%$ de concentrado.

" Os valores das fraçð̃es foram calculados sem levar em consideração o tempo de colonização ("lag time"). Valores seguidos de letras distintas, nas linhas, para uma mesma fração, diferem entre si ao nível de $\mathrm{P}<0,15$.

Não houve efeito animal para as diferentes frações estudadas, porém o coeficiente de variação para a taxa de degradação (c) foi elevado (41\%). 
Por se tratar de determinações únicas não há diferenças entre as duas dietas utilizadas, em relação a $\mathrm{A}$. Chama a atenção o caso da fração $\mathrm{A}$ do farelo de soja ser igual a zero. Como parte do FDN do farelo se solubilizou (tabela 18), era de se esperar que parte do NIDN solubilizasse juntamente com o FDN, havendo, portanto, um valor de A superior a zero.

A dieta não apresentou efeito sobre a fração $B$ e $C$, mas houve efeito quanto à taxa (c) ao nível de $\mathrm{P}<0,15$.

O aumento no nível de concentrado reduziu a taxa de degradação (c) do NIDN da silagem de milho e do farelo de soja $(P<0,05)$.

A fração potencialmente degradável (B) do NIDN não foi afetada pela dieta, mas a sua taxa de degradação foi reduzida em $32,1 \%$ para a silagem de milho e em $46 \%$ para o farelo de soja com o aumento do nível de concentrado.

O aumento no nível de concentrado ocasiona redução na degradação da fibra (HOOVER, 1986) e, consequentemente, reduz a taxa de degradação do NIDN.

Considerando-se as divisões propostas pelo CNCPS para a fração protéica, a fração NIDN deste estudo corresponde à fração B3. Para o CNCPS, B3 é de disponibilidade lenta, pois está associada à parede celular, e grande parte não é degradada no rúmen.

A taxa de degradação assumida pelo CNCPS para B3 é de $0,2 \% / \mathrm{h}$ para a silagem com $35 \%$ de grãos e farelo de soja com $49 \%$ de PB. Para a fração carboidrato B2, que corresponde a FDN disponível à degradação ruminal, a taxa de degradação é de $4 \%$ para a silagem de milho, e de $6 \% / \mathrm{h}$ para o farelo de soja. Ocorre certa incoerência entre os valores. Uma vez que estando FDN sendo degradada, era de se esperar que NIDN sofresse a ação de degradação a uma taxa muito semelhante ou ligeiramente inferior a da FDN. Pelos valores assumidos pelo CNCPS a taxa de degradação do NIDN é muito inferior. 
Neste trabalho as taxas (c) obtidas de NIDN (tabela 17) são muito superiores aos valores assumidos pelo CNCPS para os alimentos avaliados (tabela 3 ).

Para a silagem a taxa (c) obtida de NIDN é próxima à taxa (c) da FDN nas duas dietas. Na dieta 1 , a taxa (c) do NIDN foi igual a $2,71 \% / h$, e para a FDN igual a $2,94 \% / \mathrm{h}$. Na dieta 2 esta correspondência se manteve em $1,84 \% / \mathrm{h}$ e $1,5 \% / \mathrm{h}$ para a taxa (c) do NIDN e da FDN, respectivamente.

O mesmo ocorreu para o farelo de soja, sendo na dieta 1 (c) igual a $8,03 \% / \mathrm{h}$ para o NIDN e a $11,33 \% / \mathrm{h}$ para a FDN, e na dieta 2 igual a $4,34 \% / \mathrm{h}$ para o NIDN e a $8,42 \% / h$ para a FDN.

\subsubsection{Fibra em detergente neutro.}

O estudo da FDN foi feito somente para a silagem de milho e farelo de soja, como para o NIDN.

Não houve efeito animal para as frações A, B, C e c. O coeficiente de variação da fração (c) foi elevado $(35,41 \%)$.

Como nos demais componentes estudados, não houve diferença da fração $\mathrm{A}$ em ambas as dietas (tabela 18) por se tratar de uma única determinação da porção solúvel.

Não houve efeito de dietas nas frações $A, B, C$ e $c(P>0,05)$, porém foi observada uma redução na taxa (c) da FDN de $49 \%$ para a silagem de milho e $25,7 \%$ para o farelo de soja.

Os valores de B e (c) $(63,51 \%$ e $2,94 \% / h$ na dieta 1$)$ são semelhantes aos obtidos por VON KEYSERLINGK \& MATHISON (1989) $71,8 \%$ e $2,8 \%$ h para silagem, porém para os autores a fração A foi igual a zero e neste trabalho $16,01 \%$. 
Tabela 18. Frações solúvel (A), potencialmente degradável (B), indegradável (C) e taxa de degradação da fração potencialmente degradável (c) da fibra em detergente neutro da silagem de milho e farelo de soja, nas dietas avaliadas*.

\begin{tabular}{|c|c|c|c|c|c|c|c|c|}
\hline \multirow{2}{*}{ Alimentos } & \multicolumn{2}{|c|}{$A(\%)$} & \multicolumn{2}{|c|}{ B (\%) } & \multicolumn{2}{|c|}{$\mathrm{C}(\%)$} & \multicolumn{2}{|c|}{ c $(\% / \mathrm{h})$} \\
\hline & D1 & D2 & D1 & D2 & D1 & D2 & $\mathrm{D} 1$ & D2 \\
\hline Sil. de milho & 16,01 & 16,01 & 63,51 & 60,43 & 20,48 & 23,56 & 2,94 & 1,50 \\
\hline F. de soja & 26,88 & 26,88 & 68,05 & 66,47 & 5,08 & 6,65 & 11,33 & 8,42 \\
\hline
\end{tabular}

D1: Dieta com $80 \%$ de volumoso e $20 \%$ de concentrado.

D2: Dieta com $60 \%$ de volumoso e $40 \%$ de concentrado.

" Os valores das frações foram cal culados sem levar em consideração o tempo de colonização ("lag time").

Os valores apresentados por SUSMEL et al. (1990) de 65\% para a fração B e $2,4 \% / \mathrm{h}$ para (c) da FDN da silagem de milho também foram próximos aos obtidos neste trabalho. MADSEN et al. (1994) para B da FDN da silagem de milho obtiveram 64,6\%.

Porém, no estudo realizado por VARGA \& HOOVER (1983) a taxa (c) da FDN foi diferente tanto para a silagem de milho como para o farelo de soja: $8,2 \% / \mathrm{h}$ e $5,48 \% / \mathrm{h}$ para a silagem e farelo de soja, respectivamente.

Para fração carboidrato, o CNCPS assume que B2 corresponde à FDN disponível para a degradação ruminal, e apresenta taxa de degradação de $4 \% / \mathrm{h}$ para a silagem de milho com $35 \%$ de grãos e de $6 \% / \mathrm{h}$ para o farelo de soja com $49 \%$ de PB. Neste estudo os valores da taxa de degradação (c) da fração B foram inferiores aos assumidos pelo CNCPS para a silagem de milho $(2,94$ e $1,5 \% / \mathrm{h})$ e superiores para $\mathrm{o}$ farelo de soja $(11,33$ e $8,42 \% / h)$, nas duas dietas avaliadas.

Sendo a silagem de difícil comparação com os dados da literatura por se apresentar muito variável devido a inúmeros fatores que influenciam sobre sua composição, torna-se necessário maior número de dados para confimar ou não os valores obtidos neste estudo. 


\subsubsection{Amido.}

Para o farelo de soja não foi possível determinar a taxa (c) do AM devido ao pequeno número de intervalos que o ensaio de degradação proporcionou para a fração potencialmente degradável, pois o potencial máximo de degradação foi atingido entre 6 e 12 horas.

Mesmo para os demais alimentos, seria necessário maior número de intervalos. Sugere-se que em estudos posteriores, em que se pretende estudar a cinética de digestão do amido, se faça maior número de intervalos entre 2 e 24 horas, visando aumentar o número de pontos que irão descrever a taxa de degradação do amido.

Os valores de A, B e C para a silagem de milho, o farelo de soja e o sorgo grão e da taxa (c) para a silagem de milho e sorgo grão estão expressos na tabela 19.

Tabela 19. Frações solúvel (A), potencialmente degradável (B), indegradável (C) e taxa de degradação da fração potencialmente degradável (c) do amido da silagem de milho, farelo de soja e sorgo grão, nas dietas avaliadas*.

\begin{tabular}{|c|c|c|c|c|c|c|c|c|}
\hline \multirow{2}{*}{ Alimentos } & \multicolumn{2}{|c|}{ A (\%) } & \multicolumn{2}{|c|}{ B (\%) } & \multicolumn{2}{|c|}{$\mathrm{C}(\%)$} & \multicolumn{2}{|c|}{ c $(\% / h)$} \\
\hline & D1 & D2 & D1 & D2 & D1 & D2 & D1 & D2 \\
\hline Sil. de milho & 59,61 & 59,61 & 39,58 & 39,49 & 0,82 & 0,91 & 12,79 & 15,98 \\
\hline F. de soja & 79,33 & 79,33 & 20,31 & 20,56 & 0,36 & 0,12 & $\#$ & $\#$ \\
\hline Sorgo grão & 12,09 & 12,09 & $73,57^{\natural}$ & $70,03^{b}$ & $13,34^{\mathrm{a}}$ & $17,89^{b}$ & $2,91^{\mathrm{a}}$ & $4,08^{b}$ \\
\hline
\end{tabular}

D1: Dieta com $80 \%$ de volumoso e $20 \%$ de concentrado.

D2: Dieta com $60 \%$ de volumoso e $40 \%$ de concentrado.

"Os valores das frações foram calculados sem levar em consideração o tempo de colonização ("lag time"). \# Valores não calculados.

Valores seguidos de letras distintas, nas linhas, para uma mesma fração, diferem entre si ao nível de $\mathrm{P}<0,05$.

Não houve efeito de animal para as diferentes frações estudadas. $O$ coeficiente de variação da taxa (c) foi igual a $21,4 \%$ e da fração C $22,3 \%$ 
Para o farelo de soja não houve efeito das dietas sobre as frações A, B e C. Devido ao pequeno conteúdo de amido do farelo de soja (2,82\% da MS), o seu potencial máximo de degradação foi atingido muito rapidamente (entre 6 e 12 horas), tornando-se difícil detectar efeitos de dieta .

As frações $\mathrm{B}$ e $\mathrm{C}$ e a taxa (c) da silagem de milho não foram afetadas pelo aumento do nível de concentrado na dieta, porém, foi observado aumento da ordem de $24,9 \%$ para a taxa de degradação (c) quando o nível de concentrado passou de 20 para $40 \%$.

A dieta apresentou efeito significativo $(P<0,05)$ sobre as frações $B$ e $C$, e a taxa (c) do AM do sorgo grão.

Para a fração B do sorgo grão o efeito foi negativo, isto é, houve uma redução na porção potencialmente degradável do amido, com o aumento do nível de concentrado em função de um aumento na porção indegradável $\mathrm{C}$.

A taxa (c) do sorgo grão aumentou em $40,2 \%$ na dieta 2 , enquanto que a fração B foi reduzida em somente 4,8 \%. Apesar da fração B manter-se praticamente a mesma, a taxa de degradação aumentou substancialmente com a elevação do nível de concentrado.

Para a silagem o aumento no nível de concentrado reduziu a degradação da fibra e dos componentes protéicos, mas, a degradação do amido foi aumentada. Para o sorgo a maior degradação do amido estaria favorecendo a exposição das demais frações à degradação microbiana, ocasionando aumento da taxa (c) nas demais frações estudadas.

$\mathrm{O}$ AM corresponde à fração $\mathrm{B} 1$ do $\mathrm{CNCPS}$. $\mathrm{O}$ modelo assume para $\mathrm{B} 1$ da silagem de milho com $35 \%$ de grãos uma taxa de degradação de $30 \% / \mathrm{h}$ e de $12 \% / \mathrm{h}$ para o sorgo grão.

Analogamente ao que ocorreu com o teor de AM, os valores obtidos neste experimento para as taxas de degradação (c), 12,79 e 15\%/h para a silagem e 2,91 e $4,08 \% / h$ para o sorgo grão, para as dietas 1 e 2 respectivamente, são inferiores aos assumidos pelo modelo ( $30 \% / \mathrm{h}$ para a silagem de milho e $12 \% / \mathrm{h}$ para o sorgo grão). 
Estudos que avaliaram a cinética de digestão do amido são raros. WANDERLEY et al. (1992) obtiveram valores próximos ao deste trabalho para a fração potencialmente degradável e a taxa de degradação do amido do sorgo extrusado e esmagado, em dieta com $50 \%$ de volumoso e $50 \%$ de concentrado. Os autores obtiveram valores de $80,4 \%$ e 77,0 \% para a fração potencialmente degradável (B), e de 4,1 \%/h e $3,5 \% / h$ para taxa de degradação (c) do grão de sorgo extrusado e esmagado, respectivamente.

\subsection{Degradabilidade potencial e efetiva dos componentes avaliados.}

\subsubsection{Degradabilidade potencial e efetiva da matéria seca.}

Não houve efeito de animal sobre a degradabilidade potencial e efetiva da matéria seca (DPMS e DEMS) das dietas avaliadas, considerando-se ou não o "lag time" nos cálculos.

Os valores das DPMS e DEMS, com e sem "lag time", de silagem de milho, farelo de soja e sorgo grão, nas dietas avaliadas, são apresentados na tabela 20.

A dieta não afetou a DPMS dos alimentos estudados.

Não houve efeito de dieta $(P>0,05)$ sobre a DEMS, quando não se considerou o "lag time". Quando se considerou o "lag time", o efeito da dieta ocorreu somente para a DEMS da silagem de milho. Houve aumento significativo $(P<0,05)$ da DEMS da silagem de milho com o aumento do nível de concentrado da dieta, sendo este aumento da ordem de $19,7 \%$. Vale salientar que o "lag time" observado para a silagem de milho na dieta 2 foi de 6,4 horas enquanto que na dieta 1 foi de 2,1 horas. 
Tabela 20. Degradabilidade potencial e efetiva", com e sem "lag time", da matéria seca da silagem de milho, farelo de soja e sorgo grão, nas dietas avaliadas.

\begin{tabular}{|c|c|c|c|c|c|c|c|c|}
\hline \multirow{3}{*}{ Alimentos } & \multicolumn{4}{|c|}{ Degradabilidade Potencial (\%) } & \multicolumn{4}{|c|}{ Degradabilidade Efetiva (\%) } \\
\hline & \multicolumn{2}{|c|}{$\begin{array}{l}\text { Sem } \\
\text { "lag time" }\end{array}$} & \multicolumn{2}{|c|}{$\begin{array}{c}\text { Com } \\
\text { "lag time" }\end{array}$} & \multicolumn{2}{|c|}{$\begin{array}{l}\text { Sem } \\
\text { "lag time" }\end{array}$} & \multicolumn{2}{|c|}{$\begin{array}{c}\text { Com } \\
\text { "lag time" }\end{array}$} \\
\hline & D1 & D2 & D1 & D2 & D1 & D2 & D1 & D2 \\
\hline S. de milho & 69,13 & 66,24 & 71,25 & 70,92 & $45,10^{\mathrm{a}}$ & $43,35^{\mathrm{a}}$ & $55,66^{b}$ & $66.62^{\mathrm{c}}$ \\
\hline F. de soja & 98,41 & 95,00 & 98,43 & 96,94 & $81,09^{a}$ & $77,38^{\mathrm{a}}$ & $91,18^{b}$ & $89.50^{b}$ \\
\hline Sorgo grão & 64,82 & 63,07 & 69,61 & 66,82 & $46,23^{\mathrm{a}}$ & $47,33^{\mathrm{a}}$ & $57,26^{b}$ & $56,96^{b}$ \\
\hline
\end{tabular}

D1: Dieta com $80 \%$ de volumoso e $20 \%$ de concentrado.

D2: Dieta com $60 \%$ de volumoso e $40 \%$ de concentrado.

* Degradabilidade efetiva calculada a partir da taxa de passagem estimada por amostras de fezes. Valores seguidos de letras distintas, nas linhas, para um mesmo parâmetro avaliado (degradabilidade potencial ou efetiva), diferem entre si ao nivel de $P<0,05$.

Considerando-se o "lag time", a fração A passa a ser a porção solúvel até que o processo de degradação se inicie. $\mathrm{O}$ valor de A sofre aumento, porque a porção solúvel no líquido ruminal é mais elevada que somente em água. A fração B diminui, por haver aumento de A, para um mesmo valor de C. A taxa (c) diminuiu.

Os cálculos que levam em consideração o "lag time" se opõem aos resultados encontrados para as frações A, B, C e taxa (c) da matéria seca nos alimentos estudados.

Os valores de DEMS considerando-se o "lag time" deveriam acompanhar o comportamento dos valores obtidos quando não se considerou o "lag time", havendo somente uma elevação significativa destes valores $(P<0,05)$, conforme a tabela 20 .

Os valores obtidos considerando-se o "lag time" devem ser vistos com cautela, uma vez que, além de pouco utilizado, o conceito de "lag time" nunca foi revisto ou reformulado. 
Quando se utiliza o "lag time" e foi executada a lavagem dos sacos antes da introdução no rúmen, foge-se da proposta inicial. A fração solúvel foi definida como sendo aquela que desaparece quando se submetem os sacos em água a $39^{\circ} \mathrm{C}$, com leve agitação por 15 minutos antes da introdução dos sacos no rúmen. Desta forma, a porção solúvel estaria sendo considerada duas vezes.

Os valores sem utilizar o "lag time", além de acompanhar a lógica esperada quanto ao efeito da dieta, são mais coerentes quando comparados com os dados da literatura.

VALADARES FILHO et al. (1991) obtiveram valores próximos a $36 \%$ de degradabilidade da matéria seca da silagem de milho. Em estudo posterior (VALADARES FILHO et al. 1992), o valor obtido foi de $41,4 \%$ de degradabilidade aparente da MS da silagem de milho com 6,4\% de PB e 34,1\% de FDN. Em seu estudo, onde foi feita uma coletânea de diversos trabalhos, VALADARES FILHO (1994) apresentou valores de $33,4 \%$ e $45,1 \%$ de DEMS da silagem de milho, com taxa de passagem da dieta de 2 e $5 \% / \mathrm{h}$ respectivamente. SUSMEL et al. (1990) apresentaram valores superiores, da ordem de $54,0 \%$ para taxas de passagem de $2 \% / \mathrm{h}$.

Para taxa de passagem de $2 \% / h$, VILELA (1994) obteve o valor de $81,6 \%$ para a DEMS do farelo de soja. Valor próximo a este $(76,7)$ foi obtido por VALADARES FILHO et al. (1991) com taxa de passagem da dieta de $3 \% / \mathrm{h}$. O valor de $82,0 \%$ foi apresentado por VALADARES FILHO et al. (1994) em dieta com taxa de passagem de $2 \% / \mathrm{h}$.

Para o sorgo grão, o valor obtido para a DEMS, sem considerar o "lag time", nas dietas 1 e $2(46,23 \%$ e 47,33\%) foram próximos a 49,2\% obtido por VALADARES FILHO et al. (1991) para o sorgo grão, com taxa de passagem da dieta de $3 \% / \mathrm{h}$. Os valores também encontram-se entre $37,4 \%$ e $59,2 \%$ apresentados por VALADARES FILHO (1994) para o sorgo grão com taxas de passagem da dieta de 2 e $5 \% / h$ respectivamente.

Valores de DEMS dos alimentos estudados, com as taxas de passagem de 2, 5 e $8 \% / \mathrm{h}$ são apresentados na tabela 30 do apêndice. 


\subsubsection{Degradabilidade potencial e efetiva da proteína bruta.}

Os valores obtidos para a degradabilidade potencial e efetiva da proteína bruta (DPPB e DEPB), com e sem "lag time", da silagem de milho, farelo de soja e sorgo grão, nas dietas avaliadas, estão expressos na tabela 21.

Não houve efeito de animal sobre nenhum dos parâmetros avaliados. Não houve também efeito da dieta $(P>0,05)$ sobre a DPPB e a DEPB, considerando-se ou não o "lag time" .

Ao contrário do que ocorreu para a DEMS, a DEPB se comportou de de maneira igual considerando-se ou não o "lag time".

Tabela 21. Degradabilidade potencial e efetiva", com e sem "lag time", da proteína bruta da silagem de milho, farelo de soja e sorgo grão, nas dietas avaliadas.

\begin{tabular}{|c|c|c|c|c|c|c|c|c|}
\hline \multirow{3}{*}{ Alimentos } & \multicolumn{4}{|c|}{ Degradabilidade Potencial (\%) } & \multicolumn{4}{|c|}{ Degradabilidade Efetiva (\%) } \\
\hline & \multicolumn{2}{|c|}{$\begin{array}{l}\text { Sem } \\
\text { "lag time" }\end{array}$} & \multicolumn{2}{|c|}{$\begin{array}{l}\text { Com } \\
\text { "lag time" }\end{array}$} & \multicolumn{2}{|c|}{$\begin{array}{l}\text { Sem } \\
\text { "lag time" }\end{array}$} & \multicolumn{2}{|c|}{$\begin{array}{l}\text { Com } \\
\text { "lag time" }\end{array}$} \\
\hline & D1 & D2 & D1 & D2 & D1 & D2 & Dl & D2 \\
\hline S. de milho & 95,45 & 96,31 & 95,31 & 96,20 & 79,93 & 81,83 & 83,00 & 85,22 \\
\hline F. de soja & 98,82 & 96,93 & 99,66 & 97,05 & 86,06 & 80,05 & 93,05 & 86,20 \\
\hline Sorgo grão & 75,05 & 80,90 & 76,03 & 81,74 & 54,09 & 59,71 & 56,19 & 62,48 \\
\hline
\end{tabular}

D1: Dieta com $80 \%$ de volumoso e $20 \%$ de concentrado.

D2: Dieta com $60 \%$ de volumoso e $40 \%$ de concentrado.

* Degradabilidade efetiva calculada a partir da taxa de passagem estimada por amostras de fezes. Valores seguidos de letras distintas, nas linhas, para um mesmo parâmetro avaliado (degradabilidade potencial ou efetiva), diferem entre si ao nivel de $\mathrm{P}<0,05$.

Os valores de DEPB da silagem de milho, obtidos neste trabalho, acima de $79,0 \%$ nas duas dietas avaliadas, são superiores aos apresentados por SUSMEL et al. (1990), de $69,0 \%$ para silagem de teor protéico semelhante (7,13\% de PB neste trabalho e 7,8\% de PB no trabalho de SUSMEL et al.). 
ERASMUS et al. (1990b) também apresentaram valores de DEPB para a silagem de milho próximos aos obtidos neste estudo, $83,0 \%$ a $79,5 \%$, com taxas de passagem das dietas de 2 a $8 \%$. O valor de 52,0\%, obtido por VALADARES FILHO et al. (1992), foi inferior a todos.

ERASMUS E PRINSLOO (1988) obtiveram o valor de 79,5\% para a DEPB do farelo de soja, quando a taxa de passagem da dieta foi de $2 \% / \mathrm{h}$, valor próximo ao obtido neste trabalho para a dieta 2, sem se considerar o "lag time" (80,05\%). CASTILLO ARIAS et al. (1993) obtiveram o valor de 80,5 para a DEPB do farelo de soja, com taxa de passagem da dieta de $2 \%$ e VILELA (1994) o valor de $81,6 \%$ para taxa de passagem da dieta de $2 \% / \mathrm{h}$.

Para o sorgo grão, os valores obtidos de $54,09 \%$ e $59,71 \%$ para as dietas 1 e 2 , com taxas de passagem de 5 e $2 \% / h$, sem ser considerado o "lag time", se aproximaram dos apresentados por ERASMUS et al. (1990a) para o sorgo com alto tanino, de $52 \%$ e $69 \%$ para taxas de passagem da dieta de 5 e $2 \% / h$.

Os valores de DEPB sob diferentes taxas de passagem encontram-se no apêndice ( tabela 31). Os valores obtidos utilizando-se taxas de passagem de 2,5 e $8 \%$ são superiores aos apresentados pelos diversos autores para os alimentos avaliados.

\subsubsection{Degradabilidade potencial e efetiva do nitrogênio insolúvel em detergente neutro}

A degradabilidade potencial e efetiva, com e sem "lag time", do NIDN da silagem de milho e do farelo de soja, nas dietas avaliadas, encontram-se na tabela 22.

Houve efeito de animal $(P<0,05)$ para a degradabilidade efetiva do nitrogênio insolúvel em detergente neutro (DENIDN). Para a degradabilidade potencial do nitrogênio insolúvel em detergente neutro (DPNIDN) este efeito não ocorreu.

A DPNIDN não foi afetada pelo aumento do nível de concentrado na dieta. 
Tabela 22. Degradabilidade potencial e efetiva*, com e sem "lag time", do nitrogênio insolúvel em detergente neutro da silagem de milho e farelo de soja, nas dietas avaliadas.

\begin{tabular}{|c|c|c|c|c|c|c|c|c|}
\hline \multirow{3}{*}{ Alimentos } & \multicolumn{4}{|c|}{ Degradabilidade Potencial (\%) } & \multicolumn{4}{|c|}{ Degradabilidade Efetiva (\%) } \\
\hline & \multicolumn{2}{|c|}{$\begin{array}{l}\text { Sem } \\
\text { "lag time" }\end{array}$} & \multicolumn{2}{|c|}{$\begin{array}{c}\text { Com } \\
\text { "lag time" }\end{array}$} & \multicolumn{2}{|c|}{$\begin{array}{l}\text { Sem } \\
\text { "lag time" }\end{array}$} & \multicolumn{2}{|c|}{$\begin{array}{c}\text { Com } \\
\text { "lag time" }\end{array}$} \\
\hline & D1 & D2 & D1 & D2 & Dl & D2 & D1 & $\mathrm{D} 2$ \\
\hline S. de milho & 86,74 & 77,83 & 89,96 & 83,52 & 54,79 & 49,56 & 58,58 & 54,46 \\
\hline F. de soja & 96,54 & 80,87 & 97,93 & 90,46 & 67,75 & 51,08 & 71,06 & 61,23 \\
\hline
\end{tabular}

D1: Dieta com $80 \%$ de volumoso e $20 \%$ de concentrado.

D2: Dieta com $60 \%$ de volumoso e $40 \%$ de concentrado.

* Degradabilidade efetiva calculada a partir da taxa de passagem estimada por amostras de fezes.

Valores seguidos de letras distintas, nas linhas, para um mesmo parâmetro avaliado (degradabilidade potencial ou efetiva), diferem entre si ao nível de $\mathrm{P}<0,05$.

A DENIDN também não foi afetada pelo aumento do nível de concentrado da dieta.

O uso do "lag time", ao contrário do ocorrido com as degradabilidades efetivas dos demais componentes avaliados, não afetou significativamente a DENIDN, apesar de apresentar valores mais elevados do que quando este não foi considerado.

Os valores de DENIDN acompanharam a tendência apresentada pela taxa de degradação (c) do NIDN (tabela 17). O aumento no nível de concentrado da dieta prejudicou a degradabilidade da maioria dos componentes avaliados da silagem de milho e farelo de soja.

Conforme demonstrado a seguir, a redução na DENIDN acompanhou a tendência observada para a degradabilidade efetiva da fibra em detergente neutro, quando o "lag time" não foi considerado.

Os valores de DENIDN com as taxas de passagem da dieta de 2,5 e $8 \% / \mathrm{h}$ nas dietas utilizadas neste experimento são apresentados no apêndice, na tabela 33. 


\subsubsection{Degradabilidade potencial e efetiva da fibra em detergente neutro.}

Não houve efeito de animal sobre a degradabilidade potencial da fibra em detergente neutro (DPFDN), porém, para a degradabilidade efetiva (DEFDN) este efeito foi observado $(P<0,05)$.

Tabela 23. Degradabilidade potencial e efetiva*, com e sem "lag time", da fibra em detergente neutro da silagem de milho e farelo de soja, nas dietas avaliadas.

\begin{tabular}{|c|c|c|c|c|c|c|c|c|}
\hline \multirow{3}{*}{ Alimento } & \multicolumn{4}{|c|}{ Degradabilidade Potencia (\%) } & \multicolumn{4}{|c|}{ Degradabilidade Efetiva (\%) } \\
\hline & \multicolumn{2}{|c|}{$\begin{array}{c}\text { Sem } \\
\text { "lag time" }\end{array}$} & \multicolumn{2}{|c|}{$\begin{array}{l}\text { Com } \\
\text { "lag time" }\end{array}$} & \multicolumn{2}{|c|}{$\begin{array}{l}\text { Sem } \\
\text { "lag time" }\end{array}$} & \multicolumn{2}{|c|}{$\begin{array}{c}\text { Com } \\
\text { "lag time" }\end{array}$} \\
\hline & D1 & D2 & $\mathrm{D} 1$ & D2 & $\mathrm{D} 1$ & D2 & $\mathrm{D} 1$ & D2 \\
\hline S. de milho & $70,39^{\mathrm{a}}$ & $54,37^{b}$ & $71,53^{\mathrm{a}}$ & $54,32^{b}$ & $43,95^{\mathrm{a}}$ & $34,35^{b}$ & $48,56^{\mathrm{a}}$ & $40,14^{b}$ \\
\hline F. de soja & $94,42^{\mathrm{a}}$ & $90,46^{\mathrm{a}}$ & $94,61^{\mathrm{a}}$ & $98,78^{\mathrm{a}}$ & $77,90^{\mathrm{a}}$ & $72,50^{\mathrm{a}}$ & $79,92^{\mathrm{a}}$ & $85,71^{b}$ \\
\hline
\end{tabular}

D1: Dieta com $80 \%$ de volumoso e $20 \%$ de concentrado.

D2: Dieta com $60 \%$ de volumoso e $40 \%$ de concentrado.

* Degradabilidade efetiva calculada a partir da taxa de passagem estimada por amostras de fezes. Valores seguidos de letras distintas, nas linhas, para um mesmo parâmetro avaliado (degradabilidade potencial ou efetiva), diferem entre si ao nível de $\mathrm{P}<0,05$.

Houve efeito significativo $(P<0,05)$ da dieta sobre a DPFDN da silagem de milho (tabela 23). Com o aumento do nível de concentrado houve redução em torno de 24 \% da DPFDN, considerando-se ou não o "lag time". O uso do "lag time" não afetou o valor da DPFDN da silagem de milho.

A DPFDN do farelo de soja não foi afetada com o aumento do nível de concentrado na dieta.

Porém, o uso do "lag time" proporcionou uma inversão na tendência da DPFDN: não sendo considerando, a DPFDN do farelo de soja diminuiu, e quando considerado, a DPFDN aumentou significativamente. 
Houve efeito significativo $(\mathrm{P}<0,05)$ da dieta sobre a DEFDN da silagem de milho, quando o "lag time" foi ou não considerado. Seguindo o que foi observado para a taxa de degradação (c) da FDN, o aumento no nível de concentrado da dieta proporcionou redução de 21,8 \% da DEFDN, quando o "lag time" não foi considerado. O uso do "lag time" proporcionou DEFDN da silagem mais elevada, porém, o efeito da dieta foi menos pronunciado. $O$ aumento do nível de concentrado, aumentado a taxa de diluição e reduzindo a atividade celulolítica no rúmen (HOOVER, 1986, POORE, 1987 e PETIT, 1994), são os fatores que levaram a redução da DEFDN.

Para o farelo de soja quando o "lag time" foi considerado, houve aumento de 7\% ( $P>0,05)$ para a DEFDN. Os valores não acompanham a tendência observada para a taxa (c) da FDN quando não considerou-se o "lag time" (tabela 18) ou quando este foi considerado (tabela 27- apêndice). Em ambos os casos a taxa (c) foi reduzida com o aumento do nível de concentrado, para valores da fração B muito próximos.

A DEFDN da silagem de milho obtida $(43,95 \%$ na dieta 1 e $34,35 \%$ na dieta 2, sem "lag time") foi inferior ao valor apresentado por SUSMEL et al. de 51,0\%.

Os valores de DEFDN dos alimentos estudados, na dietas avaliadas, com as taxas de passagem das dietas de 2,5 e $8 \%$, são apresentadas da tabela 32 do apêndice.

\subsubsection{Degradabilidade potencial e efetiva do amido.}

As degradabilidades potencial e efetiva, com e sem "lag time", do amido da silagem de milho e sorgo grão, nas dietas avaliadas, são apresentadas na tabela 24 .

Houve efeito animal $(\mathbf{P}<0,05)$ para a degradabilidade efetiva do amido (DEAM).

Para a degradabilidade potencial do amido (DPAM) não houve efeito da dieta, considerando-se ou não o "lag time". Os valores obtidos de DPAM com e sem "lag time" foram semelhantes, não evidenciando tendências, para os dois alimentos avaliados. 
Tabela 24. Degradabilidade potencial e efetiva*, com e sem "lag time", do amido da silagem de milho e sorgo grão, nas dietas avaliadas.

\begin{tabular}{|c|c|c|c|c|c|c|c|c|}
\hline \multirow{3}{*}{ Alimento } & \multicolumn{4}{|c|}{ Degradabilidade Potencial (\%) } & \multicolumn{4}{|c|}{ Degradabilidade Efetiva (\%) } \\
\hline & \multicolumn{2}{|c|}{$\begin{array}{c}\text { Sem } \\
\text { "lag time" }\end{array}$} & \multicolumn{2}{|c|}{$\begin{array}{c}\text { Com } \\
\text { "lag time" }\end{array}$} & \multicolumn{2}{|c|}{$\begin{array}{l}\text { Sem } \\
\text { "lag time" }\end{array}$} & \multicolumn{2}{|c|}{$\begin{array}{l}\text { Com } \\
\text { "lag time" }\end{array}$} \\
\hline & D1 & D2 & D1 & D2 & D1 & D2 & D1 & D2 \\
\hline S. de mitho & 99,18 & 99,10 & 99,25 & 96,56 & $90,33^{\mathrm{a}}$ & $92,05^{a}$ & $93,57^{\mathrm{a}}$ & $93,47^{\circ}$ \\
\hline Sorgo grão & 67,94 & 71,76 & 68,69 & 77,76 & $45,20^{\mathrm{a}}$ & $50,57^{\mathrm{a}}$ & $49,90^{\mathrm{a}}$ & $63,15^{b}$ \\
\hline
\end{tabular}

D1: Dieta com $80 \%$ de volumoso e $20 \%$ de concentrado.

D2: Dieta com $60 \%$ de volumoso e $40 \%$ de concentrado.

* Degradabilidade efetiva calculada a partir da taxa de passagem estimada por amostras de fezes. Valores seguidos de letras distintas, nas linhas, para um mesmo parâmetro avaliado (degradabilidade potencial ou efetiva), diferem entre si ao nível de $\mathrm{P}<0,05$.

A silagem de milho não foi afetada pela dieta quanto a DEAM. Os valores obtidos com e sem o "lag time" foram semelhantes.

Houve um aumento significativo $(P<0,05)$ de $26,5 \%$ na DEAM do sorgo grão quando o nível de concentrado da dieta foi elevado de 20 para $40 \%$ e o "lag time" foi considerado para cálculo da DEAM.

Os valores de DEAM foram mais elevados quando o "lag time" foi considerado. 0 "lag time" da dieta 2 foi $50 \%$ superior ao da dieta $1(1,02$ vs. $0,50 \mathrm{~h})$. Desta forma 0 valor da fração A foi muito superior para a dieta 2, levando a um aumento da DEAM na dieta 2 em relação a 1 quando o "lag time" foi considerado.

Como ocorrido para a taxa (c) do amido (tabela 19), o aumento do nível de concentrado na dieta aumentou a DEAM do sorgo grão. $O$ aumento na atividade amilolítica no rúmen, causado pelo aumento do nível de concentrado e proporção de milho e sorgo na dieta, estaria proporcionando maior taxa de degradação. do amido. 


\section{CONCLUSÕES.}

O aumento do nível de concentrado da dieta afetou negativamente a silagem de milho e o farelo de soja e favoreceu o sorgo grão quanto a degradabilidade de algumas frações avaliadas.

Tendo os valores obtidos em relação aos componentes das frações protéicas dos alimentos sido muito variáveis, haveria necessidade de maior número de dados para concluir sobre a correspondência deles ou não com os dados assumidos pelo CNCPS

O valor obtido de amido dos alimentos, foi inferior aos do CNCPS e aos demais da literatura, provavelmente devido à metodologia empregada por estes, que estaria superestimando esta fração. Não tendo sido possível estabelecer uma curva bem determinada relativa à degradação do amido nos tempos iniciais ( 2 e 12 horas), teria que ser introduzido maior número de intervalos nesse período.

Diante da grande variação entre animais, quanto a taxas de passagem, estas devem ser determinadas sempre que possível, tomando-se específica para cada animal e não se empregando um valor médio, como na maioria dos estudos realizados.

As taxas de degradação assumidas pelo CNCPS diferentes das obtidas neste experimento, para algumas frações analisadas, demonstra a necessidade de maior número de dados para ajuste do modelo em nossas condições e para nossos alimentos.

A existência de "lag time" é uma realidade. Entretanto o critério atual para a determinação do seu valor, bem como para a sua utilização no cálculo da degradabilidade potencial e efetiva dos componentes alimentares pode levar a conclusões errôneas, uma vez que seu emprego neste estudo proporcionou até inversão de valores do efeito de dieta em algumas frações. 


\section{REFERÊNCIAS BIBLIOGRÁFICAS}

AGRICULTURAL RESEARCH COUNCIL. The nutrient requeriments of ruminant livestock Supplement 1. Farnham Royal, 1984. 45 p.

ANDRADE, $P$. Técnica "in situ" (sacos de náilon) na avaliação de alimentos para ruminantes. In: SIMPÓSIO INTERNACIONAL DE PRODUÇÃO DE RUMINANTES, REUNIÃO ANUAL DA SOCIEDADE BRASILEIRA DE ZOOTECNIA, 31., Maringá, 1994. Anais. Maringá, SBZ, 1994. p.141-7.

ASSOCIATION OF OFFICIAL ANALYTICAL CHEMISTS. Official methods of analysis of the association of official analytical chemists. 11.ed. Washington, 1970. $1015 \mathrm{p}$.

AUSTRALIAN AGRICULTURAL COUNCIL. Feedings standands for australian livestock Victória,1990. 266p.

BÜRGER, P.J.; SANCHEZ, L.M.B.; PIRES, M.B.G.; ZANNELLA, I. Avaliação da técnica "in situ" para a estimativa da degradação ruminal de proteínas. Pesquisa Agropecuária Brasileira, Brasília, 25(9):1215-21, 1990.

CASTILlO ARIAS, A. M. Avaliação da degradabilidade ruminal e da digestibilidade intestinal de vários alimentos utilizando-se a técnica do saco de náilon móvel. Viçosa, 1992. 103 p. (MS - Universidade Federal de Viçosa).

CASTILLO ARIAS, A.M.; VALADARES FILHO, S.C; SILVA, J.F.C. da; LEÃO, M.I.; CASTRO, A.C.G. Degradabilidade ruminal da matéria seca e da proteína bruta de alimentos, utilizando-se a técnica dos sacos de náilon, em vacas gestantes alimentadas com feno (80\%) e concentrados (20\%). Revista da Sociedade Brasileira de Zootecnia, Viçosa, 22(1):89-98, 1993. 
CHERNEY, D.J.R.; PATTERSON, J.A.; LEMENAGER, R.P. Influence of in situ bag rising technique on determination of dry matter disappearance. Joumal of Dairy Science, Champaign, 73(2):391-7,1990.

COLUCCI, P.E.; CHASE, L.E.; VAN SOEST, P.J. Feed intake, apparent diet digestibility, and rate of particulate passage in dairy cattle. Joumal of Dairy Science, Champaign, 65(8):1445-56, 1982.

CORNELL UNIVERSITY NET CARBOHYDRATE \& PROTEIN SYSTEM. Version 3.0 - Beta test, Ithaca. 1994. (Disquete)

EHLE, F.R. Influence of feed particle density on particulate passage from rumen of holstein cow. Joumal of Dairy Science, Champaign, 67(3):693-7, 1984.

ERASMUS, L.J. \& PRINSLOO J. The establisment of protein degradability data base for cattle using nylon bag technique. 1.Protein sources. South African Joumal of Animal Science, Pretória, 18(1):23-9, 1988.

ERASMUS, L.J.; PRINSLOO, J.; BOTHA, P.M. Establishment of ruminal protein degradation data base for dairy cattle using the "in situ" polyester bag technique. 3. Roughages. South African Joumal of Animal Science, Pretória, 20(3):124-9, 1990a.

ERASMUS, L.J.; PRINSLOO, J.; BOTHA, P.M. Establishment of ruminal protein degradation data base for dairy cattle using the "in situ" polyester bag technique. 3. Roughages. South African Joumal of Animal Science, Pretória, 20(3):130-5, $1990 \mathrm{~b}$.

ERDMAN, R.A.; VANDERSALL, J.H.; RUSSEK-COHEN, E.; SWITALSKI, G. Simultaneous meansures of rates of ruminal digestion and passage of feeds for prediction of ruminal nitrogen and dry matter digestion in lactanting dairy cows. Joumal of Animal Science, Champaign, 64(2):565-77, 1987

EVANS, E. An evaluation of the relationships between dietary parameters and rumen solid turnover rate. Canadian Joumal Animal Science, Ottawa, 61(1):97-103,1981. 
FARIA, V.P. \& HUBER, J.T. Influence of dietary protein and energy on disappearance of dry matter from different forage types from dacron bags suspended in the rumen. Joumal of Animal Science, Champaign, 59(3): 246-51, 1984.

FOX, D.G. \& BARRY, M.C. Predicting cattle net energy and protein requeriments and supply under widely varyng conditions. In: SYMPOSIUM "LIVESTOCK PRODUCTION FOR 21st CENTURY", Regina, 1994.

FOX, D.G.; SNIFFEN, C.J.; O'CONNOR, J.D.; RUSSEL, J.B.; VAN SOEST, P.J. The comell net carbohydrate and protein system for evaluating catle diets. Ithaca, Cornell. 1990. $128 \mathrm{p}$.

GOERING, H.K. \& VAN SOEST, P.J. Forage fiber analysis (apparatus, reagents, procedures, and some aplications). Washington, USDA/ARS., 1970. $379 \mathrm{p}$.

GOETSCH, A.L. \& OWENS, F.N. Effects of sampling site on passage rate estimates in heifers fed alfafa hay or a high concentrate diet. Joumal of Dairy Science, Champaign, 68(4):914-22, 1985.

GROVUM, L.W. \& WILLIAMS, V.J. Rate of passage of digesta. 4. Passage of marker trough the alimentary tract and the biological relevance of rate-constants derived from changes in concentration of marker in faeces. British Joumal of Nutrition, Cambrigde, 30:313-29,1973.

HA, J.K. \& KENNELY, J.J. In situ dry matter and protein degradation of various protein sources in dairy cattle. Canadian Joumal Animal Science, Ottawa, 64(6):443-52, 1984.

HARTNELL, G.F. \& SATTER, L.D. Determination of rumen fill, retention time and ruminal turnover rates of ingesta at different stages of lactation in dairy cows. Joumal of Animal Science, Champaign, 48(2):381-92, 1979.

HIBBERD, C.A.; WAGNER, D.G.; SCHEMM, R.L., MITCHELL Jr., E.D. Nutritive characteristics of different varieties of sorghum an corn grains. Joumal of Animal Science, Champaign, 55(3):665-72, 1982. 
HOOVER, W.H. Chemical factors involved in ruminal fiber digestion. Joumal of Dairy Science, Champaing, 69(10): 2755-66, 1986.

JANICKI, F.J. \& STALLINGNS, C.C. Degradation of crude protein in forages determined by in vitro and in situ procedures. Joumal of Dairy Science, Champaign, 71(9):2440-8, 1988.

KRISHNAMOORTHY, U.; MUSCATO, T.V.; SNIFFEN C.J.; VAN SOEST, P.J. Nitrogen fractions in selected feedstuffs. Joumal of Dairy Science, Champaign, 65(2):217-25, 1982.

MACRAE, J.C. \& ARMSTRONG, D.G. Enzyme method for determination of $\propto$-linked glucose polymers in biological materials. Joumal of the Science of Food and Agriculture, London, 19(10):578-81, 1968.

MADSEN, J.; STENSIG, T.; WEISBJERG, M.R.; HVELPLUND, T. Estimation of the fisical fill of feedstuffs in rúmen by the in sacco degradation characteristics. Livestock Prodution Science, Amsterdam, 39(1):43-7, 1994.

McDONALD, I. A revised model for the estimation of protein degradability in the rumen. Joumal of Agricultural Science, Cambridge, 96(1):251-2, 1981.

MEHREZ, A.Z. \& ORSKOV, E.R. A study of the artificial fiber bag technique for determining the digestibility of feeds in the rumen. Joumal of Agricultural Science, Cambridge, 88:645-50, 1977.

MERTENS, D.R. Kinetics of cell wall digestion and passage in ruminats. In: JUNG, H.G.; BUXTON, D.R.; HATFIELD, R.D.; RALPH, J. Forage cell wall struture and digestibility. Madison, USDA, 1993. cap. 21, p.535-70.

MERTENS, D.R. \& LOFTEN, J.R. The effect of starch on forage fiber digestion kinetics "in vitro". Joumal of Dairy Science, Champaing, 63(9):1437-46, 1980. 
MEYER, J.H.F. \& MACKIE, R.I. Microbiological evaluation of the intraruminal in sacculus digestion techinique. Applied and Environmental Microbiology, Baltimore, 51(3):622-9,1986.

NATIONAL RESEARCH COUNCIL. Ruminant nitrogen usage. Washington, National Academy Press, 1985. 138p.

NATIONAL RESEARCH COUNCIL. Nutrient requeriments of dairy cattle. 6.ed., Washington, National Academy Press, 1989. 157p.

NOCEK, J.E. Evaluation of specific variables affecting in situ estimates of ruminal dry matter and protein digestion. Joumal of Animal Science, Champaign, 60(5): 1347-58, 1985.

NOCEK, J.E. In situ and other methods to estimate ruminal protein and energy digestibility: a review. Joumal of Dairy Science, Champaign, 71(8):2051-69, 1988.

ORSKOV, E.R. \& McDONALD, I. The estimation of protein degradability in the rumen from incubation measurements weighted according to rate of passage. Joumal of Agricultural Science, Cambrigde. 92(2):499-503, 1979.

PATTON, R.S. Complexities of soluble carbohydrate metabolism in ruminants. Feedstuffs, Minneapolis 66(6): 13-9, 1994.

PEREIRA, J.R.A. \& ROSSI Jr., P. Manual prático de avaliação nutricional de alimentos. Piracicaba, FEALQ, 1994.25 p. (no prelo)

PETIT, H.V.; RIOUX, R.; TREMBLAY, G. F. Evaluation of forages and concentrates by the "in situ" degradability technique. In:SIMPÓSIO INTERNACIONAL DE PRODUÇÃO DE RUMINANTES, REUNIÃO ANUAL DA SOCIEDADE BRASILEIRA DE ZOOTECNIA, 31., Maringá, 1994. Anais. Maringá, SBZ, 1994 p.119-33. 
PIAGGIO, L.M.; PRATES, E.R.; PIRES, F.F.; OSPINA, H. Avaliação do cromo mordente como indicador externo da produção fecal. Revista da Sociedade Brasileira de Zootecnia, Viçosa, 20(3):313-8, 1991.

POORE, M.H. Rumen passage rates and fiber digestibilities for wheat straw, alfafa hay and flaked sorghum grain in mixed diets for steers. Arizona, 1987. 77p. (MSThe University Arizona).

PORRE, M. H.; ECK, T.P.; SWINGLE, R.S.; THEUREN, C.B. Total starch and relative starch availability of feed grams. In: BIENAL CONFERENCE ON RUMEN FUNCTION. 20., Chicago, 1989. Abstracts. Chicago, 1989. p. 35.

RODRIGUEZ, N. M.; SAAD, C.E.P; OLIVEIRA, H.P. Degradabilidade ruminal do farelo de soja sob dois níveis de concentrado. In: REUNIÃO ANUAL DA SOCIEDADE BRASILEIRA DE ZOOTECNIA, 28., João Pessoa, 1992. Anais. João Pessoa, SBZ, 1991. p.206.

ROE, M.B.; CHASE, L.E.; SNIFFEN, C.J. Comparasion of "in vitro" to the "in situ" tecnique for estimation of ruminal degradation of protein. Joumal of Dairy Science, Champaign, 74(5):1632-40, 1991.

RUSSEL, J.B.; O'CONNOR, J.D.; FOX, D.G.; VAN SOEST, P.J.; SNIFFEN, C.J. A net carbohydrate and protein evaluating cattle diets. I. Ruminal fermentation. Joumal of Animal Science, Champaign, 70(11): 3551-61, 1992.

SAMPAIO, I.B.M. Contribuições estatísticas e de técnica experimental para ensaios de degradabilidade de forragens quando avaliada "in situ"In: SIMPÓSIO INTERNACIONAL DE PRODUÇÃO DE RUMINANTES; REUNIÃO ANUAL DA SOCIEDADE BRASILEIRA DE ZOOTECNIA, 31., Maringá, 1994. Anais. Maringá, SBZ, 1994. p.119-33.

SCHALCH, E \& ANDRADE, P. Efeitos da composição de rações sobre a degradação ruminal de alimentos em bovinos e correlação com solubilidade. Revista da Sociedade Brasileira de Zootecnia, Viçosa, 21(2):250-61, 1992. 
SILVA, A.G. \& WANDERLEY, R.C Cinética da digestão ruminal de grãos de milho e soja. In: REUNIÃO ANUAL DA SOCIEDADE BRASILEIRA DE ZOOTECNIA, 29., Lavras, 1992. Anais. Lavras, SBZ, 1992a. p.136.

SILVA, A.G. \& WANDERLEY, R.C Degradabilidade dos farelos de algodão, soja e trigo no rúmen de vacas mestiças. In: REUNIÃO ANUAL DA SOCIEDADE BRASILEIRA DE ZOOTECNIA, 29., Lavras, 1992b. Anais. Lavras, SBZ, 1992b. p.137.

SMITH, L.W.; GOERING, H.K; GORDON, C.H. Relationships of forage compositions with rates of cell wall and indigestibility of cell walls. Joumal of Dairy Science, Champaign, 55(8):1140-7, 1972.

SNIFFEN, C.J., O'CONNOR, J.D., VAN SOEST, P.J., FOX, D.G., RUSSELL, J.B. A net carbohydrate and protein for evaluating cattle diets: II. arbohydrate and protein availability. Joumal of Animal Science, Champaign, 70(11): 3562-77, 1992.

SUSMEL, P.; STEFANON, B.; MILLS, C.R.; SPANGHERO, M. Rumen degradability of organic matter, nitrogen and fibre fractions in forages. Animal Production, London, 51(3): 515-26, 1990.

THIAGO, L.R.L.S. \& GILL, M. Consumo voluntánio: fatores relacionados com a degradação e passagem da fonagem pelo nímen. Campo Grande, EMBRAPA/ CNCPG, 1990. 65p.

THIAGO, L.R.L.S. Utilização da técnica de degradabilidade "in situ" para avaliação de forragens e alimentos concentrados. In: SIMPÓSIO INTERNACIONAL DE PRODUÇÃO DE RUMINANTES; REUNIÃO ANUAL DA SOCIEDADE BRASILEIRA DE ZOOTECNIA, 31., Maringá, 1994. Anais. Maringá, SBZ, 1994. p.89-93.

TRABALZA MARINUCCI, M.; DEHORITY B.A.; LOERCH, S.C. In vitro and in vivo studies of feeds in synthetic fiber bags. Joumal of Animal Science, Champaign, 70(1): 296-307, 1992. 
UDEN, P.; COLUCCI, P.E.; VAN SOEST, P.J. Investigation of chromium, cerium and cobalt as markes in digesta. Rate of passage studies. Joumal of the Science of Food and Agriculture, London, 31:625-32, 1980.

VALADARES FILHO, S.C. Utilização da técnica "in situ" para avaliação dos alimentos. In: SIMPÓSIO INTERNACIONAL DE PRODUÇÃO DE RUMINANTES; REUNIÃO ANUAL DA SOCIEDADE BRASILEIRA DE ZOOTECNIA, 31., Maringá, 1994. Anais. Maringá, SBZ, 1994. p.95-118.

VALADARES FILHO, S.C.; SILVA, J.F.C. da; SANT'ANNA, R.;VALADARES, R.F.D.; COELHO, H.A. Contaminação bacteriana em resíduos da incubação ruminal de alguns alimentos em sacos de náilon. Revista da Sociedade Brasileira de Zootecnia, Viçosa, 21(3):467-74, 1992.

VALADARES FILHO, S.; SILVA, J.F.C. da; LEÃO, M.I.; EUCLYDES, R.F.;VALADARES, R.F.D.; CASTRO, A.C.G. Degradabilidade "in situ" da matéria seca e proteína bruta de vários alimentos em vacas em lactação. Revista da Sociedade Brasileira Zootecnia, Viçosa, 19(6):512-22, 1990

VALADARES FILHO, S.C.; SILVA, J.F.C. da; LEÃO M.I.; EUCLYDES, R.F.; VALADARES, R.F.D.; CASTRO, A.C.G. Degradabilidade "in situ" da proteína bruta e matéria seca de alguns alimentos em vacas gestantes e lactantes. Revista da Sociedade Brasileira de Zootecnia, Viçosa, 20 (1): 111-22, 1991.

VAN SOEST, P.J.; ROBERTSON, J.B.; LEWIS, B.A. Methods for dietary fiber, neutral detergent fiber and nonstarch polysaccharides in relation to animal nutrition. Joumal of Dairy Science, Champaign, 74(9):1-15, 1991.

VARGA, G.A. \& HOOVER, W.H. Rate and extent of neutral detergent fiber degradation of feedstuffs in situ. Joumal of Dairy Science, Champaign, 66(10):2109-15, 1983.

VILELA, G.L. Degradabilidade "in situ" da matéria seca e da proteína bruta de vários alimentos em vacas alimentadas com diferentes rações. Viçosa, 1994. 68 p. (MS Universidade Federal de Viçosa). 
VON KEYSERLINGK, M. A. G. \& MATHISON, G.W. Use of the "in situ" technique and passage rate constants in predicting voluntary intake and apparent digestibility of forages by steers. Canadian Joumal Animal Science, Ottawa, 69(4): 973-87, 1989.

WANDERLEY, R.C; FONTES Jr., C; HUBER, J.T.; SIMAS, J. Efeito do método de processamento do grão na degradabilidade do amido do sorgo no rúmen de vacas leiteiras. In: REUNIÃO ANUAL DA SOCIEDADE BRASILEIRA DE ZOOTECNIA, 29., Lavras, 1992. Anais. Lavras, SBZ, 1992. p.164.

WANDERLEY, R.C.; HUBER, J.T.; WU, Z.; PESSARAKLI, M.; FONTES Jr, C. Influence of microbial colonization of feed particles on determination of nitrogen degradability by "in situ" incubation. Joumal Animal Science, Champaign, 71(11):3073-7, 1993.

WEAKLEY, D.C.; STERN, M.D.; SATTER, L.D. Factors affecting disappearance of feedstuffs from bags suspended in the rumen. Joumal Animal Science, Champaign, 56(2): 493-507, 1983.

WEISS, W.P.; CONRAD, H.R.; PIERRE, N.R.St. A theoretically-based model for predicting total digestible nutrient values of forages and concentrates. Animal Feed Science and Technology, Amsterdam, 39:95-110, 1992

WELCH, J.G. Physical parameters of fiber affecting passage from the rumen. Joumal of Dairy Science, Champaign, 69(10):2750-54, 1986.

WOHLT, J.E.; SNIFFEN, C.J.; HOOVER, W.H. Measurement of protein solubility in common feedstuffs. Joumal of Dairy Science, Champaign, 56(2):1052-8, 1973. 
Tabela 25. Frações solúvel (A), potencialmente degradável (B), indegradável (C) e taxa de degradação da fração potencialmente degradável (c) da matéria seca da silagem de milho, farelo de soja e sorgo grão, nas dietas avaliadas. Valores utilizados para calcular a degradabilidade efetiva da matéria seca considerando-se o tempo de colonização ("lag time").

\begin{tabular}{|c|c|c|c|c|c|c|c|c|}
\hline \multirow[b]{2}{*}{ Alimento } & \multicolumn{2}{|c|}{$A(\%)$} & \multicolumn{2}{|c|}{ B (\%) } & \multicolumn{2}{|c|}{$\mathrm{C}(\%)$} & \multicolumn{2}{|c|}{ c $(\% / \mathrm{h})$} \\
\hline & $\mathrm{D} 1$ & D2 & D1 & $\mathrm{D} 2$ & D1 & D2 & $\mathrm{D} 1$ & D2 \\
\hline Sil. de milho & 39,73 & 62,15 & 36,33 & 11,26 & 23,95 & 26,59 & 2,87 & 2,17 \\
\hline F.de soja & 74,05 & 71,69 & 24,98 & 25,43 & 0,85 & 2,64 & 7,98 & 6,67 \\
\hline Sorgo grão & 39,27 & 39,11 & 40,41 & 33,9 & 19,82 & 26,99 & 2,96 & 3,76 \\
\hline
\end{tabular}

D1: Dieta com $80 \%$ de volumoso e $20 \%$ de concentrado.

D2: Dieta com $60 \%$ de volumoso e $40 \%$ de concentrado.

Tabela 26. Frações solúvel (A), potencialmente degradável (B), indegradável (C) e taxa de degradação da fração potencialmente degradável (c) da proteína bruta da silagem de milho, farelo de soja e sorgo grão, nas dietas avaliadas.Valores utilizados para calcular a degradabilidade efetiva da proteína bruta considerando-se o tempo de colonização ("lag time").

\begin{tabular}{|c|c|c|c|c|c|c|c|c|}
\hline \multirow[b]{2}{*}{ Alimento } & \multicolumn{2}{|c|}{$\mathrm{A}(\%)$} & \multicolumn{2}{|c|}{ B (\%) } & \multicolumn{2}{|c|}{$\mathrm{C}(\%)$} & \multicolumn{2}{|c|}{ c $(\% / \mathrm{h})$} \\
\hline & D1 & D2 & D1 & D2 & D1 & D2 & Dl & $\mathrm{D} 2$ \\
\hline Sil. de milho & 70,12 & 71,46 & 28,78 & 27,48 & 1,10 & 1,07 & 2,94 & 3,41 \\
\hline F. de soja & 72,02 & 60,97 & 27,79 & 38,49 & 0,18 & 0,55 & 11,55 & 7,00 \\
\hline Sorgo grão & 27,33 & 30,32 & 69,70 & 66,23 & 2,97 & 3,46 & 2,57 & 3,17 \\
\hline
\end{tabular}

D1: Dieta com $80 \%$ de volumoso e $20 \%$ de concentrado.

D2: Dieta com $60 \%$ de volumoso e $40 \%$ de concentrado. 
Tabela 27. Frações solúvel (A), potencialmente degradável (B), indegradável (C) e taxa de degradação da fração potencialmente degradável (c) da fibra em detergente neutro da silagem de milho e farelo de soja, nas dietas avaliadas.Valores utilizados para calcular a degradabilidade efetiva da fibra em detergente neutro considerando-se o tempo de colonização ("lag time").

\begin{tabular}{|c|c|c|c|c|c|c|c|c|}
\hline \multirow[b]{2}{*}{ Alimento } & \multicolumn{2}{|c|}{ A (\%) } & \multicolumn{2}{|c|}{ B (\%) } & \multicolumn{2}{|c|}{ C (\%) } & \multicolumn{2}{|c|}{ c $(\% / h)$} \\
\hline & Dl & D2 & D1 & D2 & D1 & D2 & D1 & D2 \\
\hline Sil. de milho & 24,36 & 28,01 & 55,19 & 44,52 & 20,48 & 23,56 & 2,93 & 1,38 \\
\hline F. de soja & 29,06 & 36,18 & 65,90 & 57,18 & 5,08 & 6,65 & 13,17 & 10,55 \\
\hline
\end{tabular}

D1: Dieta com $80 \%$ de volumoso e $20 \%$ de concentrado.

D2: Dieta com $60 \%$ de volumoso e $40 \%$ de concentrado.

Tabela 28. Frações solúvel (A), potencialmente degradável (B), indegradável (C) e taxa de degradação da fração potencialmente degradável (c) do nitrogênio insolúvel em detergente neutro da silagem de milho e farelo de soja, nas dietas avaliadas. Valores utilizados para calcular a degradabilidade efetiva do nitrogênio insolúvel em detergente neutro considerando-se o tempo de colonização ("lag time").

\begin{tabular}{|c|c|c|c|c|c|c|c|c|}
\hline \multirow[b]{2}{*}{ Alimento } & \multicolumn{2}{|c|}{$A(\%)$} & \multicolumn{2}{|c|}{ B (\%) } & \multicolumn{2}{|c|}{$\mathrm{C}(\%)$} & \multicolumn{2}{|c|}{ c $(\% / \mathrm{h})$} \\
\hline & D1 & D2 & D1 & D2 & Dl & D2 & D1 & D2 \\
\hline Sil. de milho & 25,08 & 25,13 & 74,13 & 74,22 & 0,61 & 0,65 & 3,01 & 2.16 \\
\hline F. de soja & 0,00 & 0,00 & 99,46 & 98,63 & 0,53 & 1,37 & 9,63 & 7,49 \\
\hline
\end{tabular}

D1: Dieta com $80 \%$ de volumoso e $20 \%$ de concentrado.

D2: Dieta com $60 \%$ de volumoso e $40 \%$ de concentrado. 
Tabela 29. Frações solúvel (A), potencialmente degradável (B), indegradável (C) e taxa de degradação da fração potencialmente degradável (c) do amido da silagem de milho, farelo de soja e sorgo grão, nas dietas avaliadas.Valores utilizados para calcular a degradabilidade efetiva do amido considerandose o tempo de colonização ("lag time").

\begin{tabular}{|c|c|c|c|c|c|c|c|c|}
\hline \multirow[b]{2}{*}{ Alimento } & \multicolumn{2}{|c|}{ A (\%) } & \multicolumn{2}{|c|}{ B (\%) } & \multicolumn{2}{|c|}{$\mathrm{C}(\%)$} & \multicolumn{2}{|c|}{ c $(\% / \mathrm{h})$} \\
\hline & Dl & D2 & D1 & D2 & Dl & D2 & Dl & D2 \\
\hline Sil. de milho & 83.02 & 82.60 & 16.16 & 13.97 & 0.82 & 0.91 & 6.86 & 13.24 \\
\hline F. de soja & 77.92 & 84.05 & 21.83 & 16.05 & 0.37 & 0.12 & $\#$ & $\#$ \\
\hline Sorgo grão & 22.66 & 33.73 & 64.00 & 48.39 & 13.34 & 17.89 & 2.72 & 5.28 \\
\hline
\end{tabular}

D1: Dieta com $80 \%$ de volumoso e $20 \%$ de concentrado.

D2: Dieta com $60 \%$ de volumoso e $40 \%$ de concentrado.

\# Valores não calculados. 


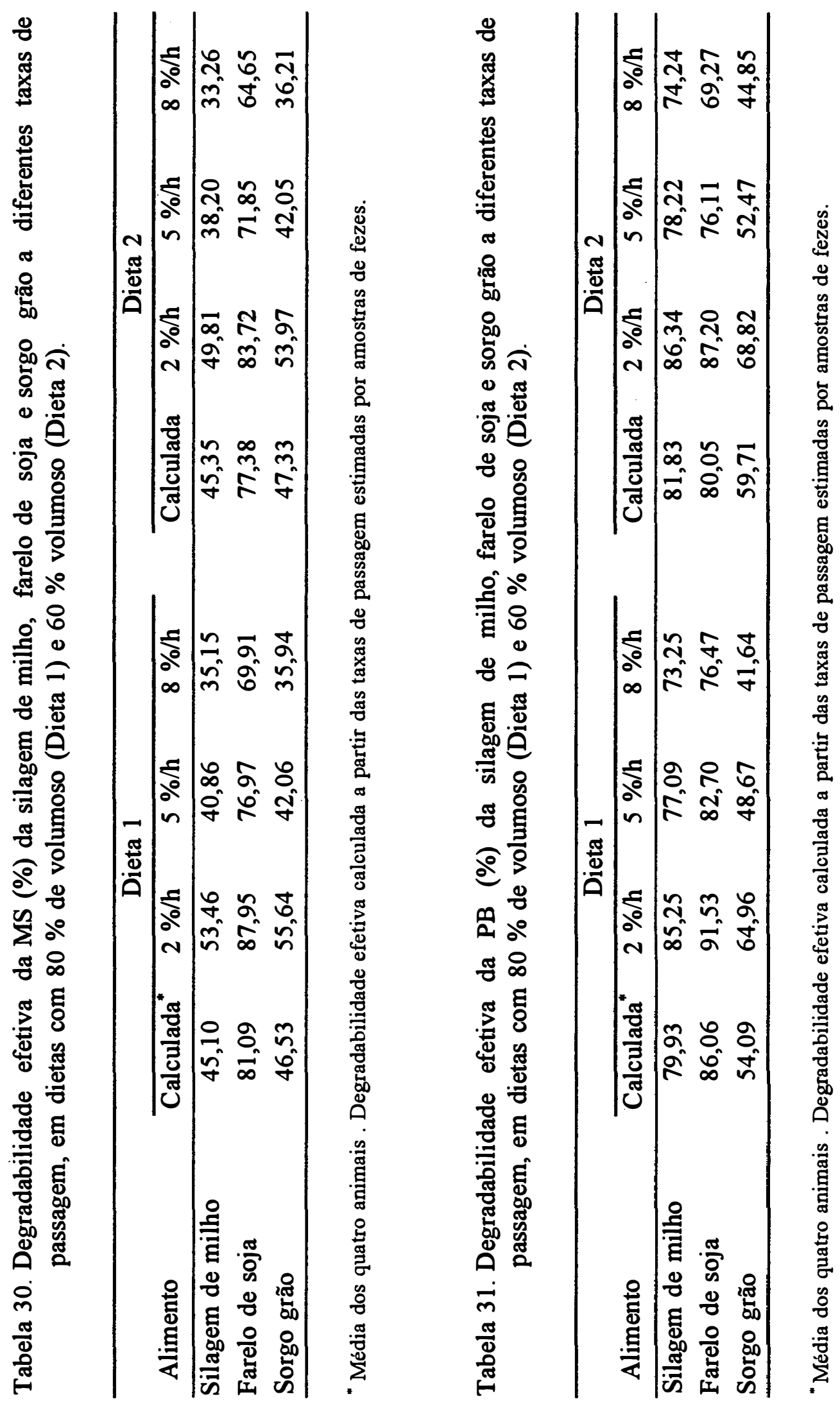




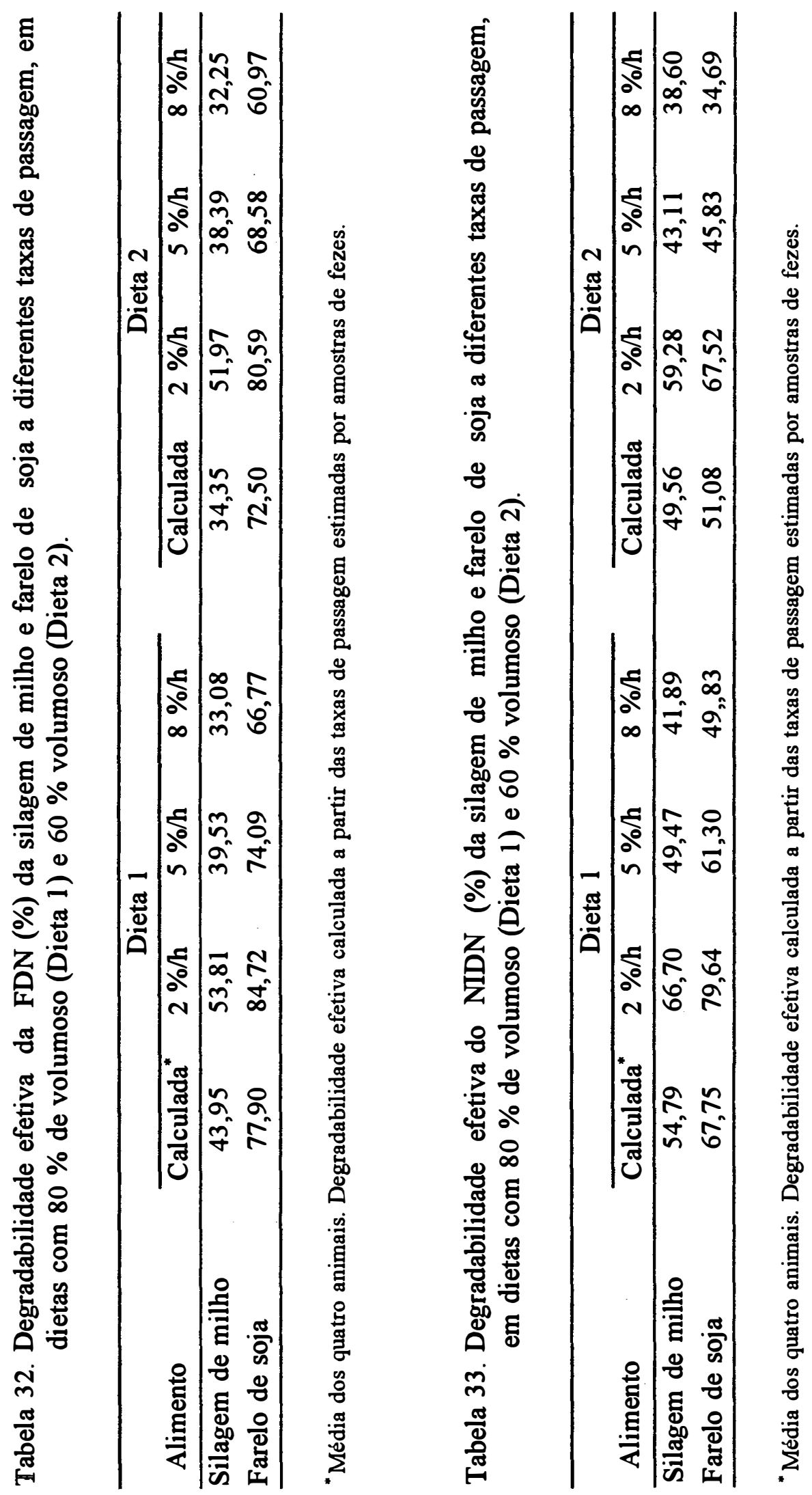




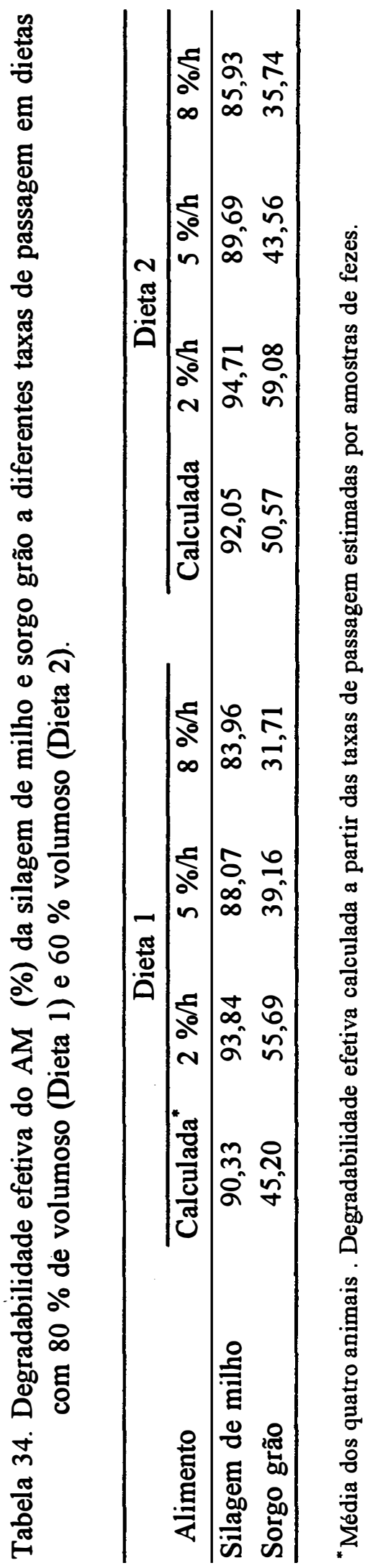


(5)

造

घี

웅

总

$\frac{\pi}{3}$

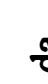



:
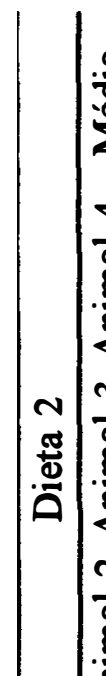

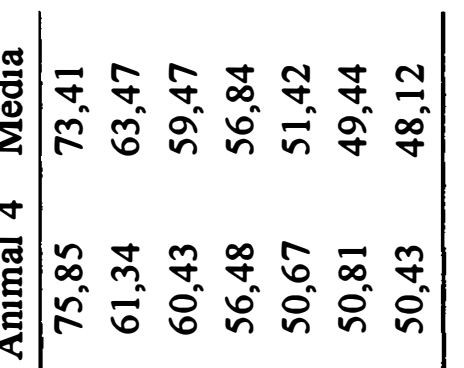

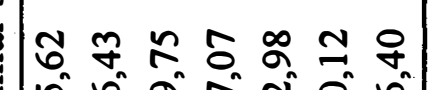

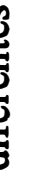

音

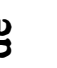

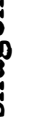

$\sum^{n}$

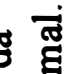

올 즐

농

灾

蛋

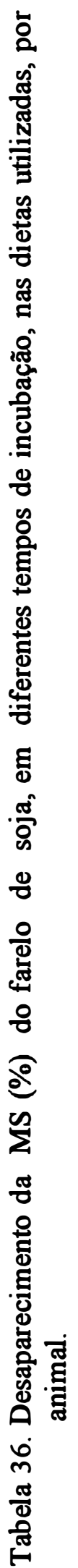

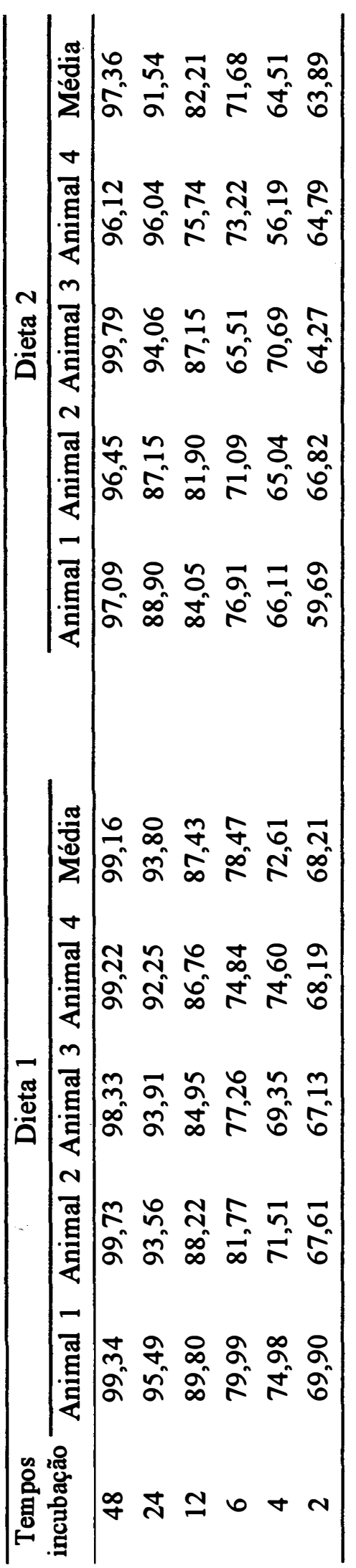




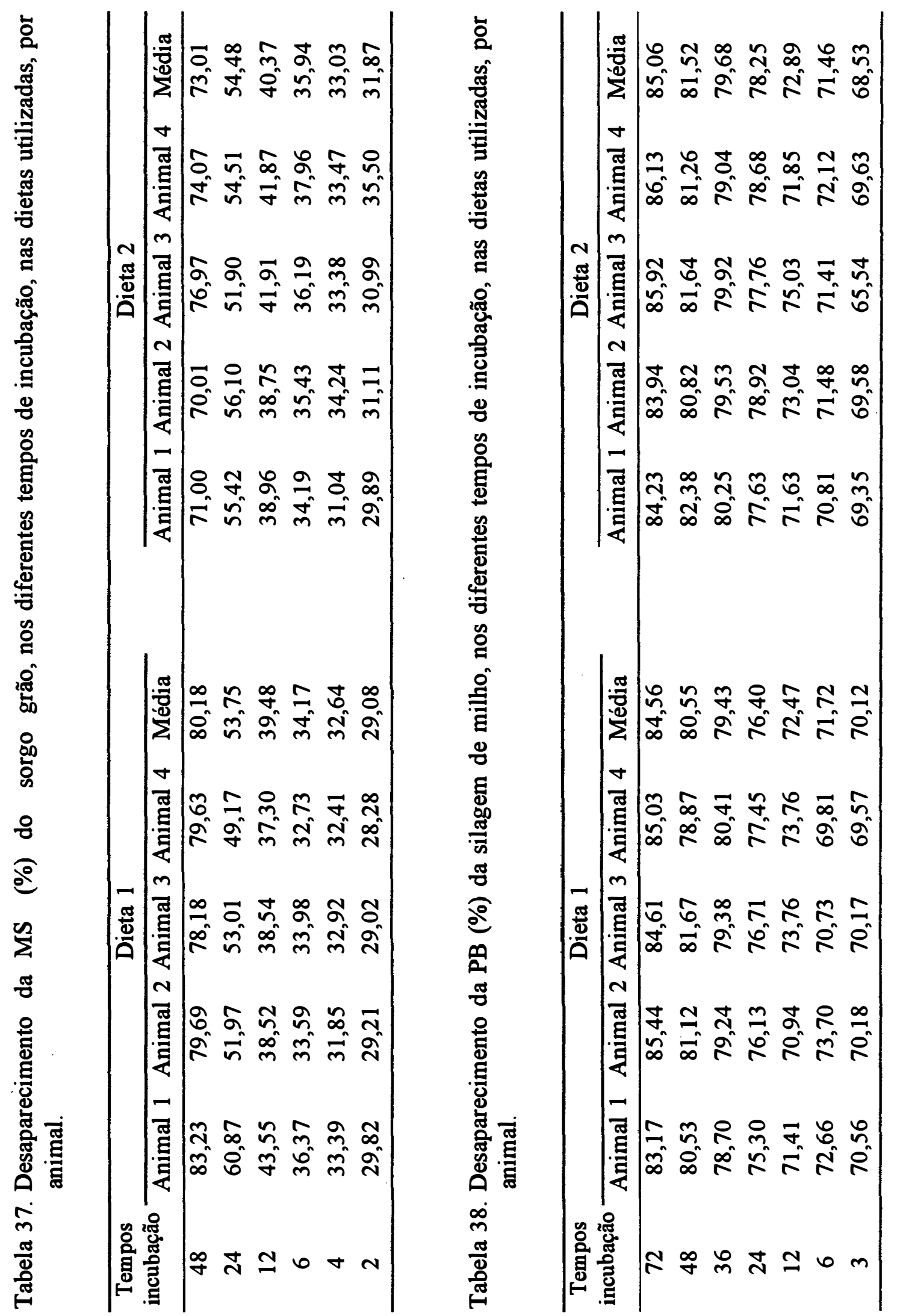



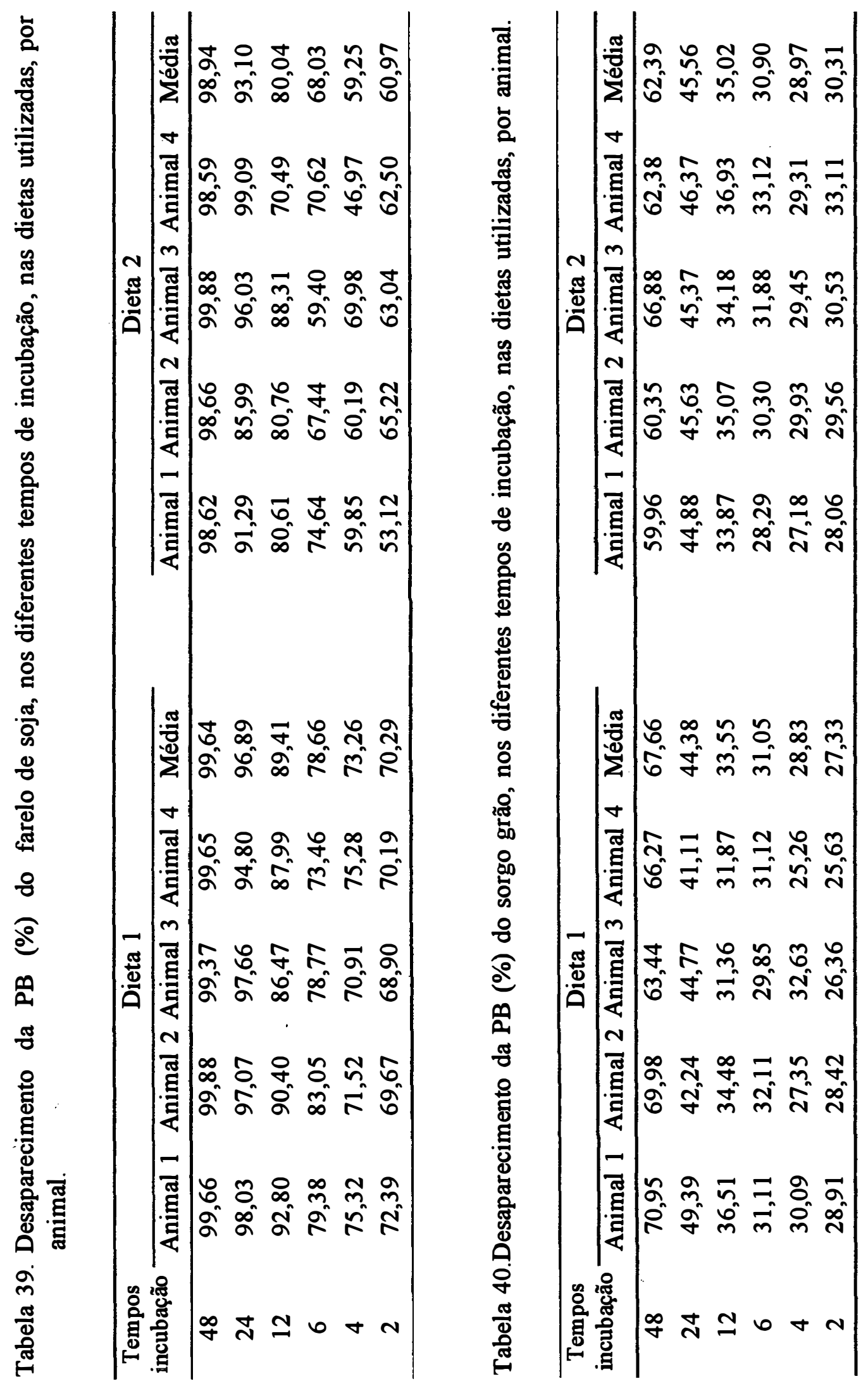


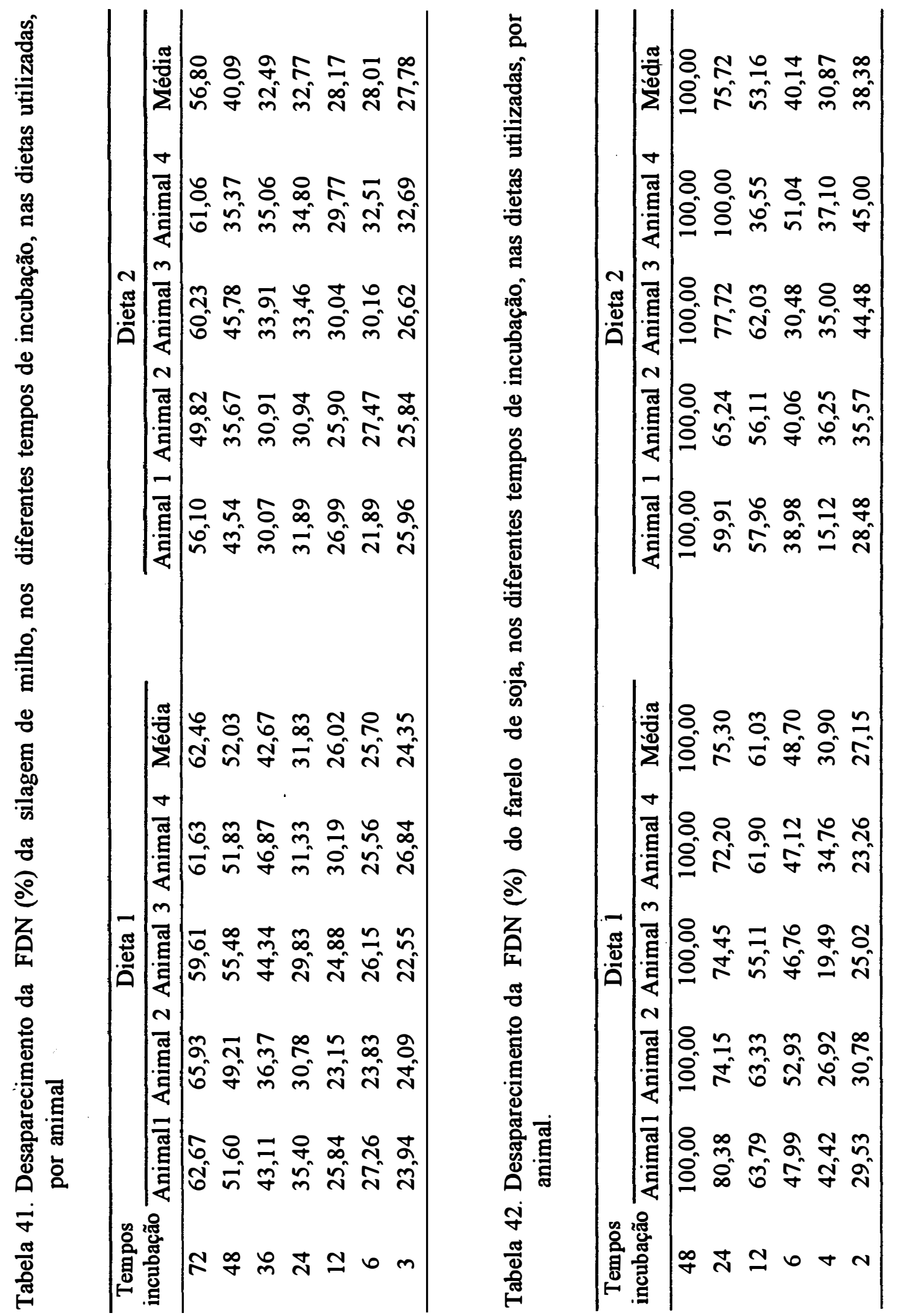




\%

를

o

离

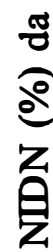

웅

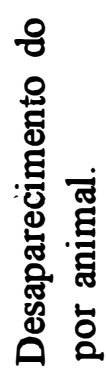

$\dot{q}$

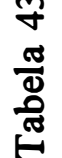

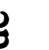

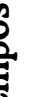

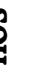

$\stackrel{8}{g}$

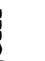

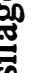

8

d

㝵

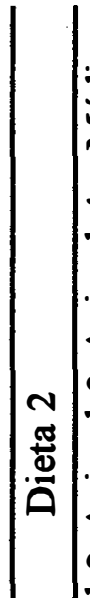

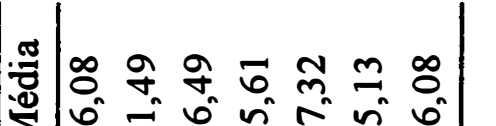

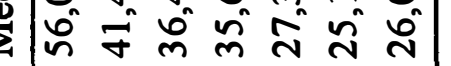
$\forall$

|

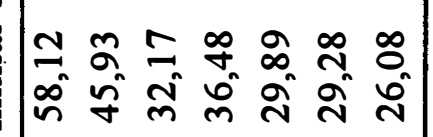

败 유

倦

สี

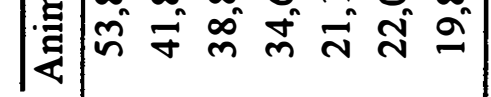

里

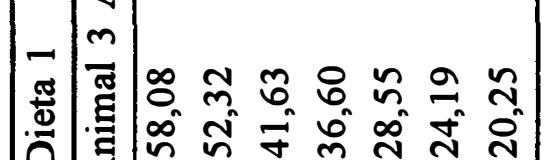

$m$ 은

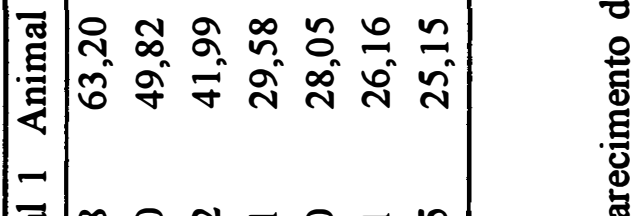

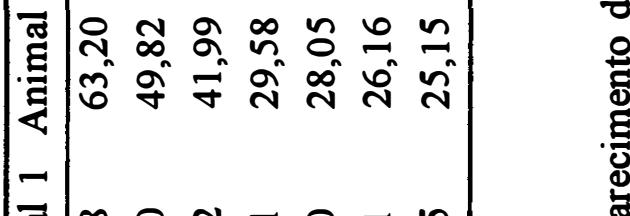

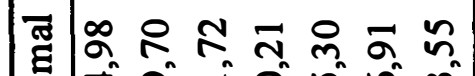

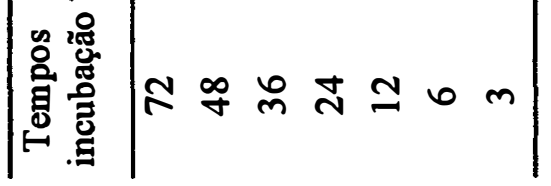

:

:

. कृ

ช

응

응

d

量

응

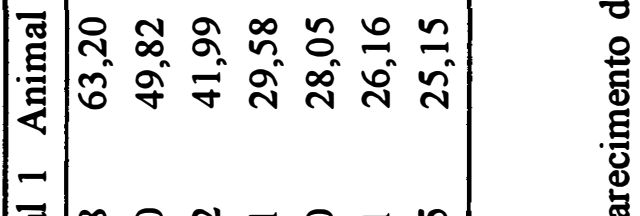

苋

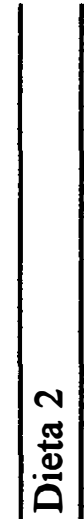

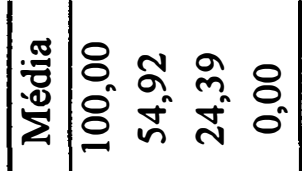

$\nabla$

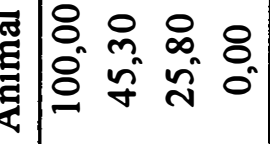

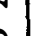

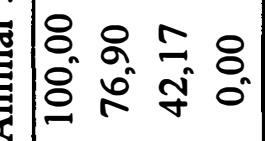

N

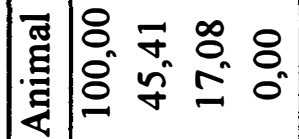

寸

离

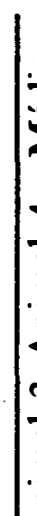

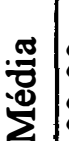

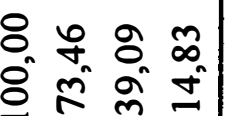
$\nabla$

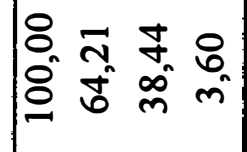

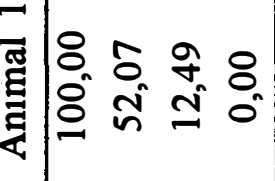

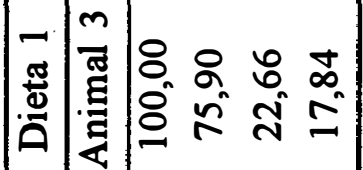

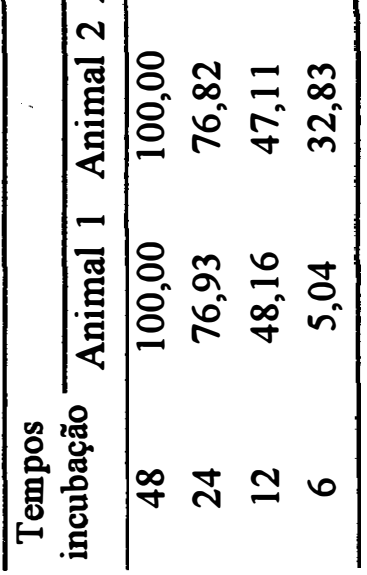




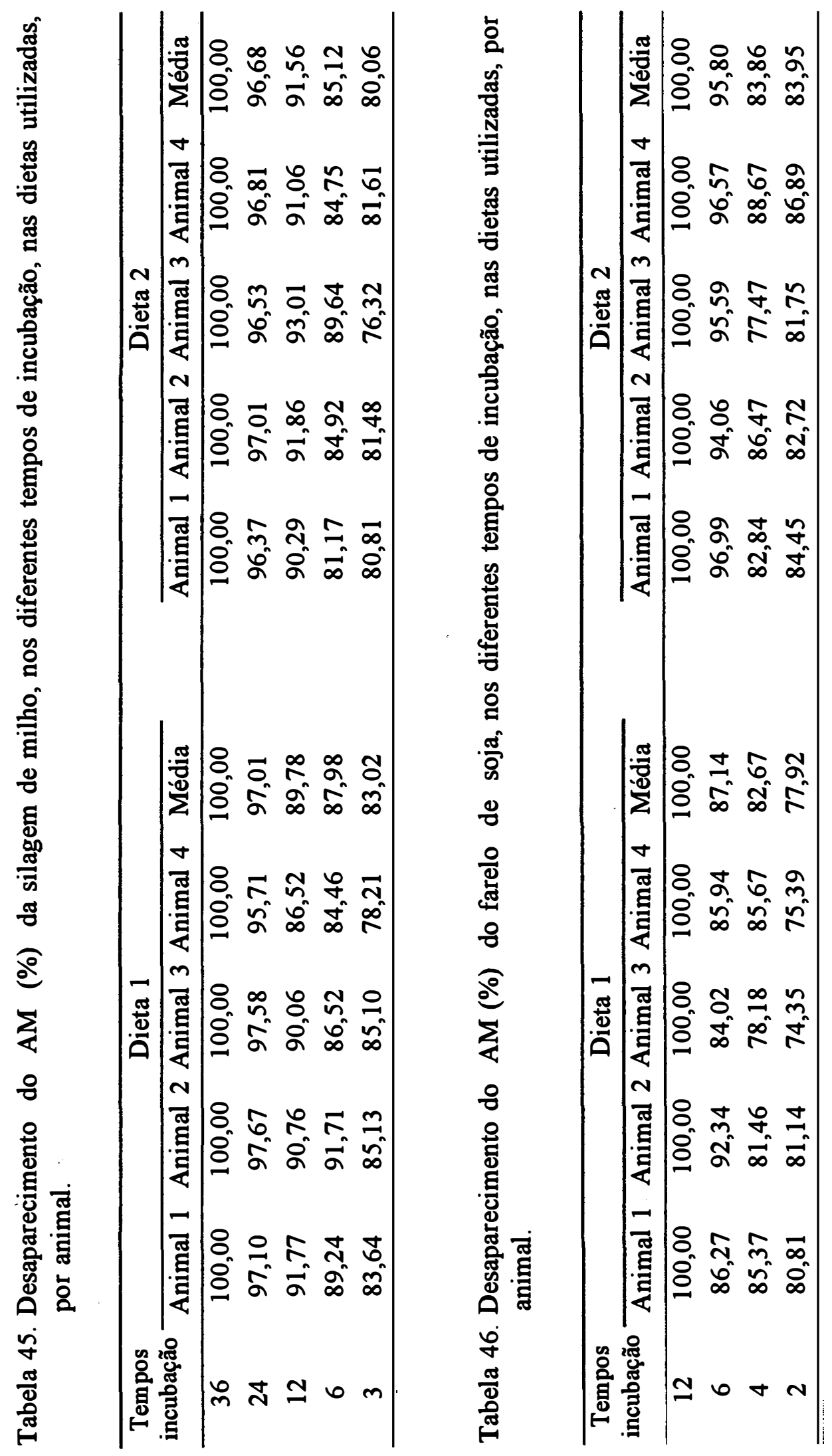




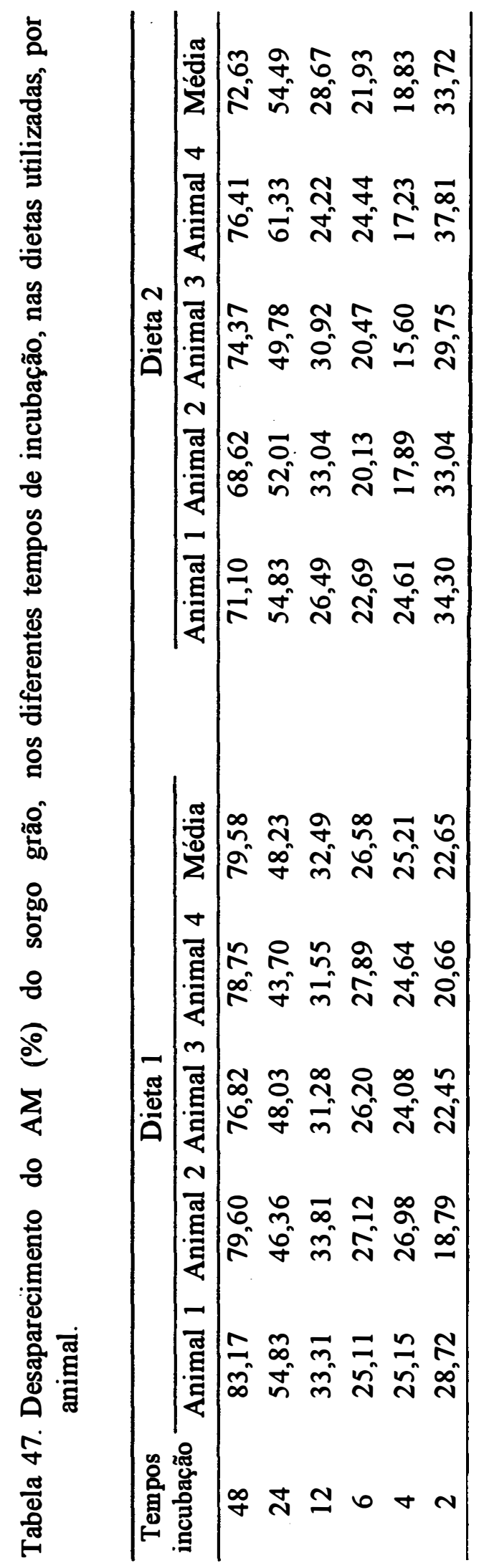

